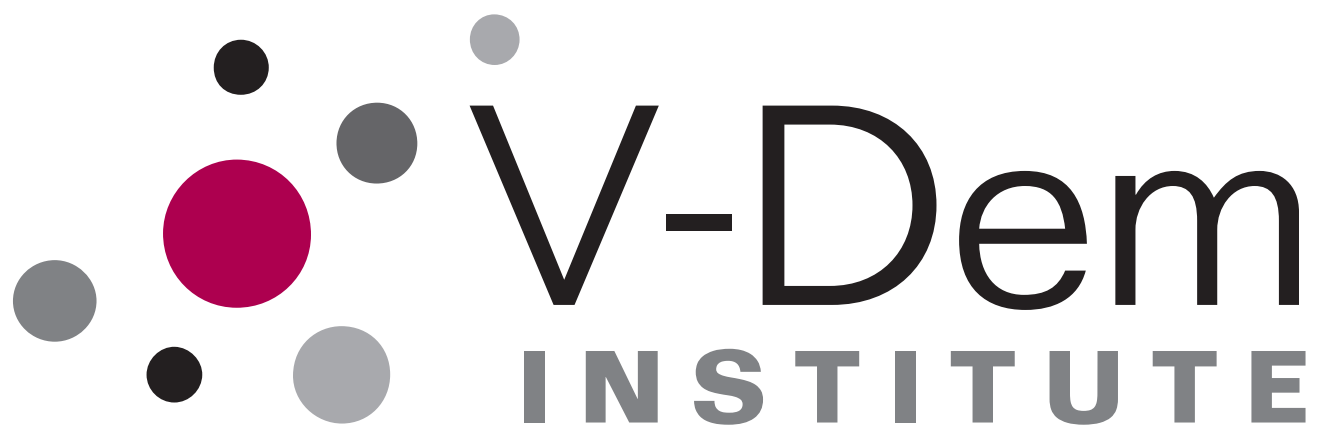

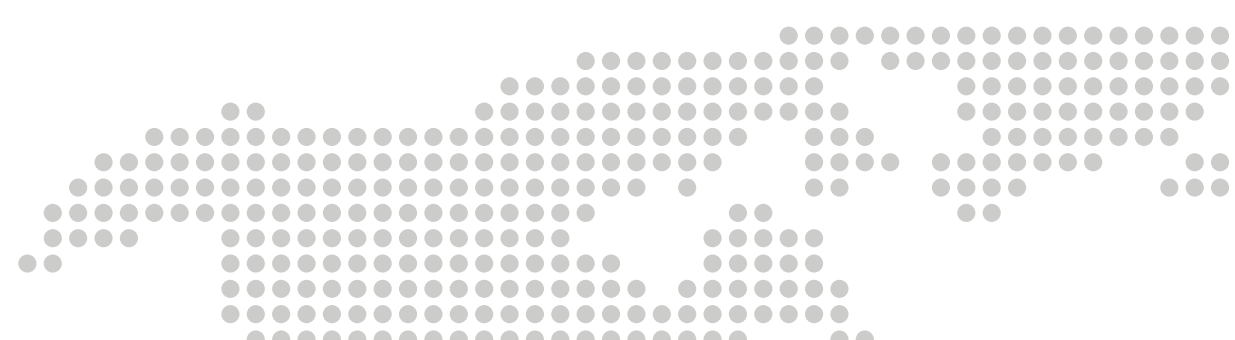

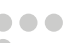

.

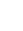 ○. 100

$$
\begin{array}{rr}
0000 \\
00000
\end{array}
$$

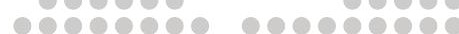

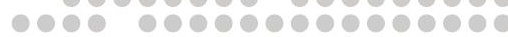

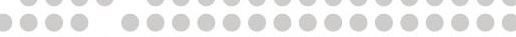

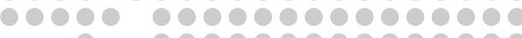
0 000000000000000 $000000000000000000 \mathrm{c}$ 2000000000000000000000 100000000000000000

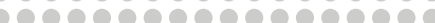

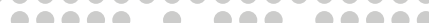
1000

Patterns of Regime Breakdown since the French Revolution

Vilde Lunnan Djuve, Carl Henrik Knutsen, and Tore Wig

100

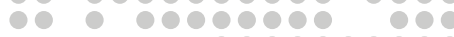

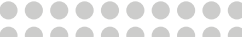

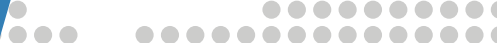

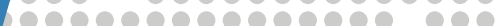
10000000000

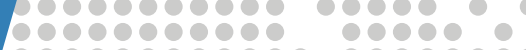

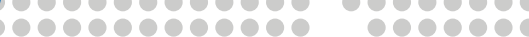

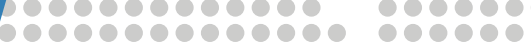

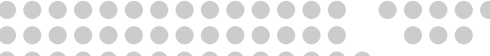

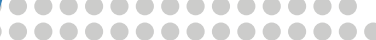
10000000000000000000

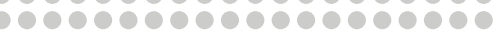
10000000000000000

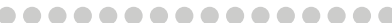

10000000000000

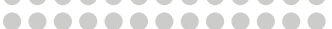

10000000000

0000000000

000000000

o

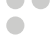

000000000

0009800

000000

090000

1000

000

100

10

10

00

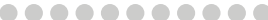

90900000000

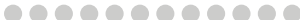

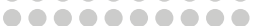

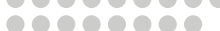

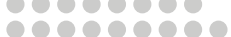

000000

100000

000000

000

100 
Varieties of Democracy ( $\mathbf{V}-$ Dem) is a new approach to conceptualization and measurement of democracy. The headquarters - the V-Dem Institute - is based at the University of Gothenburg with 17 staff. The project includes a worldwide team with six Principal Investigators, 14 Project Managers, 30 Regional Managers, 170 Country Coordinators, Research Assistants, and 3,000 Country Experts. The V-Dem project is one of the largest ever social science research-oriented data collection programs.

Please address comments and/or queries for information to:

$\mathrm{V}$-Dem Institute

Department of Political Science

University of Gothenburg

Sprängkullsgatan 19, PO Box 711

SE 40530 Gothenburg

Sweden

E-mail: contact@v-dem.net

V-Dem Working Papers are available in electronic format at www.v-dem.net.

Copyright (C) 2018 by the authors. All rights reserved. 


\title{
Patterns of Regime Breakdown since the French Revolution
}

\author{
Vilde Lunnan Djuve ${ }^{1}$, Carl Henrik Knutsen ${ }^{2}$, and Tore $\mathrm{Wig}^{2}$ \\ ${ }^{1}$ Department of Political Science, Aarhus University \\ ${ }^{2}$ Department of Political Science, University of Oslo
}

June 28, 2018

\begin{abstract}
We present a new dataset comprising more than 1900 regimes in 197 polities over the time period 1789-2016. We use this dataset to describe different historical patterns of regime duration globally, leveraging fine-grained measures on when regimes started and ended and a nuanced scheme of different modes of regime breakdown. To mention a few patterns, we display how the frequency of regime breakdown, and particular modes of breakdown, have followed cyclical rather than linear patterns across modern history and that the most common modes, overall, are coups d'état and incumbent-guided transformations of regimes. Further, we evaluate whether selected economic and political-institutional features are systematically associated with breakdown. We find robust evidence that low income levels, slow or negative economic growth, and having intermediate levels of democracy predict higher chances of regime breakdown, although these factors are more clearly related to regime breakdown during some periods of modern history than others. When disaggregating different models of breakdown, we find notable differences for these predictors, with low income levels, for example, being strongly related to regime breakdowns due to popular uprisings, whereas intermediate levels of democracy clearly predict regime breakdowns due to coups and incumbent-guided regime transitions.
\end{abstract}

* We thank Haakon Jernsletten, Konstantinos Skenteris, Katharina Sibbers, Bernardo Isola, Ida Smedstad, Solveig Bjørkholt, and Sindre Haugen for excellent research assistance. We are grateful for valuable comments and inputs, at various stages in the process, from Jan Teorell, Svend-Erik Skaaning, Haakon Gjerløw, Agnes Cornell, John Gerring, Andrej Kokkonen, Joe Wright, Espen Geelmuyden Rød, as well as participants at the 2017 APSA Annual Meeting in San Francisco, the "State-Building and Regime Change in a Historical-Political Science Perspective Workshop" at Aarhus University, the "Autocratic Diversity Workshop" at Aarhus University, the "Historical Varieties of Democracy Workshop" at the University of Oslo, The Departmental Speaker Series Seminar, November 27, 2017, at the Department of Government, University of Essex, and the "The Empirical Study of Autocracy Workshop" at University of Konstanz. This data collection and research project was mainly funded by the Research Council Norway, "Young Research Talent" grant, pnr 240505, PI: Carl Henrik Knutsen, but also by a "2016 Småforsk Grant" from the Department of Political Science, University of Oslo, PI: Carl Henrik Knutsen, and by Riksbankens Jubileumsfond, Grant M13-0559:1, PI: Staffan I. Lindberg, V-Dem Institute, University of Gothenburg, Sweden. 


\section{Introduction}

All political regimes eventually die, but they do so in very different ways. Some regimes undergo self-imposed change and transform into something else "from the inside". Examples are autocratic regimes liberalizing to become democracies or democratically elected presidents conducting self-coups. Other regimes are terminated by outside forces. Examples are popular protests setting off a revolution, military officers coordinating a coup d'état, or a foreign power intervening and forcing out the incumbent regime.

Understanding such processes of regime breakdown and change has long been a core concern of social scientists (early contributions include Davies, 1962; Gurr, 1970; Lipset, 1959; Moore, 1966). While data from the post-WWII era suggest that a minority of regime breakdowns were followed by democratization (Geddes, Wright and Frantz, 2014), the contemporary literature places a special focus on such regime changes (e.g., Coppedge, 2012; Teorell, 2010). Yet, democratic breakdowns (e.g., Svolik, 2008) and transitions between different types of autocracies (e.g., Hadenius and Teorell, 2007) have also received attention. Further, distinct literatures address particular processes of regime breakdown, such as popular revolutions (e.g., Chenoweth and Stephan, 2011) and coups d'état (e.g., Powell, 2012). Regarding the potential determinants of regime breakdown, some studies highlight structural factors, such as (various) regime-type characteristics (c.f. Gates et al., 2006; Geddes, 1999), poverty (Przeworski and Limongi, 1997), and natural resource abundance (Ross, 2012). Other studies highlight "trigger" factors - events that disrupt previous equilibria and prompt regime opponents to mobilize against the regime - including elections (e.g., Knutsen, Nygård and Wig, 2017), international wars (Bueno de Mesquita, Siverson and Woller, 1992), and economic crises (e.g., Przeworski and Limongi, 1997).

Despite all the attention given to regime breakdown (and change) our cumulative understanding of this key phenomenon has been restricted by the following features: 1) Extant studies often circumscribe their focus to consider particular types of transitions, notably democratization. 2) Most studies have a restrictive scope, mainly focusing on decades after WWII - a relatively short period of "modern history". Even within this time-frame, studies suggest that both the causes (Ross, 2012) and main modes (Kendall-Taylor and Frantz, 2014) of regime breakdown may have shifted. While there are benefits to studying a more homogeneous set of cases, we thus run the risk that our knowledge claims about regime breakdown and change, based on post-WWII data, may be less robust (Knutsen, Møller and Skaaning, 2016) or have less general applicability (Boix, 2011) than is commonly supposed.

We present a new dataset that may help alleviate these limitations. The "Historical 
Regime Data" (HRD) includes measures on the identity, time period of existence, and mode of breakdown for more than 1900 regimes. HRD spans most large polities, globally, after the French revolution, documenting the life-cycles of regimes at a high level of temporal precision. HRD is nested into the larger Historical Varieties of Democracy (HVDEM) dataset (Knutsen

et al., 2017) - which contains several hundred indicators that can easily be mapped on to the identified regimes to carefully describe their institutional make-up and evolution - and thus covers the 91 countries, semi-autonomous polities and colonies in Historical V-Dem from 1789-1920. Further, HRD covers all polities covered by V-Dem v.7 (Coppedge et al 2017a) from 1900 onwards. Thus, HRD includes data for 197 polities with some time series running from 1789-2016.

In the following, we fist elaborate on the concepts of 'political regime' and 'regime breakdown', outlining our definitions and key alternatives. We then discuss key issues and operational rules for identifying regimes and breakdowns. Next, we describe and illustrate the specific variables contained in $\mathrm{HRD}$, before we use the data to map patterns of regime breakdown across modern history. After that, we review extant literature on three proposed determinants of regime breakdown - level of democracy, income level, and short-term economic growth - before we present our empirical results. To quickly preview a few findings, regimes with a mix of democratic and autocratic features are significantly more prone to break down than full democracies and autocracies, and high income levels and high shortterm growth seem to inoculate regimes from breakdown. Also when considering various modes of breakdown, these factors often (though far from always) turn up as key predictors. Further, we run change-point models to identify time periods with relatively frequent and infrequent regime changes, and assess the relevance of the mentioned predictors in different time periods. Democracy level, income level, and short-term growth are especially clearly related to regime breakdown from the start of WWI to a few years after the Cold War ended, a period of modern history characterized by frequent regime changes.

\section{Political regimes and regime breakdown: Conceptu- alization and operational issues}

We define a 'political regime' as the set of rules that are essential for selecting political leaders, and for maintaining them in power. These can be formal rules, for instance embedded in constitutions, but also informal rules and practices, enforced by a broader or narrower group of people. Thus, a regime is typically characterized by it determining who selects policies, 
and, in extension, often also how these policies are typically selected. One key benefit of this definition, which closely follows that of Geddes (1999), is that it allows for capturing multiple, relevant instances of changes to a country's political system. When relying on this definition, we need not limit ourselves to capturing only one particular type of regime change, such as "democratic transitions".

We highlight that formal and informal rules for determining political leaders often coexist. If the formal and informal rules correspond - i.e., the formal rules are followed stability in the formal rules can be used to identify a regime. This situation is common in modern democracies with a strong rule of law. In these instances, evaluating continuation of key formal rules - for example as written in the constitution - provide clear operational criteria for judging the regime's continued existence. If, however, the formal and informal rules for selecting and maintaining leaders do not correspond, such as in many dictatorships, the informal rules take precedence when identifying a regime as they de facto determine who selects policies. To exemplify, if the constitution stipulates that leaders are elected through multi-party elections, but leaders were, in fact, selected through a military coup and maintained by a coalition of military officers, the latter features determine the regime, according to our definition. We elaborate on specific, operational issues for identifying regimes below, but first provide a contrast with alternative notions of regimes and regime change.

\subsection{Alternative notions and measures of regime change}

Table 1 illustrates that there are multiple ways to define what constitutes a regime or regime change. One common alternative in the political science literature is to invoke the distinction between democracies and autocracies, and define regime change (only or mainly) according to substantial changes along this dimension (e.g., Cheibub, Gandhi and Vreeland, 2010; Marshall, Gurr and Jaggers, 2013). Degree of democracy is critically associated with the formal rules through which leaders are selected and deposed, such as the existence of multiparty elections and universal franchise. But, most scholars acknowledge that also informal rules and practices matter for democracy, for example pertaining to whether elections are conducted freely and fairly or if elections are associated with some kind of fraud - not described in the constitution - that determines outcomes.

While not restricted to considering these elements pertaining to democracy, our preferred regime definition encapsulates such elements, and thus allows us to capture regime changes 
Table 1: Regime datasets with global coverage

\begin{tabular}{|c|c|c|c|c|}
\hline Dataset & Time period & Granularity & Regime-change type & Definition \\
\hline HRD & $1789-2016$ & Day & All regime changes & $\begin{array}{l}\text { Informal and formal } \\
\text { rules for maintaining power }\end{array}$ \\
\hline Geddes, Wright and Frantz (2014) & 1946-2012 & Day & $\begin{array}{l}\text { All regime changes, } \\
\text { focused on between-type }\end{array}$ & $\begin{array}{l}\text { Informal and formal } \\
\text { rules for maintaining power }\end{array}$ \\
\hline Hadenius and Teorell (2007) & $1972-2014$ & Year & Regime type-based & $\begin{array}{l}\text { Institutional modes of leader selection } \\
\text { (Military, hereditary, electoral) }\end{array}$ \\
\hline Boix, Miller and Rosato (2013) & $1900-2012$ & Year & Regime type-based & Democracy-Autocracy \\
\hline Cheibub, Gandhi and Vreeland (2010) & 1946-2008 & Year & Regime type-based & Democracy-Autocracy, with sub-types \\
\hline Svolik (2012) & 1946-2008 & Year & Regime type-based & Authoritarian spells (vs. democracy, no authority) \\
\hline Marshall, Gurr and Jaggers (2013) & $1800-2015$ & Year & Movements "democracy scale" & $\begin{array}{l}3 \text {-point change Polity score (in three years or less) } \\
\text { or end of transition period }\end{array}$ \\
\hline
\end{tabular}

stemming from substantial changes to, e.g., electoral practices. ${ }^{1}$ But, critically, our definition also allows us to capture other regime breakdowns and subsequent changes, including changes between regimes that are equally (un)democratic. To exemplify, our definition covers changes between a harshly repressive one-party state, where party bosses select leaders through some formal or informal process, and an about equally repressive absolutist monarchy, where particular rules of dynastic succession determine leader selection. It also covers changes between two military regimes (i.e., regimes belonging to the same "autocracy type") with distinct military juntas operating different informal rules for selecting the leadership.

Extant datasets with global coverage that identify regimes or regime change include, but are not restricted to, Cheibub, Gandhi and Vreeland (2010), Boix, Miller and Rosato (2013), Hadenius and Teorell (2007), Svolik (2012), Geddes, Wright and Frantz (2014), and (Marshall, Gurr and Jaggers, 2013). Table 1 provides an overview of the temporal and spatial scope of these widely used datasets, and their temporal granularity (i.e. whether regime changes are coded at the level of years or days). The table also describes the type of changes considered to be regime changes, roughly distinguishing between "type-based" changes (i.e., where the regime has to change from one regime type to another to constitute a regime change) and regime changes that do not hinge on change in type ("all regime changes"). Most "type-based" datasets rely on some version of the above-described democracy-autocracy distinction for identifying regimes, whereas Hadenius and Teorell (2007) relies on the different institutional modes of selecting leaders (military, hereditary, electoral) for identifying (authoritarian) regimes. Since we maintain that regime change can occur also between regimes that are commonly classified as belonging to the same type, our HRD dataset thus includes more regime changes than these datasets focusing only on type-based transitions. HRD is

\footnotetext{
${ }^{1}$ We highlight that regular government changes in democracies following an incumbent loss in free and fair elections are not counted as regime changes.
} 
most closely related to the Geddes et al. dataset (henceforth "GWF") in terms of conceptualization and delineating political regimes, though there are notable differences. Given this, but also because Geddes, Wright and Frantz (2014) carefully compare GWF with the other widely used datasets listed in Table 1, we focus our discussion on similarities and contrasts between HRD and GWF.

One notable difference between GWF and HRD is that the former - while remaining open to including clear instances of change between regimes of identical type - takes transitions between its own categories of autocratic regime types (military, dominant party, personalist, etc.) as a key point of departure when looking for regime change. HRD does not operate with a clear categorization of "types" as its basis for identifying regime changes. Instead, we take the broader question of identifying when the formal or informal rules for selecting and maintaining leaders are substantially altered as our point of departure, and develop a large set of heuristics for identifying changes to these rules (in a manner that is consistent across countries and time). These heuristics were used in conjunction with a thorough reading of secondary sources to delineate regime units and determine the dates of regime births and deaths directly.

As Geddes, Wright and Frantz (2014) point out, there is a tradeoff between using simple coding rules and the reliability that they bring versus the ability to capture complex concepts such as regime breakdown in a valid manner. Whereas clear, objective rules may increase replicability, they may also disregard nuance and risk imprecision. HRD emphasizes the latter half of this tradeoff to an even greater extent than GWF (and much more so than, for example, Cheibub, Gandhi and Vreeland (2010)), but also seeks to ensure replicability and transparency through providing detailed notes justifying each coding decision alongside lists of sources used for the coding. Prioritizing the ability to capture various kinds of regime change and dispensing with a restrictive set of "sharp rules" becomes even more important because of the extensive time period HRD covers. Whereas GWF starts in 1946, HRD extends back to 1789, increasing the heterogeneity of regimes and changes covered.

Let us, however, illustrate the benefits of our approach by using a more recent case, included also in GWF, namely Reza Shah's Iran (see Figure 1 for coding timelines). GWF codes Iran as having a single regime from 1925 to the Shah's flight in 1979. In HRD, this regime spell - which is coded to start, more precisely, on December 15, 1925 - is broken up by both the 1941 Anglo-Soviet invasion (November 16) and the coup of August 19, 1953. Though accounts disagree on, e.g., the importance of CIA interference in the 1953 coup, several scholars agree on the coup's significance for how Iran was governed in practice 
Historical Regimes Data

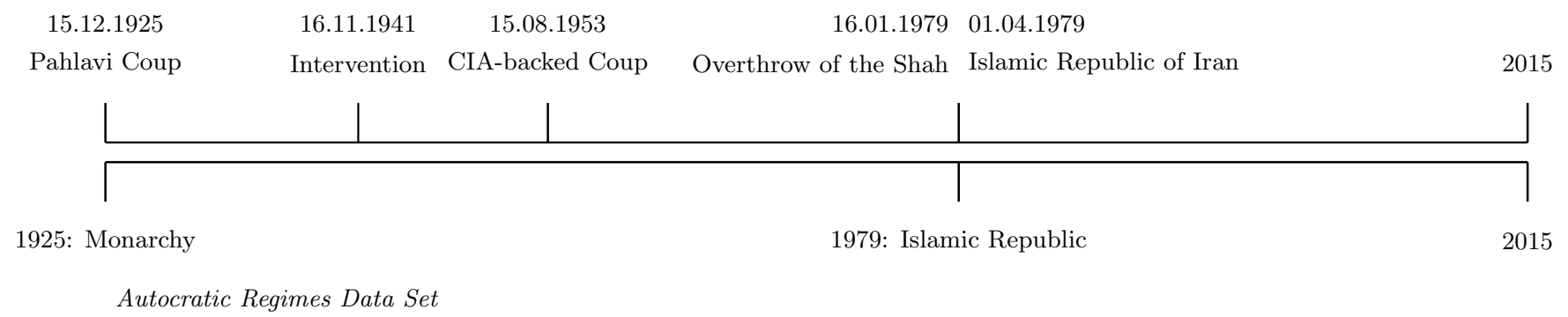

Figure 1: Timeline of Regimes in Iran: Comparison of HRD (top) and GWF (bottom) coding, $1925-2015 .^{2}$

(Gasiorowski, 1987; Gasiorowski and Byrne, 2004; Abrahamian, 2013; Takeyh, 2014; Zahrani, 2002). Gasiorowski $(1987,1)$, for example, notes that the "government of Prime Minister Mohammad Mosaddeq which was ousted in the coup was the last popular, democratically oriented government to hold office in Iran." In this instance, we therefore consider that the nature of the pre-coup regime, including an actual elected Prime Minister functioning far beyond nominal status, is so different from the ensuing post-coup personal monarchy that the two should not be regarded a single regime defined by the Shah's rule, even if the monarchy, as such, persists.

More generally, HRD applies lower thresholds for coding regime deaths than GWF, mostly resulting from a more inclusive notion of what to count as a "substantial" change in rules for selecting political leaders. Hence, across the overlapping country-years where Geddes et al. count 280 autocratic regimes and 207 democratic episodes, HRD contains 925 regimes. We emphasize that transitional regimes are important to count as separate regime spells (e.g., in order not to overestimate regime duration). Again, the HRD coding of Iran serves as a good example. When the Shah's regime is, eventually, toppled by the clergy and Ayatollah Khomeini in 1979, there is a period of confusion between the Shah's flight on January 16 and the declaration of the Islamic Republic on April 1. In this period, the Regency Council attempts to rule in the Shah's absence (Rubinstein, 1981), separating it from the consolidated Khomeini rule beginning in April.

\footnotetext{
${ }^{2}$ In Svolik (2012), HRD's regime change events are recorded as leadership change, but the entirety of the period is coded as one single authoritarian spell.
} 


\subsection{Operational criteria for identifying regimes in HRD}

While our definition opens up for a comprehensive and fine-grained account of countries' regime histories, it also presents several operational challenges. How do we judge whether a rule change is substantial, and thus sufficient for constituting regime change? Further, how do we ensure that we capture substantial changes to informal rules, which are inherently hard to observe. We devised several strategies in response to these challenges, constructing several heuristics for identifying substantial rule changes and for coding regime breakdowns consistently across time and space. While the bulk of discussion is presented in the online appendix - with a particular focus on how we coded particularly difficult cases pertaining to self-coups and other incumbent-guided regime transitions, cases of de-colonization, and cases where a polity splits up into several entities - we briefly discuss some key issues here.

First, we note that our definition implies that vastly different processes can premeditate regime breakdown. These include, but are not restricted to, coups conducted by the military or other actors, self-coups conducted by sitting leaders, losses in civil war or inter-state war, popular uprisings, and substantial political liberalization with guidance by incumbents. These processes are covered in our 14-category mode of breakdown variable, and served as key markers for our coders when considering when a regime ended. Second, we identified other marque events, notably leadership changes, as candidates for further scrutiny. Sometimes, regime changes are related to government or leadership changes, such as the change in Zaire/DR Congo from the Mobutu- to the Kabila regime (see, e.g., Schatzberg, 1997). We immediately note that government or leadership changes do not necessarily bring regime changes, as exemplified by post-election government changes in democracies, or by the institutionalized changes to prime ministers and presidents in current China. We also note that regime changes can take place without leadership changes, for example when military juntas institutionalize one-party rule.

But, for any potential candidate for regime breakdown, how did we identify whether a changes in rules and practices for selecting and maintaining leaders is substantial or not? Such changes can, of course, be relatively minor - think, for instance, of the minimum voting age being lowered from 20 to 18 years. This, we surmise, is not a substantial change. Likewise, we do not consider minor constitutional amendments or changes to the electoral formulae to be sufficient for constituting regime change. While setting the threshold for what constitutes a substantial change is (inherently) open to discussion, we streamlined a set of criteria and pursue them consistently across contexts. ${ }^{3}$ These criteria are presented

\footnotetext{
${ }^{3}$ All codings come with a set of detailed notes elaborating on our decision, allowing researchers preferring
} 
and discussed in Appendices E-F. To mention one prominent example, we consider a regime change to have occurred if suffrage - in a regime holding contested multi-party elections and where these formal rules for leader selection is followed - is extended from only being granted to males to being universal. Sometimes a number of smaller changes to formal or informal rules, spaced out over a period of time, may incrementally add up to a substantial change. In such cases, it hard to determine exactly when the regime change occurred. Yet, if the accumulated changes are substantial, we still count such processes as regime change. To illustrate this, we discuss the example of Italy in the 1920s and the transition to a Fascist regime led by Mussolini below.

Finally, we highlight that in cases where formal and informal rules diverge (or where no formal rules exist at all), a key feature of the incumbent regime is the coalition of actors that select and sustain leaders; these actors administer the informal rules. When such coalitions change dramatically, so to, we presume, do the informal rules and practices of selecting and maintaining leaders. Thus, in settings where formal rules have little relevance, the make-up of the support coalition can help us in identifying regime units. As common examples of operational criteria, we consider who makes up a military junta and who supports them as relevant for delineating many military regimes, while royal families and their rules for familial inheritance help define monarchical regimes.

\section{The contents of HRD and patterns in regime devel- opment throughout modern history}

HRD includes variables on regime start dates, end dates, and modes of breakdown. The latter has 14 categories and exists in both a single-selection (most important) and multiple-selection format, capturing that multiple processes may lead up to, and be relevant for, breakdown. In addition, dichotomous variables record uncertainty in the date variables and whether a country experiences an interregnum period (which is used very sparsely; see Appendix D). We code regime breakdowns and origins down to the day, where possible, describing even short-lived and transitory regimes in sequence, rather than settling for a coarse account of history. To exemplify, we capture the twelve different coups that took place in Haiti prior to the 1915 U.S. occupation, down to their date.

The 197 polities covered by HRD include the vast majority of sovereign states (e.g., Bavaria, 1789-1871 or Ethiopia, 1789-2016), several semi-autonomous polities (e.g., Hungary

higher thresholds for counting regime change to re-code the units. 
Figure 2: Absolute number of regimes per year included in the dataset, 1789-2016

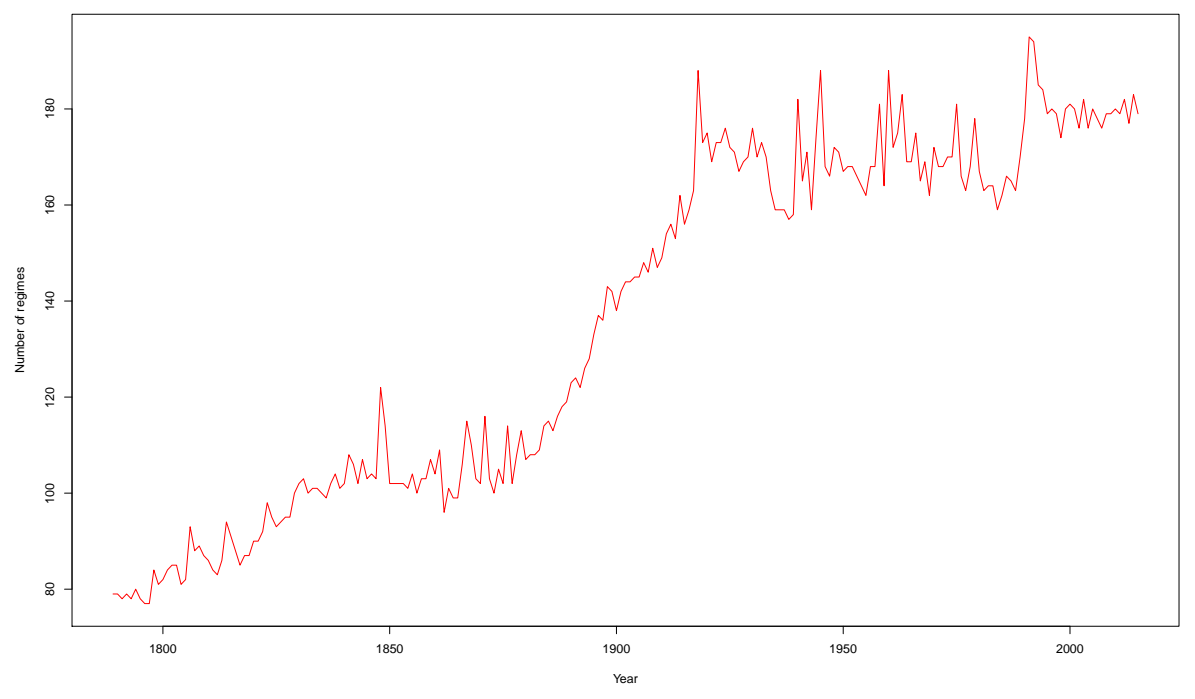

under the Dual Austrian-Hungarian Monarchy), and numerous colonies (e.g., British India). Figure 2 displays the number of regimes that existed during a given year, from 1789-2016, with the increasing trend reflecting that the number of polities included is growing (especially around 1900). Appendix Table A-1 lists all polity-years covered by HRD.

In fact, for the polities included from 1789, the first recorded regime is the one that existed on January 1st that year. Thus, France's first regime (Louis XV's Maupeou parliaments) extends from 1768-1789, but other regimes have birth dates further back in time. Examples are Japan under Tokugawa rule, where the end of the siege of Osaka (January 22, 1615) marks the start date, and Peru under Spanish colonial administration, where the Viceroyalty of Peru is dated back to $1543 .^{5}$

There is substantial geographical variation in the frequency of regime changes in HRD, which stems partly from some countries having longer time series than others and partly

\footnotetext{
${ }^{4}$ These are the polities covered by Historical V-Dem (1789-1920) and by V-Dem v.7 (1900-2016).

${ }^{5}$ Despite the careful assessment of all available sources that our coders could identify (in English, but also in Spanish, Italian, German and other languages where relevant), there is a dearth of sources with fine-grained accounts for some smaller and medium-sized polities, especially in early years. Hence, we may under-count number of regime changes in such instances. This possibility is illustrated by Bolivia, which was among the countries where we employed a second coder for inter-coder reliability tests (see Appendix B). The second coder failed to identify two (of the many) regime changes (via coups) in the 1930s that the original coder had identified, but only from one particular source (namely Hudson and Hanratty, 1991, 28-32). Yet, our inter-coder reliability tests show that the coders, in general, mostly pick up and code the same instances of regime change, implying that the issue of under-counting may not be too large.
} 
Figure 3: Number of recorded regime changes, 1789-2016

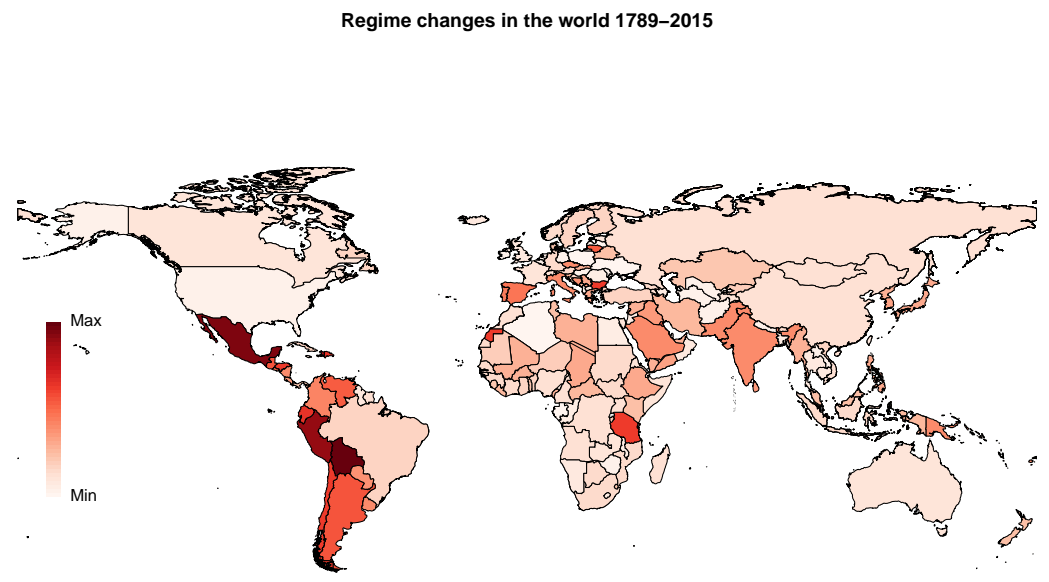

from some countries having more "eventful" political histories. Figure 3 reveals that Central and South America have many recorded regimes. For example, Peru has 41 recorded regimes, Mexico has 43, and Bolivia has 45. But, also West Africa, the Arabian peninsula, South Asia, and Southern Europe display relatively many regimes. Spain, for example, has 22 recorded regime changes, mainly owing to the seven tumultuous decades between the Napoleonic occupation in 1808 and the implementation of constitutional monarchy in 1876 counting 16 regimes. North America, North Europe and East Asia display relatively few regime changes (despite long time series). For instance, Sweden only counts 7 regimes, whereas Canada and Japan have 6 each. As we return to in the final section, there is also considerable variation in regime-change frequency over time. The decades between 1880 and WWI were relatively "stable", with between $1 \%$ and $5 \%$ of extant regimes breaking down in any given year. Also the recent period from 1995 onwards have experienced relative few breakdowns. In contrast, about $20 \%$ of regimes broke down in the revolutionary year of 1848 , a number almost replicated in the years directly following WWI and WWII.

We now turn to discussing the particular variables from HRD and clarifying and exemplifying coding decisions for important and recurring issues. In Appendix B, we further describe the data collection process and routines and division of labor within the team. Appendix C 
includes the notes contained in the dataset for selected countries. ${ }^{6}$

\subsection{Start and end dates}

The regime start and end date variables, v3regstartdate and v3regenddate, respond to the questions: "When did the political regime obtain power?" and "When did the political regime lose power?". For about 140 of 1900 cases it proved extremely difficult to specify exact start dates, and month (about 120 instances) or even year (about 20 instances) was then coded. The cases are assigned dates according to rules laid out in the appendix, and we also code whenever dates are uncertain. Absent interregnum periods, we always code so that the end date of a regime is identical to the start date of the next one. Hence, these dates can be interpreted as denoting date of "regime change".

Figure 4 illustrates the granularity of the data, showing regime changes occurring in European countries in 1848, the "year of revolution" (Rapport, 2008). Several regime changes occured in March following right after the late-February revolution in France. Also some later changes are due to popular uprisings, but yet others are due to guided liberalization of existing regimes as well as "counter revolutions", such as in Prussia in December(coded by HRD as a self-coup). The y-axis displays the duration of the "dying" regime, illustrating that both long-lived regimes, such as the (Post-Pragmatic Sanction) Habsburg regime in Hungary, and very short-lived regimes, such as the "Provisional Government" of Modena that lasted from March 22 to August 8, 1848, broke down. ${ }^{7}$

When the historical sources identified are adequate, military and civilian coup dates are generally clear-cut to register as exact end dates. Also for revolutionary episodes, end dates are often quite easy to pinpoint. Determining start and end dates for other cases are more difficult, including cases where it is clear that a change is occurring whilst the event to mark it is unclear or cases where it is difficult to determine whether the change to formal or informal rules for selecting leaders is substantial enough to constitute breakdown. The former cases include situations when substantial, but gradual, liberalization takes place, and when substantial, but gradual, concentration of power within a narrower ruling elite occurs. Such transition periods are often coded as distinct, shorter-lived regimes. The Italian transition to Fascist rule under Mussolini illustrates this scenario. Clearly, the rules defining Mussolini's reign differed substantially from those of the Kingdom of Italy under the House of Savoy. Yet,

\footnotetext{
${ }^{6}$ The notes and sources for the entire set of countries can be found at ANONYMIZED WEBPAGE.

${ }^{7}$ The Austrian and Hungarian spells from March 1848 to June and October, respectively, are coded as interregnum periods.
} 
Figure 4: Regime end dates in Europe, 1848

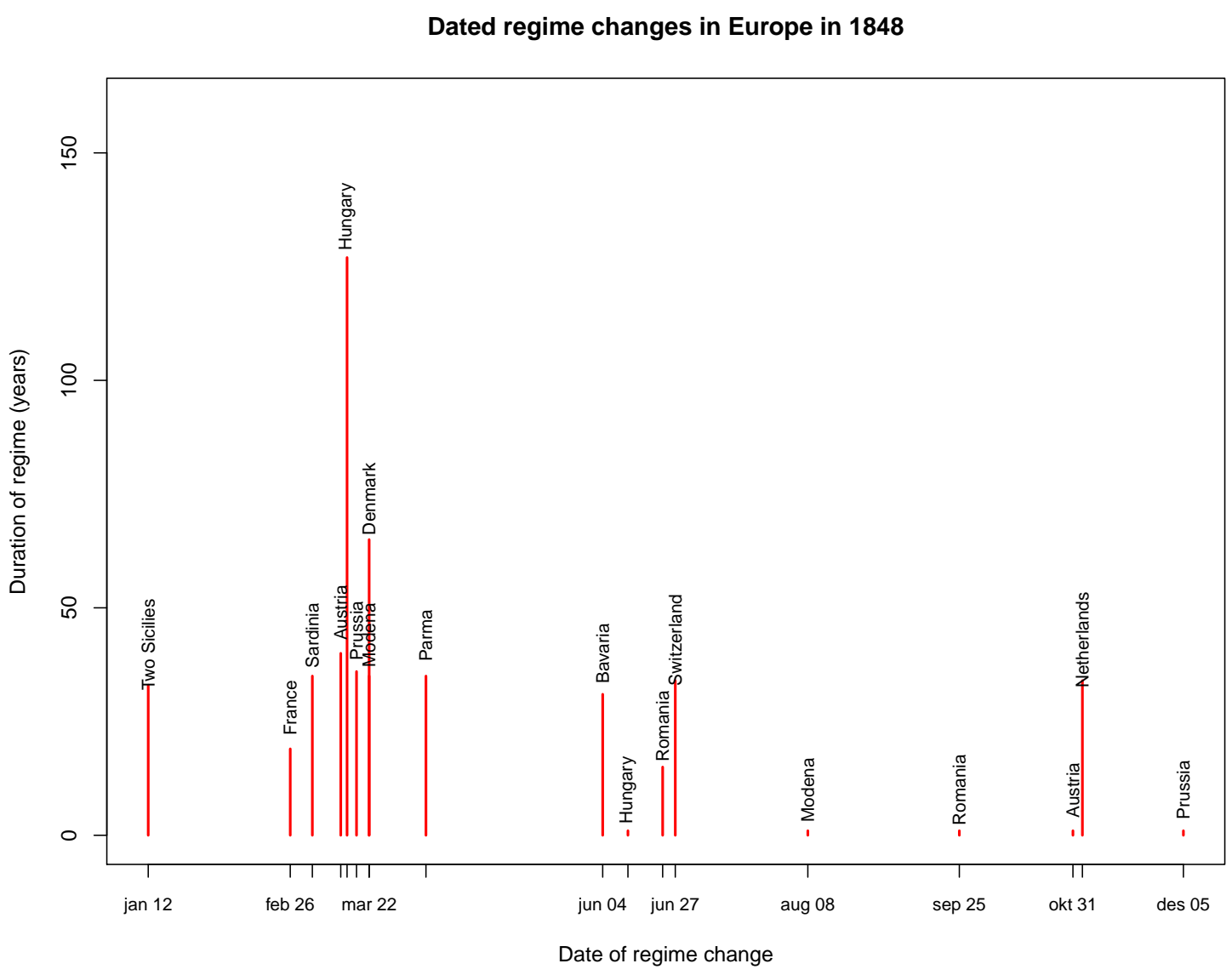


determining the exact transition is challenging. During the 1921-1922 period, the biennio nero ("two black years"), national law enforcement crumbled and paramilitary Fascist groups gained territory and eventually aimed at taking the capital (Smith, 1989). After King Victor Emmanuel III asked Mussolini to form a government on October 29, 1922, this government initially operated under the same constitutional rules as its predecessor. In November 1923, the so-called Acerbo electoral law was passed, stating that the party with the largest share of the vote - even if only a mere 25 percent - would gain an absolute majority of Senate seats. (Yet, it was only in the April 1925 elections that the Acerbo law demonstrated its effect.) This gradual transition is resolved in HRD by coding a separate regime, beginning with Victor Emmanuel's decision on October 29, 1922 and ending with the passing of the Acerbo law, ${ }^{8}$ before coding a new regime representing the definitive Fascist epoch.

\subsection{Regime end type}

The regime end type codings responds to the questions "Could you specify the type of process that you consider the most important in leading to the end of the regime?" (v3regendtype) and "Could you specify the type of processes (one or more) that led to the end of the regime?" (v3regendtypems). HRD thus contains both a single-selection and multiple-selection end type coding. The answers to both questions take the form of categories ( 0 through 13). Figure 5 shows the relative frequency of all modes of regime breakdown, according to v3regendtype, for the entire historical period. "Other guided transformation" - which includes processes such as directed changes from monarchy to republic, the merging of two or more monarchies into one, changes in rules of succession, or colonial transfers to self-rule - is the most frequent mode of breakdown. However, military coups are almost equally frequent, and when combined with "coup by other" (e.g., palace coups in monarchies or coups by certain party members in single-party regimes), coups constitute the most common mode.

Figure 6, drawing on v3regendtype, displays how four particular modes of regime breakdown - coups (by military or others combined), uprisings, interstate war, and guided liberalization - have evolved from 1789-2016. For each mode, we fit a Loess smoothed line (span

\footnotetext{
${ }^{8}$ The decision by Victor Emmanuel was within the boundaries of the law, but was made after three years of near civil war and an armed invasion of Rome. Although we do not know Victor Emmanuel's true motivations - be it fear of civil war or a calculated intention to cooperate with Mussolini - we find it implausible that the decision would have been made without the brutality of the Bienno Nero and the imminent threat of the march on Rome. Thus, we conclude that the informal rules of accessing the premiership were altered sufficiently to constitute regime change.
} 
Figure 5: Relative frequency of all modes of regime change (v3regendtype), across the period 1789-2016

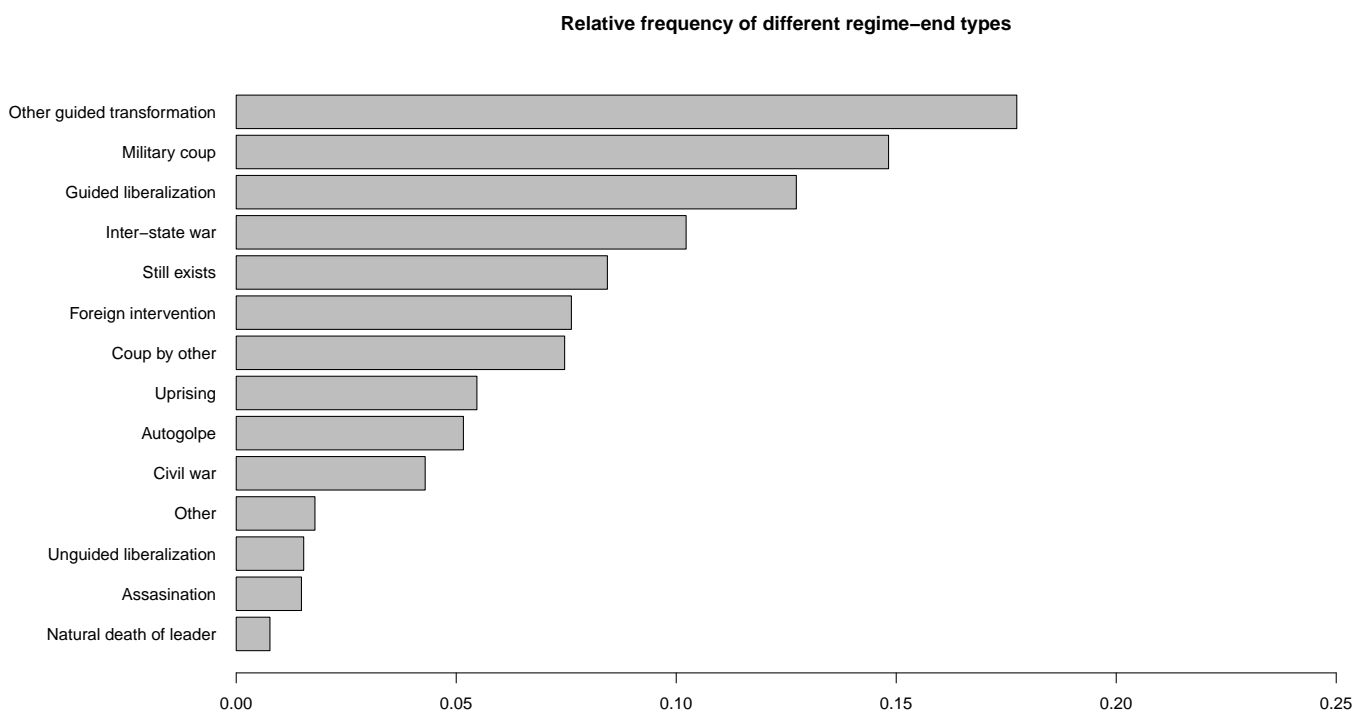

of 0.3) on the annualized relative frequencies, i.e., the share of extant regimes that experienced breakdown associated with a particular mode. Notably, regime deaths associated with these modes have, historically, moved in wave-like fashions. Concerning regime breakdowns due to interstate wars, the early period around the French Revolutionary- and Napoleonic wars and the mid-1900s with the end of WWII, were high-water marks. Smaller wave tops occur around the 1860s and 70s and after WWI. For coups, the 1960s and 70s stand out as a high-frequency period, and regime-ending coups have rapidly declined in more recent decades, as observed by several scholars (e.g., Powell and Thyne, 2011). Yet, a focus on the declining trend in the post-colonial era misses that coups were also relatively frequent in the 1840 s and 50s and in the 1930s, but notably less frequent at the turn of both the 18th and 19th centuries. For uprisings, peaks occur around 1848 and during the 1920s, and uprisings have increased in relative frequency to almost similar levels over the last decade. Hence, our long time series highlight that also this mode of breakdown has moved in a non-monotonic fashion, a nuance that is easy to overlook when focusing on the recent positive trend in regime changes stemming from popular uprisings (e.g., Kendall-Taylor and Frantz, 2014). Likewise, guided liberalization peaked around and after the end of the Cold War, but also the 1820 s and 1860 s were notable high-water marks. 
Figure 6: Yearly frequencies of regime deaths (Loess smoother, span of 0.3) due to coups, uprisings, international war, and guided liberalization, 1789-2016.

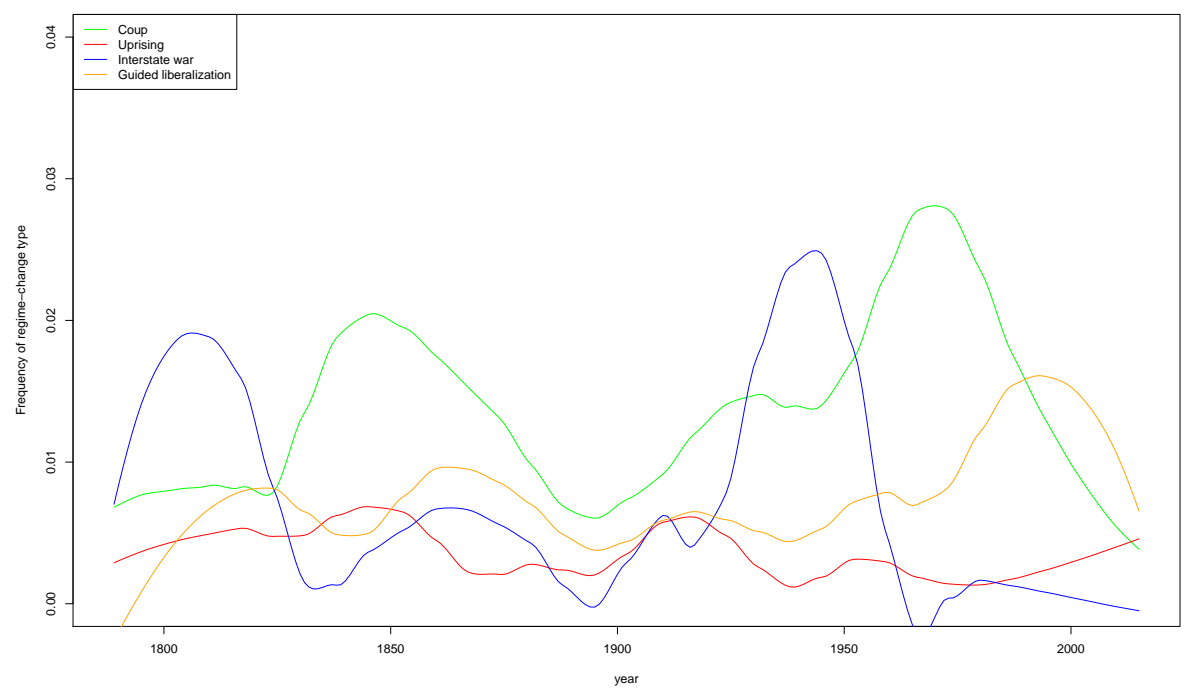

The multiple selection variable, v3regendtypems, is often identical to v3regendtype, indicating that one type of process was the dominant force behind the regime's breakdown. In other cases, singling out only one relevant process is difficult, for example when a regime breaks down after being faced by a large popular revolt that is subsequently followed by a military coup. If so, we make a decision, informed by the sources, on which of the two were relatively more influential behind removing the regime for v3regendtype, but code both as relevant for v3regendtypems.

Finally, we note that the nature of the processes leading to regime breakdown sometimes are susceptible to controversy among historians and other experts. ${ }^{9}$ Take, for example, the regime death prior to the inclusion of Montenegro in the Kingdom of Serbs, Croats and Slovenes in 1918. Montenegro had been occupied by Allied and Serbian forces in the final stages of WWI. On 24-26 November, the Podgorica Assembly voted to unite Montenegro with the Kingdom under Prince-regent Aleksandar of the Karadjordjevic dynasty. Yet, the Podgorica Assembly has been widely criticized for not including representatives from a sufficiently broad segment of Montenegrins (Andrijašević and Rastoder, 2006; Roberts, 2007). Thus, deciding whether this is a directed and willed transition (category 10) or a result of foreign intervention by Serbia (category 7) is unavoidably controversial. For v3regendtype,

\footnotetext{
${ }^{9}$ One recurring and difficult distinction is between directed transitions and self-coups; see Appendix G.
} 
we code this as a directed transition. But, the controversy is recognized in the accompanying notes and in the coding of v3regendtypems.

\section{Extant studies on determinants of regime breakdown}

The vast literature on why regimes break down suggests determinants related to internationalsystemic, geographical, demographic, cultural, economic, and political-institutional factors. We focus on three key determinants, two economic and one political-institutional, which are also the focus of our empirical analysis. We start by discussing two widely assumed structural conditions for regime breakdown, namely income level and level of democracy, before we turn to a prominent "trigger", economic crisis.

One important strand of research has considered how "economic development" conditions regime change, notably including classic studies of democratization. Lipset (1959), for instance, proposed that the societal changes following economic development would, over time, undermine the legitimacy of autocratic regimes and make them struggle to govern effectively, ultimately spurring transition towards democracy. Yet, several recent studies fail to find a clear link between development, operationalized as GDP per capita, and democratizing regime changes (e.g., Przeworski and Limongi, 1997; Acemoglu, 2008). Subsequent studies have, however, questioned these recent null-results, for instance highlighting that results from the post-WWII era are not generalizable to earlier time periods (Boix, 2011). Further, when disaggregating the process of democratization, Kennedy (2010) finds that the aggregate null-relationship stems from a high income level stabilizing all types of regimes both autocratic and democratic - but that when an autocratic regime first breaks down, it is much more likely to be replaced by a democracy in rich countries. There are different reasons for why high income may stabilize not only democracies, but also autocratic regimes, including reduced poverty-related grievances and an improved availability of financial resources that the regime can leverage for repression or co-optation. The expectation that income stabilizes all types of regimes is, to some extent, backed up by extant findings on revolutions (Knutsen, 2014), one common mode of regime breakdown, and the relationship between low income levels and civil war onset is even more robust (Hegre and Sambanis, 2006). Yet, studies assessing the link between income and coups d'état in recent decades (Powell, 2012; Gassebner, Gutmann and Voigt, 2016) do not find a clear association.

Other accounts of regime breakdown have focused on political institutions. ${ }^{10}$ Notably,

\footnotetext{
${ }^{10}$ Institutional features proposed to stabilize autocratic regimes include electoral institutions (e.g., Gandhi
} 
different studies find that regimes "in the middle" of the autocracy-democracy spectrum, i.e. regimes displaying some combination of democratic and autocratic features, are more likely to break down than relatively autocratic- and relatively democratic regimes (e.g., Gates et al., 2006; Goldstone et al., 2010; Knutsen and Nygård, 2015). One proposed reason for why mixed regimes are less stable, is that they, unlike autocracies, are unable to sufficiently repress and deter regime opposition, while they are also, unlike democracies, unable to accommodate opposition groups through institutionalized channels of influence and competition over positions of power. A related literature (e.g., Hegre et al., 2001) has found that mixed regimes more often experience civil war (but, see Vreeland, 2008), whereas Bodea, Elbadawi and Houle (2017) find that (certain types of) mixed regimes experience more riots and coups d'état.

Regarding triggers of regime breakdown, the "revolutionary-threat" thesis, formalized by Acemoglu and Robinson (2006), emphasize sudden shocks in the capacity of the opposition to mobilize and threaten the regime from the outside. Revolutionary threats seem to have prompted democratization in several European countries in the 19th and early 20th centuries (Aidt and Jensen, 2014), either directly through revolution or indirectly through "forcing" the regime to liberalize in a guided manner. One key shock that may trigger revolts is economic crisis (e.g., Davies, 1962; Gurr, 1970; Acemoglu and Robinson, 2006). While economic crises come in different forms, a sharp drop in economic growth is a typical characteristic. Crises may induce grievances among opposition groups and key regime supporters through loss of income (and employment), but also through reduced public revenue leading to less transfers through social policies (Ponticelli and Voth, 2011) or patronage (Bratton and van de Walle, 1997). Due to their relatively sudden and public nature, economic crises may also function as "coordination signals" (see Kuran, 1989) for opposition actors, enabling collective action directed towards the regime. Hence, different studies show that crises, often proxied by slow/negative economic growth, are strongly correlated with regime breakdown or more specific processes associated with breakdown. Przeworski and Limongi (1997) find that economic crises spur both democratization and democratic breakdown (see also Kennedy, 2010; Ciccone, 2011; Aidt and Leon, 2015). Low short-term growth also predicts civil wars (Hegre and Sambanis, 2006), riots and protests (Ponticelli and Voth, 2011), revolutions (Knutsen,

and Lust-Okar, 2009; Knutsen, Nygård and Wig, 2017), legislatures (e.g., Gandhi, 2008; Boix and Svolik, 2013), and strong regime parties (e.g., Geddes, 1999; Magaloni, 2008). Studies on democratic breakdown suggest that a parliamentary (rather than presidential) system (e.g., Linz, 1990) or simply having a strong parliament capable of monitoring and reviewing executive actions (e.g., Fish, 2006) reduce chances of breakdown, reflecting that self-coups by chief executives is a common process behind why democracies die (e.g., Svolik, 2008). 
2014), and coups (Gassebner, Gutmann and Voigt, 2016).

\section{Correlates of regime duration and breakdown}

To assess the relevance of the three discussed determinants we employ a parsimonious model of regime breakdown. Income is measured by (logged, PPP-adjusted) GDP per capita from (Fariss et al., 2017). Annual GDP per capita growth is also constructed from these data. (Fariss et al., 2017) provide estimates of income (and population) by drawing on information from different historic and contemporary sources and using a dynamic latent trait model. We use their estimates benchmarked in the long-time series data from the Maddison project. One benefit of using these data is the reduction of various types of measurement errors, but also the estimation of missing values and extended time series. We further include the Polyarchy index (Teorell et al., 2016) of (electoral) democracy from V-Dem (Coppedge et al 2017a), and its squared term, to investigate the anticipated inverted u-curve relationship between level of democracy and regime breakdown. Since Polyarchy is also extended back in time by Historical V-Dem, the time frame of our analysis ranges from 1789 to recent years.

The baseline estimator is a logit model that incorporates duration dependence, capturing time since last regime change in addition to its squared and cubed terms, following Carter and Signorino (2010) - regimes are typically more fragile in their early stages, and regime fragility is a non-linear function of regime duration (Svolik, 2012). We also includes fixed effects on either regions or countries to pick up stable, unit-specific characteristics (e.g., geographic or climatic features) that affect breakdown and correlate with the three determinants. We further include year-dummies to model common global shocks. As discussed, various modes of regime breakdown have evolved in wave-like patterns over time, implying that a linear trend would be unsuitable. Finally, we control for log population from (from Fariss et al., 2017).

Table 2 displays variations of our baseline model with regime breakdown, measured one year after the covariates, as the outcome. The purpose of the first two models is to assess

how sensitive results are to measurement choices. Model 1.1 employs GWF data for the dependent variable and Model 1.2 employs HRD data. As discussed, the conceptualization of what constitutes a regime is quite similar across the two datasets, although there are differences in operational rules, notably with HRD employing a lower threshold for conting regime change. To make results comparable, we estimate these models on the same sample, covering 7246 country-years from 1946-2013. 
Table 2: Logit models with regime breakdown (in $t+1$ ) as dependent variable

\begin{tabular}{lcccc}
\hline & $(1.1)$ & $(1.2)$ & $(1.3)$ & $(1.4)$ \\
& GWF $(1946-2013)$ & HRD $(1946-2013)$ & HRD $(1789-2014)$ & HRD $(1789-2014)$ \\
\hline Democracy & $14.793^{* * *}$ & $9.130^{* * *}$ & $5.007^{* * *}$ & $6.685^{* * *}$ \\
& $(7.00)$ & $(6.09)$ & $(7.32)$ & $(7.05)$ \\
Democracy & $-21.591^{* * *}$ & $-13.237^{* * *}$ & $-8.198^{* * *}$ & $-10.298^{* * *}$ \\
& $(-7.23)$ & $(-7.02)$ & $(-9.66)$ & $(-9.48)$ \\
L(GDP p.c.) & $-0.325^{*}$ & $-0.257^{* *}$ & $-0.178^{* *}$ & -0.162 \\
& $(-2.54)$ & $(-2.87)$ & $(-3.00)$ & $(-1.70)$ \\
L(population) & -0.067 & -0.014 & -0.034 & $-0.250^{*}$ \\
& $(-0.98)$ & $(-0.33)$ & $(-1.27)$ & $(-2.14)$ \\
GDP p.c. growth & $-0.046^{*}$ & $-0.042^{*}$ & $-0.015^{* *}$ & $-0.012^{*}$ \\
& $(-2.20)$ & $(-2.14)$ & $(-2.92)$ & $(-2.18)$ \\
\hline Duration terms & $\checkmark$ & $\checkmark$ & $\checkmark$ & $\checkmark$ \\
Region-FE & $\checkmark$ & $\checkmark$ & $\checkmark$ & $\checkmark$ \\
Country-FE & & & $\checkmark$ & $\checkmark$ \\
Year-FE & $\checkmark$ & $\checkmark$ & 16435 & -3499.973 \\
\hline $\mathrm{N}$ & 7246 & -1370.092 & -3630.412 & \\
ll & -1047.489 & & & \\
\hline \hline
\end{tabular}

Notes: ${ }^{*} \mathrm{p}<0.05 ;{ }^{* *} \mathrm{p}<0.01 ;{ }^{* * *} \mathrm{p}<0.001$, standard errors are clustered at the country-level. Z-values in parentheses. All independent variables are lagged by 1 year. Constant, fixed effects, and regime-specific time trends (duration, duration ${ }^{2}$, duration $^{3}$ ) omitted from table.

Several clear patterns emerge from Model 1.1 using GWF: High income levels and high short-term growth are both negatively related to probability of regime breakdown. Further, regimes "in the middle" of the autocracy-democracy spectrum are more likely to experience breakdown, as indicated by the positive linear term and negative squared term. The results are very similar in Model 1.2 using HRD. While the coefficient for GDP per capita is moderately reduced, the t-value actually changes from -2.5 to -2.9 , further solidifying the conclusion that regimes are less likely to die in richer countries. The result for short-term growth stays basically unchanged, whereas the linear and squared Polyarchy terms are reduced in size - suggesting a somewhat less sharp inverse "U-curve" between democracy level and probability of regime breakdown. Thus, the main conclusion drawn from comparing 1.1 and 1.2 is that the choice of GWF vs HRD regime coding does not strongly influence the substantive interpretations on how income, growth, and democracy level influence regime breakdown. (This does, of course, not imply that results will be similar for other covariates than those we have tested.)

Still, the main advantage of the HRD data relative to GWF is the vastly expanded time series, extending back to 1789 instead of 1946. Leveraging these longer time series improves our ability to assess how robust, for instance, level of democracy and income level are as general determinants of regime breakdown. There are strong a priori reasons to believe that 
these relationships have varied substantially across time, including developments in potential moderating factors related, e.g., to the structure of the international political system and communications- and military technology over the course of modern history. Model 1.3 represents the same specification as Model 1.2, but extends the time frame to 1789-2014 (16,435 country-year observations). Surprisingly, the results turn out very similar when employing the extended time series. Low income levels, slow growth, and intermediate levels of democracy are clearly associated with enhanced risk of regime breakdown. While there certainly are changes to the point estimates, the key take-away from comparing Models 1.2 and 1.3 is that standard errors are (often substantially) reduced. For instance, the growth coefficient is now more precisely estimated, with a t-value of -2.9 instead of -2.1 , despite the point estimate being reduced from -0.042 to -0.015 .

While accounting for country-specific effects is often crucial for mitigating omitted variable bias, it is also often regarded as infeasible in analysis of regime change, and other infrequently occurring phenomena such as wars, when time series are limited (Beck and Katz, 2001). Luckily, the long time series and multiple, recorded regime changes for most countries in Model 1.3 opens up to accounting for country-specific historical factors without being too worried about loss of efficiency. Thus, Model 1.4 substitutes region-fixed effects with country-fixed effects. Polyarchy and growth remain stable, while the coefficient for income level decreases somewhat and loses statistical precision $(t=1.70)$. Hence, some of the differences in breakdown risk between rich and poor countries relates to between-country variation, and we should therefore not conclude too forcefully on whether income affects breakdown.

\subsection{Extensions: Investigating heterogeneity across modes of break- down and across time}

So far, we have highlighted how HRD's extensive coverage allows us to more carefully assess the robustness of proposed determinants of regime change, for instance by controlling for country-fixed effects. However, the specific measures and extensive time series in HRD also open up for assessing different forms of heterogeneity. We start out by assessing whether the predictors discussed above are differently linked to different modes of regime breakdown; the models in Table 3 leverage the v3regendtype coding, distinguishing between four modes These are coups (military coups and coups by others, combined), inter-state war, popular uprising, and "guided transformation" (combining the two categories for guided liberalization and other guided transformation). 
Table 3: Logit models with different modes of regime breakdown (in $t+1)$ as dependent variable

\begin{tabular}{lcccc}
\hline & $(2.1)$ & $(2.2)$ & $(2.3)$ & $(2.4)$ \\
\hline Outcome: & Coup & Uprising & War & Reform \\
\hline Democracy & $7.308^{* * *}$ & 3.843 & $-4.749^{*}$ & $13.402^{* * *}$ \\
& $(5.00)$ & $(1.19)$ & $(-2.03)$ & $(7.03)$ \\
Democracy $^{2}$ & $-10.566^{* * *}$ & $-12.276^{*}$ & 3.459 & $-17.950^{* * *}$ \\
& $(-5.36)$ & $(-2.29)$ & $(1.30)$ & $(-7.64)$ \\
L(GDP p.c.) & -0.212 & $-0.658^{* * *}$ & 0.155 & -0.013 \\
& $(-1.49)$ & $(-3.30)$ & $(0.58)$ & $(-0.11)$ \\
L(population) & 0.003 & $0.245^{*}$ & -0.107 & 0.035 \\
& $(0.05)$ & $(2.41)$ & $(-0.97)$ & $(0.51)$ \\
GDP p.c. growth & $-0.009^{* *}$ & $-0.015^{*}$ & -0.014 & 0.010 \\
& $(-2.82)$ & $(-2.07)$ & $(-1.92)$ & $(1.91)$ \\
\hline Region-FE & $\checkmark$ & $\checkmark$ & $\checkmark$ & $\checkmark$ \\
Year-FE & $\checkmark$ & $\checkmark$ & $\checkmark$ & $\checkmark$ \\
Duration terms & $\checkmark$ & $\checkmark$ & $\checkmark$ & $\checkmark$ \\
N & 12404 & 3929 & 2292 & 9582 \\
ll & -1224.189 & -259.232 & -301.091 & -715.131 \\
\hline
\end{tabular}

Notes: ${ }^{*} \mathrm{p}<0.05 ;{ }^{* *} \mathrm{p}<0.01 ;{ }^{* * *} \mathrm{p}<0.001$, standard errors are clustered at the country-level. Z-scores in parentheses. All independent variables are lagged by 1 year. Constant, fixed effects, and regime-specific time trends (duration, duration ${ }^{2}$, duration ${ }^{3}$ ) omitted from table.

Model 2.1, Table 3 replicates Model 1.3, Table 2, but estimates the risk of experiencing a regime change through coups. Overall, these models report quite similar results. Regimes with intermediate levels of democracy are more prone to break down because of coups, and there is a negative and significant coefficient for short-term growth. Income level also has a similarly signed point estimate as in Model 1.3, but the t-value is only -1.5. Model 2.2 estimates the risk of breakdown due to popular uprisings, also showing similarly signed coefficients as for the (overall) regime breakdown model. Yet, the inverse-u shape relationship with democracy is less clear than for breakdowns overall or for coup-breakdowns. In contrast, low income level has a much stronger relationship to uprisings than coups, and economic crises are also clearly linked to breakdowns emanating from popular uprisings. Model 2.3 considers regime breakdowns due to inter-state war. Here, we find very little similarity with Model 1.3 on all breakdowns. Neither income levels nor intermediate levels of democracy are strong predictors of war-induced transitions, and short-term growth is only a weakly significant predictor $(t=-1.92)$. Finally, Model 2.4 investigates guided regime transitions. Here, only democracy level is a clear predictor, with regimes "in the middle" being more likely to engage in guided regime transitions.

In sum, we identify a fair amount of heterogeneity concerning which predictors explain different modes of breakdown. While an intermediate level of democracy is related to break- 
downs via coups or guided regime transitions, it does not systematically relate to a higher probability of war-induced transitions. Economic crises - as proxied by GDP per capita growth - increase the chances of transitions via coups and uprisings, but not guided regime transitions. In contrast, low levels of income are only clearly relevant for breakdowns spurred by popular uprisings.

Next, we investigate heterogeneity across time, returning to the dependent variable capturing all forms of regime transitions (similar investigations of temporal heterogeneity for coup- and uprising transitions, counted separately, are briefly presented in Appendix I). Whereas the literature has focused on the question of whether democratization episodes occur in "waves" (e.g., Huntington, 1991), one understudied question is whether there are marked "waves" also in the stability/breakdown of regimes, more generally. Are there certain periods of modern history with a sustained and statistically marked uptick in the frequency of regime breakdowns, followed by "crests" where breakdowns are less frequent?

To systematically study such structural breaks in the frequency of regime change, we estimate a Bayesian change point model on average number of regime breakdowns (across all polities, in a given year), using Markov Chain Monte Carlo. ${ }^{11}$

Using this procedure, we identify four structural breaks in the global frequency of regime breakdowns. We observe two "waves", the first from 1798-1881 and the second from 19131995, both followed by two crest periods where the global frequency of breakdowns drops substantially. Figure 7 shows the posterior probability of each structural period (top), and the global mean of breakdown frequency (with structural break-years inserted; bottom). The identified change points are not without intuitive sense: Starting in 1798 (during the French Revolutionary Wars), the world observed a range of regime transitions, for instance with several occurring in German and Italian states invaded by (or allied with) France during the ensuing Napoleonic wars. While the number of transitions tailed off after the Congress of Vienna in 1815, the dip is insufficient for our model to identify a significant change point. The number of transitions then increased again, notably with the European revolutions and

\footnotetext{
${ }^{11}$ Following the specification used by Knutsen and Nygård (2015), we run a linear Gaussian model, with multiple change points defined by the user, where the posterior likelihood we sample from is:

$$
y_{t}=x_{t} \beta_{t}+I\left(s_{t}=i\right) \epsilon_{t}, i=1, \ldots, k
$$

where $k$ is the number of "states" (or change points +1 ), $I\left(s_{t}=i\right)$ is an indicator function that equals 1 in state $t$ and 0 otherwise, $x$ is the set of covariates (we do not employ any in this analysis), and $\epsilon$ is a stochastic error. We set the prior mean of $\beta$ to the empirical mean over the entire sample, and the prior standard deviation of $\beta$ to the empirical standard deviation. We conduct tests looking for 2, 3, 4 or 5 structural breaks, and find that 4 change points yields the best fit to the data.
} 
Figure 7: Results from Change Point model
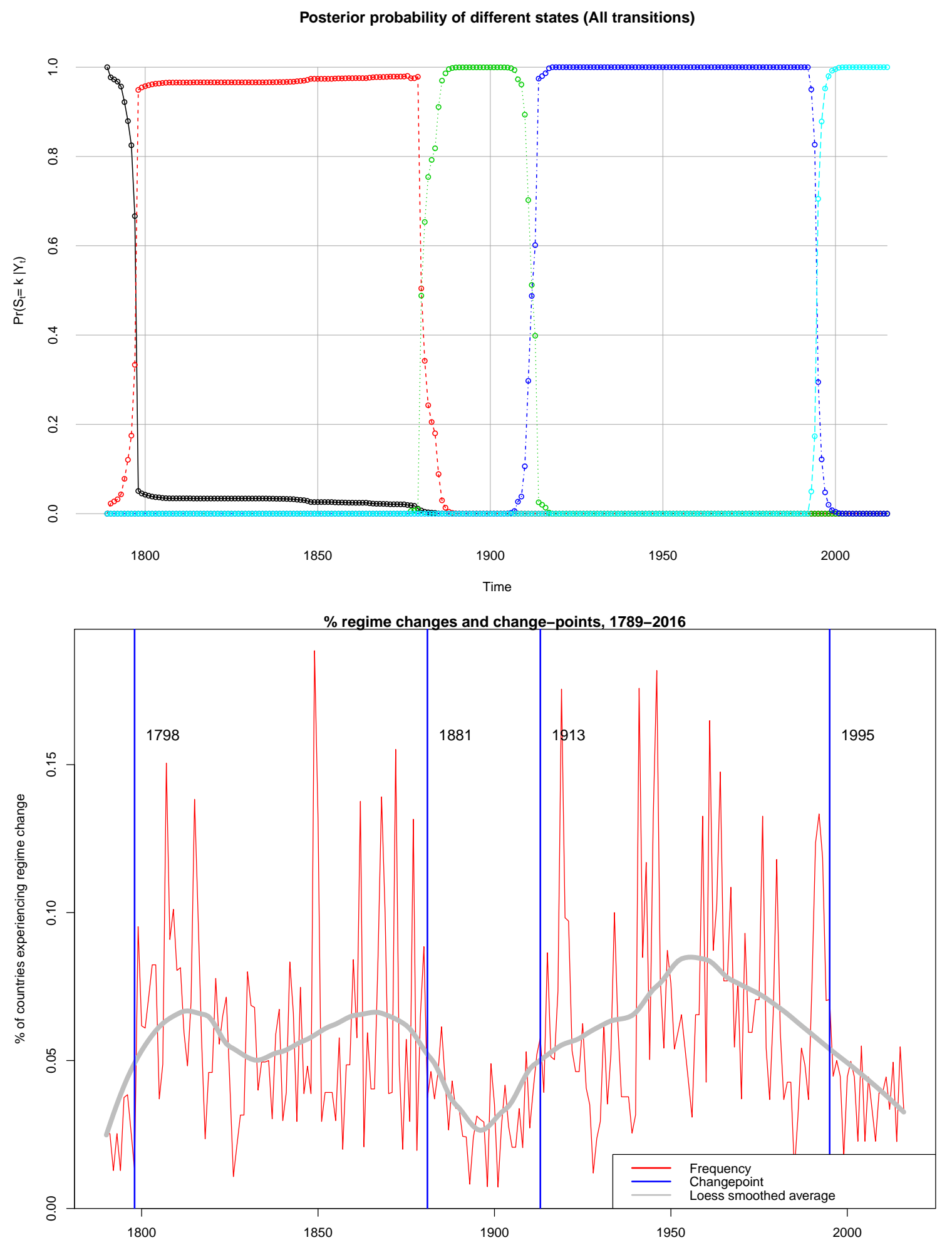
Table 4: Logit models of regime breakdown (in $\mathrm{t}+1$ ) in Wave and Crest periods

\begin{tabular}{lcccccc}
\hline & $(3.1)$ & $(3.2)$ & $(3.3)$ & $(3.4)$ & $(3.5)$ & $(3.6)$ \\
\hline Period: & $1798-1881$ & $1881-1913$ & $1913-1995$ & $1995-2014$ & Wave periods & Crest periods \\
Wave/Crest & Wave I & Crest I & Wave II & Crest II & Waves I-II & Crests I-II \\
\hline Democracy & 1.249 & 1.938 & $6.940^{* * *}$ & $5.323^{*}$ & $4.926^{* * *}$ & $5.876^{* * *}$ \\
& $(0.56)$ & $(0.78)$ & $(7.25)$ & $(1.96)$ & $(6.13)$ & $(4.32)$ \\
Democracy ${ }^{2}$ & -9.559 & -6.232 & $-10.298^{* * *}$ & $-7.242^{*}$ & $-8.179^{* * *}$ & $-8.818^{* * *}$ \\
& $(-1.86)$ & $(-1.56)$ & $(-8.21)$ & $(-2.24)$ & $(-7.85)$ & $(-5.51)$ \\
L(GDP p.c.) & -0.023 & $-0.390^{*}$ & $-0.283^{* * *}$ & $-0.389^{*}$ & $-0.132^{*}$ & $-0.354^{* *}$ \\
& $(-0.19)$ & $(-2.15)$ & $(-3.75)$ & $(-2.44)$ & $(-2.06)$ & $(-2.78)$ \\
L(population) & -0.040 & $-0.207^{*}$ & -0.018 & 0.038 & -0.040 & -0.032 \\
& $(-0.52)$ & $(-2.22)$ & $(-0.56)$ & $(0.51)$ & $(-1.35)$ & $(-0.51)$ \\
GDP p.c. growth & -0.002 & -0.008 & $-0.014^{*}$ & -0.020 & $-0.015^{* *}$ & -0.021 \\
& $(-0.04)$ & $(-0.43)$ & $(-2.50)$ & $(-1.34)$ & $(-2.72)$ & $(-1.58)$ \\
\hline Region-FE & $\checkmark$ & $\checkmark$ & $\checkmark$ & $\checkmark$ & $\checkmark$ & $\checkmark$ \\
Year-FE & $\checkmark$ & $\checkmark$ & $\checkmark$ & $\checkmark$ & $\checkmark$ & $\checkmark$ \\
Duration terms & $\checkmark$ & $\checkmark$ & $\checkmark$ & $\checkmark$ & $\checkmark$ & $\checkmark$ \\
\hline N & 2505 & 1573 & 8797 & 2366 & 11362 & 4758 \\
AIC & 1368.264 & 754.503 & 4416.606 & 777.265 & 5861.096 & 1691.623 \\
\hline \hline
\end{tabular}

Notes: ${ }^{*} \mathrm{p}<0.05 ;{ }^{* *} \mathrm{p}<0.01 ;{ }^{* * *} \mathrm{p}<0.001$, standard errors are clustered at the country-level. Z-scores in parentheses. All independent variables are lagged by 1 year. Constant, fixed effects, and regime-specific time trends (duration, duration ${ }^{2}$, duration ${ }^{3}$ ) omitted from table.

counter-revolutions of 1848/9, but also numerous coups in Latin American countries in the following decades. Only after the First Boer War in 1881 (with the Congress of Berlin coming three years later) - during a period of peace in Europe where major powers carved up the world into colonies - there is a lull in the number of breakdowns. This lull lasts until right before the peace in Europe is broken (1913) with WWI. From 1913-1995, there is again a long, high-intensity period of regime breakdowns that encapsulates the inter-war period, WWII, the de-colonization of Africa and Asia, and the Cold War - all global events associated with numerous regime changes. After the end of the Cold War, and the ensuing breakdown of (Communist and other) long-standing autocracies especially in Eastern Europe and Sub-Saharan Africa, our model suggests that we entered a new crest period around 1995.

How well does our baseline model explain variation in regime change in these different wave- and crest-periods? Table 4 shows our baseline model estimated on samples split by the different wave and crest periods identified in figure 7. While the coefficient sizes and significance levels vary somewhat across the periods, the signs of the coefficients are consistent for democracy level, income level, and short-term growth. The results are, however, more precisely estimated for the second wave 1913-1995 (which also contains the highest number of observations), whereas none of the predictors are significant at $5 \%$ for the first wave from 1798-1881. When merging the wave (Model 3.5) and crest (3.6) periods together, we find 
that intermediate levels of democracy and low income level are positively related to regime breakdown in both types periods, although the income coefficient is much more sizeable during crests. For short-term growth, the coefficient size is fairly similar across wave and crest periods, but only statistically significant at conventional levels during waves.

\section{Conclusion}

We chart the breakdown of political regimes globally across more than two centuries by using our new and comprehensive HRD dataset. These data include information on more than 1900 regimes from 197 polities, recording, for example, the precise duration and mode of breakdown of these regimes. These data will help future efforts to study the life and death of regimes, and various forms of regime transitions, in a systematic manner.

Drawing on this dataset we have described various patterns of regime duration and breakdown throughout modern history and investigated three proposed determinants of regime change. We find fairly robust evidence that regimes in poor countries, countries that experience slow short-term growth, and regimes that display intermediate levels of democracy are more likely to suffer regime breakdown. All of these relationships are particularly clear when focusing on the period from the beginning of WWI to after the end of the Cold War, a period of modern history characterized by frequent regime changes. When investigating distinct modes of regime breakdown, however, we find indications of heterogeneity - some predictors are more relevant for certain modes of breakdown than others. For instance, intermediate levels of democracy are associated with more regime breakdowns due to coups and guided regime transformations, whereas low short-term growth is associated with regime deaths due to coups and popular uprisings. While we note that further theory development and additional testing is required before we can say anything definite about heterogeneity in relationships, be it across time or modes of breakdown, our study has illustrated how the new HRD data enables such nuanced studies. 


\section{References}

Abrahamian, Ervand. 2013. The coup: 1953, the CIA, and the roots of modern US-Iranian relations. New York, NY: The New Press.

Acemoglu, D. 2008. Introduction to Modern Economic Growth. Princeton: Princeton University Press.

Acemoglu, Daron and James A. Robinson. 2006. Economic Origins of Dictatorship and Democracy. New York, NY: Cambridge University Press.

Aidt, Toke S and Gabriel Leon. 2015. "The Democratic Window of Opportunity Evidence from Riots in Sub-Saharan Africa." Journal of Conflict Resolution p. 0022002714564014.

Aidt, Toke S. and Peter S. Jensen. 2014. "Workers of the world, unite! Franchise extensions and the threat of revolution in Europe, 18201938." European Economic Review 72(0):52 75 .

Andrijašević, Živko M and Šerbo Rastoder. 2006. The History of Montenegro, from Ancient Times to 2003. Podgorica: Montenegro Disapora Centre.

Beck, Nathaniel and Jonathan N. Katz. 2001. "Throwing out the Baby with the Bath Water: A Comment on Green, Kim, and Yoon." International Organization 55:187-195.

Bodea, Christian, Ibrahim Elbadawi and Christian Houle. 2017. "Do Civil Wars, Coups and Riots Have the Same Structural Determinants?" International Interactions 43:537-561.

Boix, Carles. 2011. "Democracy, Development, and the International System." American Political Science Review 105(4):809-828.

Boix, Carles, Michael Miller and Sebastian Rosato. 2013. "A Complete Data Set of Political Regimes, 1800-2007." Comparative Political Studies 46(12):1523-1554.

Boix, Carles and Milan W. Svolik. 2013. "The Foundations of Limited Authoritarian Government: Institutions, Commitment, and Power-Sharing in Dictatorships." Journal of Politics 75(2):300-316.

Bratton, Michael and Nicholas van de Walle. 1997. Democratic Experiments in Africa: Regime Transitions in Comparative Perspective. Cambridge: Cambridge University Press.

Bueno de Mesquita, Bruce, Randolph M. Siverson and Gary Woller. 1992. "War and the Fate of Regimes: A Comparative Analysis." American Political Science Review 86(3):638-646.

Carter, David B. and Curtis S. Signorino. 2010. "Back to the Future: Modeling Time Dependence in Binary Data." Political Analysis 18(3):271-292.

Cheibub, Jose, Jennifer Gandhi and James Vreeland. 2010. "Democracy and dictatorship revisited." Public Choice 143(1-2):67-101. 
Chenoweth, Erica and Maria J. Stephan. 2011. Why Civil Resistance Works: The Strategic Logic of Nonviolent Conflict. Columbia University Press.

Ciccone, Antonio. 2011. "Economic Shocks and Civil Conflict: A comment." American Economic Journal: Applied Economics (3):215-227.

Coppedge, Michael. 2012. Democratization and Research Methods. Cambridge University Press.

Coppedge, Michael, John Gerring, Staffan Lindberg, Svend-Erik Skaaning, Jan Teorell, David Altman, Michael Bernhard, Steven Fish, Adam Glynn, Allen Hicken, Carl Henrik Knutsen, Joshua Krusell, Anna Lührmann, Kyle L. Marquardt, Kelly McMann, Valeriya Mechkova, Moa Olin, Pamela Paxton, Daniel Pemstein, Josefine Pernes, Constanza Sanhueza Petrarca, Johannes von Rmer, Laura Saxer, Brigitte Seim, Rachel Sigman, Jeffrey Staton, Natalia Stepanova and Steven Wilson. 2017a. "Varieties of Democracy (V-Dem) Dataset v7." Varieties of Democracy (V-Dem) Project.

Davies, James C. 1962. "Towards a Theory of Revolution." American Sociological Review $27(1): 5-19$.

Fariss, Christopher J., Charles D. Crabtree, Therese Anders, Zachary M. Jones, Fridolin J. Linder and Jonathan N. Markowitz. 2017. "Latent Estimation of GDP, GDP per capita, and Population from Historic and Contemporary Sources." Working paper.

Fish, Steve. 2006. "Stronger legislatures, stronger democracies." Journal of Democracy 17:520.

Gandhi, Jennifer. 2008. Political Institutions under Dictatorship. Cambridge: Cambridge University Press.

Gandhi, Jennifer and Ellen Lust-Okar. 2009. "Elections under Authoritarianism." Annual Review of Political Science 12:403-422.

Gasiorowski, Mark J. 1987. "The 1953 coup d'etat in Iran." International Journal of Middle East Studies 19(3):261-286.

Gasiorowski, Mark J and Malcolm Byrne. 2004. Mohammad Mosaddeq and the 1953 coup in Iran. Syracuse, NY: Syracuse University Press.

Gassebner, Martin, Jerg Gutmann and Stefan Voigt. 2016. "When to expect a coup détat? An extreme bounds analysis of coup determinants." Public Choice 169:293-313.

Gates, Scott, Håvard Hegre, Mark P. Jones and Håvard Strand. 2006. "Institutional Inconsistency and Political Instability: Polity Duration, 1800-2000." American Journal of Political Science 50(4):893-908. 
Geddes, Barbara. 1999. "What Do We Know About Democratization After Twenty Years?" Annual Review of Political Science 2:115-144.

Geddes, Barbara, Joseph Wright and Erica Frantz. 2014. "Autocratic Breakdown and Regime Transitions: A New Data Set." Perspectives on Politics 12(2):313-331.

Goldstone, Jack A., Robert H. Bates, David L. Epstein, Ted Robert Gurr, Michael B. Lustik, Monty G. Marshall, Jay Ulfelder and Mark Woodward. 2010. "A Global Model for Forecasting Political Instability." American Journal of Political Science 54(1):190-208.

Gurr, Ted Robert. 1970. Why Men Rebel. Princeton, NJ: Princeton University Press.

Hadenius, Axel and Jan Teorell. 2007. "Pathways from Authoritarianism." Journal of Democracy 18(1):143-156.

Hegre, Håvard and Nicholas Sambanis. 2006. "Sensitivity Analysis of Empirical Results on Civil War Onset." Journal of Conflict Resolution 50(4):508-535.

Hegre, Håvard, Tanja Ellingsen, Scott Gates and Nils Petter Gleditsch. 2001. "Toward a Democratic Civil Peace? Democracy, Political Change, and Civil War, 1816-1992." American Political Science Review 95(1):33-48.

Hudson, Rex A. and Dennis M. Hanratty. 1991. Bolivia, a country study. Washington, D.C.: Research Division, Library of Congress.

Huntington, Samuel P. 1991. The Third Wave: Democratization in the Late Twentieth Century. Norman, OK: University of Oklahoma Press.

Kendall-Taylor, Andrea and Erica Frantz. 2014. "How Autocracies Fall." The Washington Quarterly 37(1):35-47.

Kennedy, Ryan. 2010. "The Contradiction of Modernization: A Conditional Model of Endogenous Democratization." The Journal of Politics 72(3):785-798.

Knutsen, Carl Henrik. 2014. "Income Growth and Revolutions." Social Science Quarterly 95(4):921-937.

Knutsen, Carl Henrik and Håvard Mokleiv Nygård. 2015. "Institutional characteristics and regime survival: Why are semi-democracies less durable than autocracies and democracies?" American Journal of Political Science 59(3):656-670.

Knutsen, Carl Henrik, Håvard Mokleiv Nygård and Tore Wig. 2017. "Autocratic Elections: Stabilizing Tool or Force for Change?" World Politics 69(1):98-143.

Knutsen, Carl Henrik, Jan Teorell, Agnes Cornell, John Gerring, Haakon Gjerløw, SvendErik Skaaning, Tore Wig, Daniel Ziblatt, Kyle Marquardt, Dan Pemstein and Brigitte Seim. 2017. "Introducing the Historical Varieties of Democracy Dataset: Patterns and Determinants of Democratization in the Long 19th Century." Working Paper. 
Knutsen, Carl Henrik, Jørgen Møller and Svend-Erik Skaaning. 2016. "Going Historical: Measuring Democraticness before the Age of Mass Democracy." International Political Science Review 37(5):679-689.

Kuran, Timur. 1989. "Sparks and Prairie Fires: A Theory of Unanticipated Political Revolution." Public Choice 61(1):41-74.

Linz, Juan J. 1990. "The Perils of Presidentialism." Journal of Democracy 1(1):51-69.

Lipset, Seymour Martin. 1959. "Some Social Requisites of Democracy: Economic Development and Political Legitimacy." American Political Science Review 53(1):69-105.

Magaloni, Beatriz. 2008. "Credible Power-Sharing and the Longevity of Authoritarian Rule." Comparative Political Studies 41(4-5):715-741.

Marshall, Monty G., Ted Robert Gurr and Keith Jaggers. 2013. "POLITY IV PROJECT: Political Regime Characteristics and Transitions, 1800-2012." Center for Systemic Peace. Codebook.

Moore, Barrington. 1966. Social Origins of Democracy and Dictatorship: Lord and Peasant in the Making of the Modern World. Boston: Beacon Press.

Ponticelli, Jacopo and Hans-Joachim Voth. 2011. "Austerity and Anarchy: Budget Cuts and Social Unrest in Europe, 1919-2008." Working Paper.

Powell, Jonathan. 2012. "Determinants of the Attempting and Outcome of Coups d'état." Journal of Conflict Resolution 56(6):1017-1040.

Powell, Jonathan M. and Clayton L. Thyne. 2011. "Global Instances of Coups from 1950Present: A New Dataset." Journal of Peace Research 48(2):249-259.

Przeworski, Adam and Fernando Limongi. 1997. "Modernization: Theory and Facts." World Politics 49(2):155-183.

Rapport, Mike. 2008. 1848. New York: Basic Books.

Roberts, Elizabeth. 2007. Realm of the Black Mountain: a history of Montenegro. Ithaca, NY: Cornell University Press.

Ross, Michael. 2012. The Oil Curse: How Petroleum Wealth Shapes the Development of Nations. Princeton: Princeton University Press.

Rubinstein, Alvin Z. 1981. "The Soviet Union and Iran under Khomeini." International Affairs 57(4):599-617.

Schatzberg, Michael G. 1997. "Beyond Mobutu: Kabila and the Congo." Journal of Democracy 8:70-84. 
Smith, Denis Mack. 1989. Italy and its Monarchy. New Haven: Yale University Press.

Svolik, Milan. 2008. "Authoritarian Reversals and Democratic Consolidation." American Political Science Review 102(2):153-168.

Svolik, Milan W. 2012. The Politics of Authoritarian Rule. Cambridge: Cambridge Univerisity Press.

Takeyh, Ray. 2014. "What really Happened in Iran: The CIA, the Ouster of Mosaddeq, and the Restoration of the Shah." Foreign Affairs 93(4):2-12.

Teorell, Jan. 2010. Determinants of Democracy: Explaining Regime Change in the World, 1972-2006. Cambridge: Cambridge University Press.

Teorell, Jan, Michael Coppedge, Svend-Erik Skaaning and Staffan I Lindberg. 2016. "Measuring electoral democracy with V-Dem data: Introducing a new polyarchy index." $V$-Dem Working Paper 25.

Vreeland, James Raymond. 2008. "The Effect of Political Regime on Civil War: Unpacking Anocracy." Journal of Conflict Resolution 52(3):401-425.

Zahrani, Mostafa T. 2002. "The Coup That Changed the Middle East. Mossadeq v. The CIA in Retrospect." World Policy Journal 19(2):93-99. 


\section{Online Appendices for: Patterns of Regime Breakdown since the French Revolution}

June 28, 2018 
These appendices contain additional information about the Historical Regimes Data (HRD) and some additional analyses not reported in the paper. More specifically, Appendix A lists all country-polity observations included in HRD as well as the wording of all the questions that were coded. Appendix B provides an overview of the data collection process and the division of labor within the team. Appendix $\mathrm{C}$ exemplifies the coding by presenting timelines as well as coding notes for a selected number of countries. Appendix D clarifies the use of the interregnum period coding in HRD.

The following appendices discuss key heuristics devised for the coding. Appendix E lists a number of events that are commonly used to identify candidates for regime breakdown as well as the thresholds applied for coding regime change and not for these events. Appendix F brings up, and specifies, the discussion of what to count as a "substantial change" to both formal and informal rules for leadership selection and maintenance, and goes through the key rules-of-thumb for determining this for the different regime end type categories. Appendix G clarifies and illustrates the considerations made when distinguishing between the three regime change categories that pertain to directed transitions or self-coups. Appendix $\mathrm{H}$ clarifies how the units (polities and their time series) are defined, and goes through different scenarios of regime change coding when polities merge or split up, including cases of decolonization.

Finally, Appendix I briefly illustrates results from a Bayesian change point model exercise, similar to that presented in the paper for all regime breakdowns, focusing only on regime breakdowns due to popular uprisings or only on regime breakdowns due to coups. 


\section{A Questions and observations included in HRD}

This appendix first lists the questions coded in HRD. Table A-1 at the end provides an overview of the polity-years included in the dataset. While HRD takes the definitions of country-units and time series from (Historical) V-Dem as its point of departure, please note that regimes that came to power before the start of the V-Dem time series, but controlled power at the first day of these time series, are also coded all the way back to the date the regime started. 


\section{Regime interregnum (v3regint)}

Question: Does there exist an identifiable political regime?

Clarification: This question is used to identify so-called interregnum periods, where no political regime is in control over the entity. Different types of political situations can lead to periods of time under which there is no identifiable political regime, one example being a civil war in which none of the parties have clear control over political bodies and processes in the country. However, the interregnum coding is employed conservatively, meaning that partial control over political bodies and processes in fairly large parts of the country (which is often the case also during civil wars) is sufficient for a 0 score.

0. Yes

1. No

\section{Regime name (v3regname)}

Question: What is the name of this regime?

Clarification: If the regime is commonly referred to with a particular name in the international literature, such as "The Second French Republic", then this name should be used. The exception to this rule is if the regime is only referred to by the name of the nation (e.g. "North Korean regime"). If multiple names are used interchangeably in the literature, select one of them. If there is no common name, try to provide a name that would be informative to scholars that have knowledge of the political history of the relevant country. If the time period in question is characterized by a so-called interregnum period, where no

political regime is coded, please provide the name "Interregnum $\mathrm{X}-\mathrm{Y}$ ", where $\mathrm{X}$ denotes the country and $\mathrm{Y}$ denotes the order (in time) of this interregnum period among all such periods (within the coded time series) for this particular country. E.g., the first coded interregnum period of Spain should be coded "Interregnum Spain-1".

Answer type: Text

Regime start date (v3regstartdate)

Question: When did the political regime obtain power?

Answer type: Day/Month/Year 


\section{Regime end date (v3regenddate)}

Question: When did the political regime lose power?

Answer type: Day/Month/Year

\section{Regime end type (v3regendtype)}

Question: Could you specify the types of processes (one or more) that led to the end of the regime?

0. A military coup d'etat.

1. A coup d'état conducted by other groups than the military.

2. A self-coup (autogolpe) conducted by the sitting leader.

3. Assassination of the sitting leader (but not related to a coup d'état)

4. Natural death of the sitting leader

5. Loss in civil war.

6. Loss in inter-state war.

7. Foreign intervention (other than loss in inter-state war)

8. Popular uprising.

9. Substantial political liberalization/democratization with some form of guidance by sitting regime leaders

10. Other type of directed and intentional transformational process of the regime under the guidance of sitting regime leaders (excluding political liberalization)

11. Substantial political liberalization/democratization without guidance by sitting regime leaders, occurring from some other process (such as an unexpected election loss for the sitting regime) than those specified by categories 1 to 10

12. Other process than those specified by categories 0 to 11 .

13. Regime still exists

Answer type: Single selection

\section{Regime end type, multiple selection (v3regendtypems)}

Question: Could you specify the type of process that you consider the most important in leading to the end of the regime? 
0. A military coup d'etat.

1. A coup d'état conducted by other groups than the military.

2. A self-coup (autogolpe) conducted by the sitting leader.

3. Assassination of the sitting leader (but not related to a coup d'état)

4. Natural death of the sitting leader

5. Loss in civil war.

6. Loss in inter-state war.

7. Foreign intervention (other than loss in inter-state war)

8. Popular uprising.

9. Substantial political liberalization/democratization with some form of guidance by sitting regime leaders

10. Other type of directed and intentional transformational process of the regime under the guidance of sitting regime leaders (excluding political liberalization)

11. Substantial political liberalization/democratization without guidance by sitting regime leaders, occurring from some other process (such as an unexpected election loss for the sitting regime) than those specified by categories 1 to 10

12. Other process than those specified by categories 0 to 11.

13. Regime still exists

Answer type: Multiple selection 


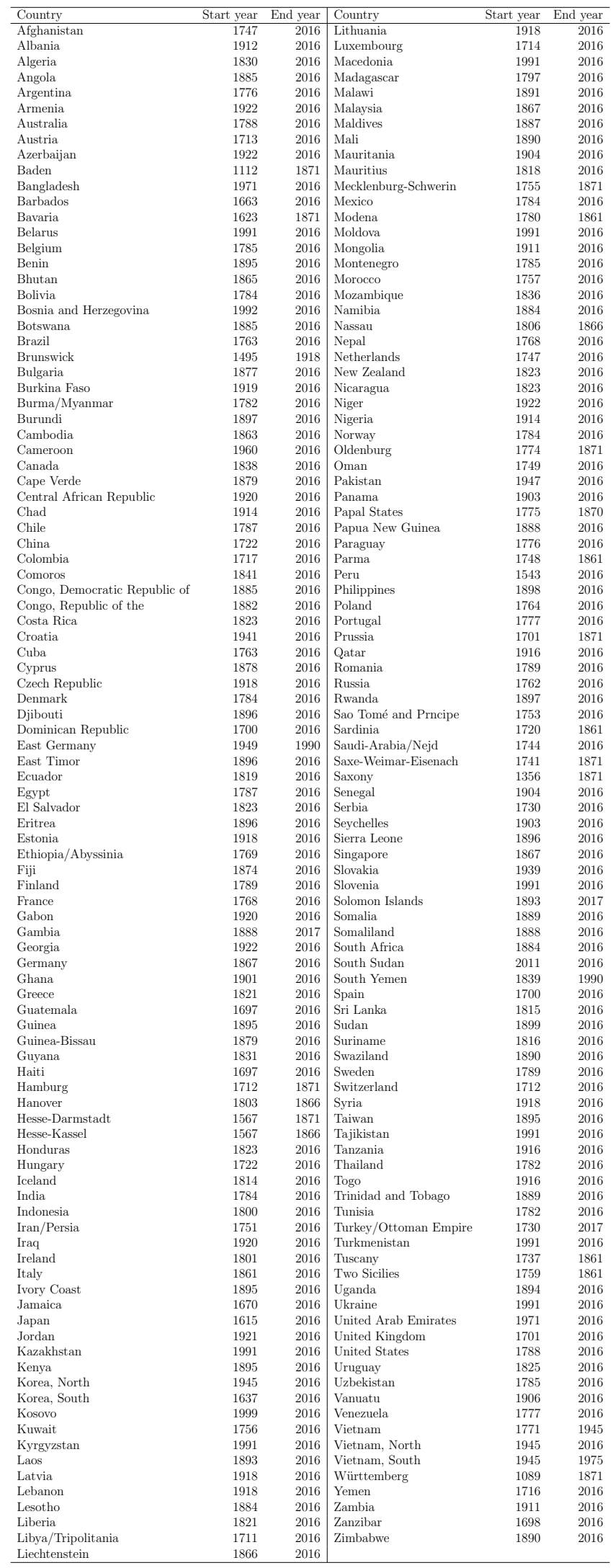

Table A-1: Observations included in HRD 


\section{B An overview of the data collection process}

Several scholars (from the Historical V-Dem team) were involved in the deliberation and revision of the questions and definitions employed for the Historical Regime Data (HRD), after they had been originally formulated by the second author of this article. The broader operational criteria guiding the data collection were intentionally designed to reflect the conceptual regime definition discussed in the paper. To recapitulate, a regime is defined according to the formal or informal rules for the selection and maintenance of political leaders in power.

Regarding the actual data collection, the second and third authors started by producing first drafts of the more specific coding guidelines and lists of operational criteria for the coding. They thereafter trial-coded a subset of eight (quite diverse) countries. They thereafter revised the coding scheme based on observations made during the trial coding, and recruited and coordinated the RAs' coding in a hands-on manner early on (another round of specifications of the operational criteria was conducted while and after the three RAs that were first recruited had completed their first batches of countries).

In the end, the first author of the article - originally one of the three first recruited RAs - conducted the main bulk of the coding, which lasted for about two years in total. The observations coded by the first author includes all coding for 1920-2016 for all polities (except for double-coding related to inter-coder reliability tests), in addition to a substantial part of the historical coding. She also trained additional RA coders and quality-controlled the coding of the other coders to enhance internal consistency, before "hard decisions" were passed on to the second and third author of the article. One important strategy in this regard was the explicit instruction given to all RAs that they should provide alternative codings, with full documentation for all alternative solutions, whenever in doubt on how to delineate the regime units. Typically, this would entail a more "liberal" coding, with one or more regime changes throughout a given time interval, as well as a more "conservative" coding where the entire time interval was covered by one regime. At the end of the historical coding and then again at the end of the coding for 1920-2016, the second and third authors would separately read through all these "liberal" / "conservative" codings, identify and read through additional source material if needed. The two authors would then make suggestions for decisions to these cases, with a particular focus on applying the rules so that cross-time and cross-country consistency was ensured, and meet for deliberations. In the very few cases were the two authors were unable to land on a joint decision, they would bring in the relevant RA for discussions and, if needed, ask the RA to go back to/identify more sources before 
settling the issue. More generally, internal consistency was also enhanced by continuous discussions between the authors and the RAs (and between the RAs), especially on how to settle dates, types of breakdown, and delineating regimes for tricky cases.

Among the RA coders, other than the first author, four focused on their respective batches of countries for the 1789-1920 period, with, e.g., one (Italian) RA coding Italian preunification states and one (German) RA coding German pre-unification states. All coders have drawn on several sources - mainly country-specific sources in the form of monographs written by historians or political scientists, research articles, or encyclopedias, but also crosscountry sources such as the existing regime datasets listed in the article - to inform their coding decisions.

The sixth RA double-coded six selected countries from Latin America across the 20th and 21st centuries - mainly countries that we presumed to be especially hard cases - for consistency/reliability checks. For these six countries (Bolivia, Costa Rica, Mexico, Uruguay, Venezuela and Nicaragua), the double-coder identified the exact regime end dates and end types recorded by the original coder for 75 percent of the originally coded regimes $(39 / 52)$. For another 10 percent ( 5 regimes), the double-coder identified the regime change dates identified by the original coder, but coded the end type differently. For the especially difficult case of Bolivia, 16 of the original coder's total of 22 regimes since the turn of the 20th century were exactly identified by the double-coder. As noted in the paper, the second coder, for instance, failed to identify two coups in the 1930s that the original coder had identified from one particular source (Hudson and Hanratty, 1991, 28-32). The first was the regime change following the military command's overthrow of president Salamanca during the Chaco War with Paraguay, leading to the instalment of his peace-seeking vice president. The second regime begins when a group of army officers decided to back the coup led by Col. Busch to overthrow president Toro in 1937, citing Toro's unwillingness to challenge the tin oligarchy as his main reason. For the more straightforward case of Costa Rica, however, the fifth coder identified the exact same four regimes as the original coder. 


\section{Examples of regime coding and coding notes}

In the paper, we provided an illustrative timeline of the coding of regime start- and end dates for Iran from 1925 onwards. Figure A-1 provides several other examples, covering the entire time series of the countries in question. At the same time, the timelines report how the various regimes ended. Specifically, we present time lines for Serbia, China, Mexico, France and Russia, with each regime death as recorded for the v3regendtype variable.

We then present tables with excerpts of the regime coding sheet for the set of countries in Figure A-1. These excerpts provide a brief historical exposition and justification for, for example, the coding of regime end dates of each regime. The full set of notes for all variables for each country can be found at ANONYMIZED WEBPAGE. 
Mexico

Russia

[8] [8] [10]

$[11] \quad[2]^{2017}$

$[8]$

$[8[10] \quad[0][10]$

$[6]$

$[8][2]$

$[6]$

$[6][6] \quad[10]$

France

Serbia

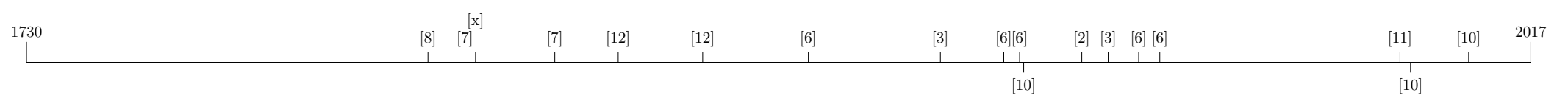

China

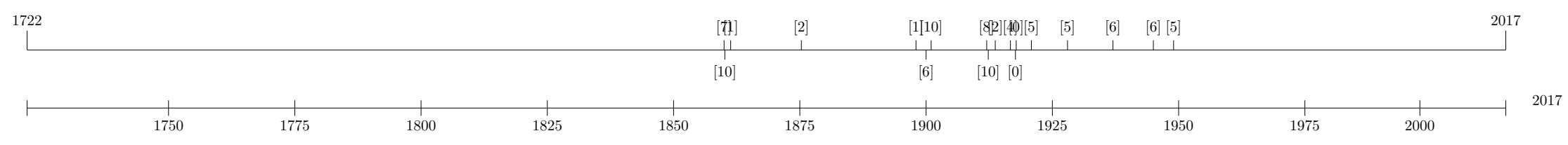

Note: $\mathrm{x}=$ Coding gap. $0=$ A military coup d'etat. $1=$ A coup d'etat conducted by other groups than the military. $2=$ A self-coup (autogolpe).

$3=$ Assassination of the sitting leader. $4=$ Natural death of the sitting leader. $5=$ Loss in civil war $6=$ Loss in inter-state war.

$10=$ Other type of direct $8=$ Popular uprising. $9=$ Substantial political liberalization with guidance by sitting regime.

$=$ Other type of directed transition with guidance of sitting regime. 11 = Substantial political liberalization without guidance by sitting regime. $12=$ Other process

Figure A-1: Time lines of HRD for Mexico, Russia, France, Serbia and China 


\begin{tabular}{|c|c|c|c|c|c|c|c|c|c|c|}
\hline $\begin{array}{l}\text { Country } \\
\text { name }\end{array}$ & $\begin{array}{l}\text { V-Dem } \\
\text { code }\end{array}$ & $\begin{array}{l}\text { Regime } \\
\text { name }\end{array}$ & v3regstartdate & & v3regenddate & Notes to v3regenddate & $\begin{array}{l}\text { v3regend- } \\
\text { typeMS }\end{array}$ & $\begin{array}{l}\text { v3regend- } \\
\text { type }\end{array}$ & Notes to v3regendtype & Sources \\
\hline Russia & 11 & $\begin{array}{l}\text { Early Impe- } \\
\text { rial Russia }\end{array}$ & $09 / 07 / 1762$ & 0 & $23 / 03 / 1801$ & $\begin{array}{l}\text { Military coup d'état against Paul. } \\
\text { After Paul was killed he was re- } \\
\text { placed by his son, Alexander I. }\end{array}$ & 0 & 0 & $\begin{array}{l}\text { Military coup d'état } \\
\text { against Paul. After } \\
\text { Paul was killed he } \\
\text { was replaced by his } \\
\text { son, Alexander I. }\end{array}$ & $\begin{array}{l}\text { Freeze }(2002: \\
\text { 115-116, 141). } \\
\text { Moss }(2005: \\
\text { 269, 333-334). } \\
\text { Encyclopedia } \\
\text { Britannica. }\end{array}$ \\
\hline Russia & 11 & $\begin{array}{l}\text { Late Impe- } \\
\text { rial Russia }\end{array}$ & $23 / 03 / 1801$ & 0 & $06 / 05 / 1906$ & $\begin{array}{l}\text { The empire's Fundamental Laws } \\
\text { were amended on May 6, 1906, } \\
\text { to take account of the Duma and } \\
\text { reforms promised in the October } \\
\text { Manifesto. }\end{array}$ & 8,9 & 8 & $\begin{array}{l}\text { Liberalization fol- } \\
\text { lowing the Revo- } \\
\text { lution of } 1905-06\end{array}$ & $\begin{array}{l}\text { Freeze (2002: } \\
\text { 215-220). Ri- } \\
\text { asanovsky and } \\
\text { Steinberg (2011: } \\
\text { 402-405). En- } \\
\text { cyclopedia } \\
\text { Britannica. }\end{array}$ \\
\hline Russia & 11 & $\begin{array}{l}\text { Post-1906 } \\
\text { Act }\end{array}$ & $06 / 05 / 1906$ & 0 & $11 / 03 / 1917$ & $\begin{array}{l}\text { Provisional government formed by } \\
\text { the Duma - and thus sidestepping } \\
\text { an imperial dissolution decree - as } \\
\text { a response to the February Revo- } \\
\text { lution of } 1917 \text {. }\end{array}$ & 8,11 & 8 & $\begin{array}{l}\text { Provisional gov- } \\
\text { ernment formed by } \\
\text { the Duma - and } \\
\text { thus sidestepping } \\
\text { an imperial disso- } \\
\text { lution decree - as } \\
\text { a response to the } \\
\text { February Revolution } \\
\text { of } 1917 \text {. }\end{array}$ & $\begin{array}{l}\text { Freeze (2002: } \\
\text { 235-240). Ri- } \\
\text { asanovsky and } \\
\text { Steinberg (2011: } \\
\text { 466-473). En- } \\
\text { cyclopedia } \\
\text { Britannica. }\end{array}$ \\
\hline Russia & 11 & $\begin{array}{l}\text { Provisional } \\
\text { government }\end{array}$ & $11 / 03 / 1917$ & 0 & $07 / 11 / 1917$ & $\begin{array}{l}\text { The Soviets seized control of } \\
\text { the government in November and } \\
\text { drove the provisional government } \\
\text { into exile, in the events that later } \\
\text { have become known as the Octo- } \\
\text { ber Revolution. }\end{array}$ & 8 & 8 & $\begin{array}{l}\text { Armed insurrec- } \\
\text { tion/uprising fol- } \\
\text { lowed by the disso- } \\
\text { lution of all vestiges } \\
\text { of democracy. }\end{array}$ & $\begin{array}{l}\text { Freeze }(2002: \\
247-257) . \text { Ri- } \\
\text { asanovsky and } \\
\text { Steinberg }(2011 \text { : } \\
475-477,488)\end{array}$ \\
\hline Russia & 11 & $\begin{array}{l}\text { Soviet } \\
\text { Russia }\end{array}$ & $07 / 11 / 1917$ & 0 & $30 / 12 / 1922$ & $\begin{array}{l}\text { Formation of the Union of Soviet } \\
\text { Socialist Republics. }\end{array}$ & 10 & 10 & $\begin{array}{l}\text { Formation of the } \\
\text { Union of Soviet } \\
\text { Socialist Republics. }\end{array}$ & $\begin{array}{l}\text { Riasanovsky } \\
\text { and Steinberg } \\
(2011: 500) \\
\text { Encyclopedia } \\
\text { Britannica. }\end{array}$ \\
\hline Russia & 11 & USSR & $30 / 12 / 1922$ & 0 & $31 / 12 / 1991$ & $\begin{array}{l}\text { The U.S.S.R. legally ceased to ex- } \\
\text { ist on December } 31,1991 .\end{array}$ & 11 & 11 & $\begin{array}{l}\text { Fall of Soviet coded } \\
\text { as political liber- } \\
\text { alization without } \\
\text { guidance by sitting } \\
\text { regime }\end{array}$ & Britannica \\
\hline
\end{tabular}




\begin{tabular}{|c|c|c|c|c|c|c|c|c|c|c|}
\hline $\begin{array}{l}\text { Country } \\
\text { name }\end{array}$ & $\begin{array}{l}\text { V-Dem } \\
\text { code }\end{array}$ & $\begin{array}{l}\text { Regime } \\
\text { name }\end{array}$ & v3regstartdate & & v3regenddate & Notes to v3regenddate & $\begin{array}{l}\text { v3regend- } \\
\text { typeMS }\end{array}$ & $\begin{array}{l}\text { v3regend- } \\
\text { type }\end{array}$ & Notes to v3regendtype & Sources \\
\hline Russia & 11 & $\begin{array}{l}\text { Post-Soviet } \\
\text { Russia }\end{array}$ & $31 / 12 / 1991$ & 0 & $21 / 09 / 1993$ & $\begin{array}{l}\text { On } 21 \text { Sept, Yeltsin issued a se- } \\
\text { ries of presidential decrees that } \\
\text { dissolved the parliament and im- } \\
\text { posed presidential rule that would } \\
\text { exist until after elections to a new } \\
\text { parliament and a referendum on a } \\
\text { new draft constitution were held. }\end{array}$ & 10,2 & 10 & $\begin{array}{l}\text { Directed transition } \\
\text { deemed most appro- } \\
\text { priate measure }\end{array}$ & Britannica \\
\hline Russia & 11 & $\begin{array}{l}\text { Russian } \\
\text { Federation }\end{array}$ & $21 / 09 / 1993$ & 0 & $04 / 03 / 2012$ & $\begin{array}{l}\text { Putin re-elected in very widely } \\
\text { fraudulent elections: end of 'man- } \\
\text { aged democracy' }\end{array}$ & 10,2 & 2 & $\begin{array}{l}\text { Directed transition, } \\
\text { but the development } \\
\text { overall deemed se- } \\
\text { vere enough to be } \\
\text { dubbed self-coup }\end{array}$ & $\begin{array}{l}\text { Britannica, } \\
\text { Krastev and } \\
\text { Holmes (2012) }\end{array}$ \\
\hline Russia & 11 & $\begin{array}{l}\text { Putin's } \\
\text { Russia }\end{array}$ & $04 / 03 / 2012$ & 0 & $\mathrm{E}$ & & & & & $\begin{array}{l}\text { Britannica, } \\
\text { Krastev and } \\
\text { Holmes (2012) }\end{array}$ \\
\hline Serbia & 198 & $\begin{array}{l}\text { Ottoman } \\
\text { Empire - } \\
\text { Mahmud I - } \\
\text { Selim III }\end{array}$ & $28 / 09 / 1730$ & 1 & $15 / 12 / 1806$ & $\begin{array}{l}\text { Though the first Serbian Upris- } \\
\text { ing started in } 1804 \text {, actual seize } \\
\text { of Belgrade did not succeed until } \\
1806 \text { (Stavrianos 1963) }\end{array}$ & 8 & 8 & $\begin{array}{l}\text { Popular uprising led } \\
\text { by Karadjordje }\end{array}$ & $\begin{array}{l}\text { Britannica, } \\
\text { Stavrianos } \\
2000: 19-20, \\
\text { Wikipedia }\end{array}$ \\
\hline Serbia & 198 & $\begin{array}{l}\text { Serbian } \\
\text { nationalist } \\
\text { uprising }\end{array}$ & $15 / 12 / 1806$ & 1 & $15 / 12 / 1813$ & Ottomans retake Belgrade & 6,7 & 7 & $\begin{array}{l}\text { Coded foreign inter- } \\
\text { vention because the } \\
\text { Ottoman Empire } \\
\text { was ultimately de- } \\
\text { cisive in reclaiming } \\
\text { Serbia. }\end{array}$ & $\begin{array}{l}\text { Britannica, } \\
\text { Stavrianos } \\
\text { 1963:21-22, } \\
\text { Mazover 2000:83, } \\
\text { Wikipedia }\end{array}$ \\
\hline Serbia & 198 & $\begin{array}{l}\text { Not to be } \\
\text { coded }\end{array}$ & $15 / 12 / 1813$ & 1 & $15 / 04 / 1815$ & & & & & \\
\hline Serbia & 198 & $\begin{array}{l}\text { The Obren- } \\
\text { ovich Ot- } \\
\text { toman } \\
\text { Principality } \\
\text { of Serbia }\end{array}$ & $15 / 04 / 1815$ & 1 & $01 / 01 / 1830$ & $\begin{array}{l}\text { After a period of Russian- } \\
\text { Ottoman war, the Ottoman } \\
\text { empire granted Serbia full au- } \\
\text { tonomy (Britannica). Sources } \\
\text { disagree on the importance of } \\
1830 \text {; Stavrianos treating } 1815 \\
\text { as year of full autonomy, whilst } \\
\text { Britannica and Mazover see the } \\
\text { change as substantial. }\end{array}$ & 7 & 7 & $\begin{array}{l}\text { Ottoman Empire } \\
\text { grants autonomy }\end{array}$ & $\begin{array}{l}\text { Britannica, } \\
\text { Stavrianos } \\
\text { 1963:21-22, } \\
\text { Mazover 2000:83, } \\
\text { Wikipedia }\end{array}$ \\
\hline
\end{tabular}




\begin{tabular}{|c|c|c|c|c|c|c|c|c|c|c|}
\hline $\begin{array}{l}\text { Country } \\
\text { name }\end{array}$ & $\begin{array}{l}\text { V-Dem } \\
\text { code }\end{array}$ & $\begin{array}{l}\text { Regime } \\
\text { name }\end{array}$ & v3regstartdate & & v3regenddate & Notes to v3regenddate & $\begin{array}{l}\text { v3regend- } \\
\text { typeMS }\end{array}$ & $\begin{array}{l}\text { v3regend- } \\
\text { type }\end{array}$ & Notes to v3regendtype & Sources \\
\hline Serbia & 198 & $\begin{array}{l}\text { The Obren- } \\
\text { ovich Au- } \\
\text { tonomous } \\
\text { Ottoman } \\
\text { Principality } \\
\text { of Serbia }\end{array}$ & $01 / 01 / 1830$ & 1 & $14 / 09 / 1842$ & $\begin{array}{l}\text { National Assembly (Skupshtina) } \\
\text { ousts Obrenovich and elects } \\
\text { Karadjordje's son Alexander } \\
\text { as prince of the principality. } \\
\text { Argument for regime change: } \\
\text { Britannica and Stavrianos (1963) } \\
\text { describe a power struggle between } \\
\text { supporters of the Obrenovich and } \\
\text { Karadjordjevich clans throughout } \\
\text { the period 1815-WWII. }\end{array}$ & 12 & 12 & $\begin{array}{l}\text { Election in Skup- } \\
\text { shtina, but not } \\
\text { democratization - } \\
\text { rather represen- } \\
\text { tation of power } \\
\text { struggle between } \\
\text { the clans and Na- } \\
\text { tional Assembly } \\
\text { dissatisfaction with } \\
\text { Obrenovich. }\end{array}$ & $\begin{array}{l}\text { Britannica, } \\
\text { Stavrianos } \\
1963: 22, \\
\text { Wikipedia }\end{array}$ \\
\hline Serbia & 198 & $\begin{array}{l}\text { Karad- } \\
\text { jordjevic } \\
\text { Principality } \\
\text { of Serbia }\end{array}$ & $14 / 09 / 1842$ & 0 & $23 / 12 / 1858$ & $\begin{array}{l}\text { The Skupshtina ousted Karad- } \\
\text { jordjevich in favour of Obren- } \\
\text { ovich. }\end{array}$ & 12 & 12 & $\begin{array}{l}\text { Election in Skup- } \\
\text { shtina, but not } \\
\text { democratization - } \\
\text { rather represen- } \\
\text { tation of power } \\
\text { struggle between } \\
\text { the clans and Na- } \\
\text { tional Assembly } \\
\text { dissatisfaction with } \\
\text { Obrenovich. }\end{array}$ & $\begin{array}{l}\text { Britannica, } \\
\text { Stavrianos } \\
1963: 22, \\
\text { Wikipedia }\end{array}$ \\
\hline Serbia & 198 & $\begin{array}{l}\text { Obrenovic } \\
\text { Principality } \\
\text { of Serbia }\end{array}$ & $23 / 12 / 1858$ & 0 & $13 / 07 / 1878$ & $\begin{array}{l}\text { The Serbs declared war against } \\
\text { the Ottoman Empire in } 1876 \text {, and } \\
\text { the war was ended by first the } \\
\text { Treaty of San Stefano (May } 1878) \text {, } \\
\text { and then the Treaty of Berlin } \\
\text { (13/07/1878) which ensured Ser- } \\
\text { bia complete and final indepen- } \\
\text { dence from the Ottoman Empire. } \\
\text { The Kingdom of Serbia then came } \\
\text { into being within the following } \\
\text { couple of years, and was formally } \\
\text { established in } 1882 \text { when Prince } \\
\text { Milan Obrenovich was crowned } \\
\text { King of Serbia (Wikipedia). }\end{array}$ & 6 & 6 & $\begin{array}{l}\text { Coded loss in inter- } \\
\text { state war because } \\
\text { the Ottoman Em- } \\
\text { pire lost against the } \\
\text { Serbs and granted } \\
\text { autonomy in the } \\
\text { treaty of Berlin. }\end{array}$ & $\begin{array}{l}\text { Britannica, } \\
\text { Stavrianos } \\
\text { 1963:22-25, } \\
\text { Wikipedia }\end{array}$ \\
\hline Serbia & 198 & $\begin{array}{l}\text { Obrenovich } \\
\text { Kingdom of } \\
\text { Serbia }\end{array}$ & $13 / 07 / 1878$ & 0 & $15 / 06 / 1903$ & $\begin{array}{l}\text { King Alexander Obrenovich is as- } \\
\text { sasinated by officers in the na- } \\
\text { tional assembly and Peter Karad- } \\
\text { jordjevic is invited to take back } \\
\text { the throne (Britannica). His in- } \\
\text { aguration marks the date. }\end{array}$ & 3 & 3 & $\begin{array}{l}\text { Obrenovich is assas- } \\
\text { inated }\end{array}$ & $\begin{array}{l}\text { Britannica, } \\
\text { Conley } 2012\end{array}$ \\
\hline
\end{tabular}




\begin{tabular}{|c|c|c|c|c|c|c|c|c|c|c|}
\hline $\begin{array}{l}\text { Country } \\
\text { name }\end{array}$ & $\begin{array}{l}\text { V-Dem } \\
\text { code }\end{array}$ & $\begin{array}{l}\text { Regime } \\
\text { name }\end{array}$ & v3regstartdate & & v3regenddate & Notes to v3regenddate & $\begin{array}{l}\text { v3regend- } \\
\text { typeMS }\end{array}$ & $\begin{array}{l}\text { v3regend- } \\
\text { type }\end{array}$ & Notes to v3regendtype & Sources \\
\hline Serbia & 198 & $\begin{array}{l}\text { Karad- } \\
\text { jordjevich } \\
\text { Kingdom of } \\
\text { Serbia }\end{array}$ & $15 / 06 / 1903$ & 0 & $15 / 10 / 1915$ & $\begin{array}{l}\text { In October } 1915 \text {, the German gen- } \\
\text { eral von Mackensen launched a } \\
\text { third offensive, supported by the } \\
\text { Bulgarian army, and effectively } \\
\text { forced the Serbs to retreat across } \\
\text { Albania to the Adriatic Coast. }\end{array}$ & 6 & 6 & Loss in WWI & $\begin{array}{l}\text { Britannica, } \\
\text { Wikipedia, } \\
\text { Conley } 2012\end{array}$ \\
\hline Serbia & 198 & $\begin{array}{l}\text { Austrian- } \\
\text { Hungarian } \\
\text { occupation } \\
\text { of Serbia }\end{array}$ & $15 / 10 / 1915$ & 1 & $01 / 11 / 1918$ & $\begin{array}{l}\text { Belgrade was recaptured by } \\
\text { British, French, Greek and Serb } \\
\text { forces, and Austria-Hungary } \\
\text { agreed to an armistice. }\end{array}$ & 6 & 6 & Loss in WWI & Britannica \\
\hline Serbia & 198 & $\begin{array}{l}\text { Kingdom of } \\
\text { Serbia }\end{array}$ & $01 / 11 / 1918$ & 0 & $01 / 12 / 1918$ & $\begin{array}{l}\text { In November } 1918 \text {, the Yugoslav } \\
\text { Comittee had met in Geneva, fol- } \\
\text { lowed by Zagreb severing of ties } \\
\text { to Hungary and the agreement } \\
\text { of a Union. On } 1 / 12 / 1918 \text { the } \\
\text { prince regent Alexander was in- } \\
\text { vited to problaim the new union. } \\
\text { On } 5 \text { Dec, the Kingdom of Serbs, } \\
\text { Croats and Slovenes was pre- } \\
\text { sented to the world. }\end{array}$ & 10 & 10 & $\begin{array}{l}\text { The reigning Peter } \\
\text { I joins Serbs and } \\
\text { Croats in creating } \\
\text { the Kingdom of } \\
\text { Serbs, Croats and } \\
\text { Slovenes }\end{array}$ & $\begin{array}{l}\text { Britannica, } \\
\text { Wikipedia }\end{array}$ \\
\hline Serbia & 198 & $\begin{array}{l}\text { Kingdom } \\
\text { of Serbs, } \\
\text { Croats and } \\
\text { Slovenes }\end{array}$ & $01 / 12 / 1918$ & 0 & $06 / 01 / 1929$ & $\begin{array}{l}\text { King Peter I dies at the age of } \\
77 \text { in } 1921 . \text { The } 20 \text { s were then } \\
\text { tainted by cooperational chal- } \\
\text { lenges in the Skupshtina and the } \\
\text { conflict climaxed when the Serb } \\
\text { deputy Racic shot and killed three } \\
\text { members of the opposition Croa- } \\
\text { tian Peasant Party. On } 6 \text { Jan } \\
1929 \text {, King Alexander I suspended } \\
\text { the constitution and established } \\
\text { a monarchic dictatorship with the } \\
\text { new name Yugoslavia (Britannica } \\
\text { and Wikipedia) }\end{array}$ & 2 & 2 & $\begin{array}{l}\text { King Alexander I re- } \\
\text { acts to the turmoil } \\
\text { of the Skupshtina by } \\
\text { declaring a royal dic- } \\
\text { tatorship. }\end{array}$ & $\begin{array}{l}\text { Britannica, } \\
\text { Wikipedia }\end{array}$ \\
\hline Serbia & 198 & $\begin{array}{l}\text { King } \\
\text { Alexan- } \\
\text { der's dicta- } \\
\text { torship of } \\
\text { Yugoslavia }\end{array}$ & $06 / 01 / 1929$ & 0 & $09 / 10 / 1934$ & $\begin{array}{l}\text { Alexander's reign was only par- } \\
\text { tially supported and eventually } \\
\text { gained large opposition. When } \\
\text { the King was on an official visit } \\
\text { to France, he was assasinated on } \\
9 \text { Oct } 1934 \text {. A regency was estab- } \\
\text { lished, headed by Prince Paul, the } \\
\text { uncle of Peter II, the heir to the } \\
\text { throne. }\end{array}$ & 3 & 3 & $\begin{array}{l}\text { Assassination of } \\
\text { Alexander }\end{array}$ & $\begin{array}{l}\text { Britannica, } \\
\text { Wikipedia, } \\
\text { Lampe 1996:160- } \\
197\end{array}$ \\
\hline
\end{tabular}




\begin{tabular}{|c|c|c|c|c|c|c|c|c|c|c|}
\hline $\begin{array}{l}\text { Country } \\
\text { name }\end{array}$ & $\begin{array}{l}\text { V-Dem } \\
\text { code }\end{array}$ & $\begin{array}{l}\text { Regime } \\
\text { name }\end{array}$ & v3regstartdate & & v3regenddate & Notes to v3regenddate & $\begin{array}{l}\text { v3regend- } \\
\text { typeMS }\end{array}$ & $\begin{array}{l}\text { v3regend- } \\
\text { type }\end{array}$ & Notes to v3regendtype & Sources \\
\hline Serbia & 198 & $\begin{array}{l}\text { Kingdom of } \\
\text { Yugoslavia: } \\
\text { Prince Paul }\end{array}$ & 09/10/1934 & 0 & 06/04/1941 & $\begin{array}{l}\text { Discussions between the Serb } \\
\text { leader Dragia Cvetkovi and } \\
\text { Croatian Peasant Party leader } \\
\text { Vladimir Macek resulted in the } \\
\text { Sporazum (Agreement) of August } \\
\text { 1939, on the eve of World War } \\
\text { II, which made provision for an } \\
\text { enlarged, partially self-governing } \\
\text { Croatian banovina. Whether this } \\
\text { prefigured a peaceful reconcili- } \\
\text { ation of the Serb-Croat conflict } \\
\text { remains unclear, as Yugoslavia } \\
\text { was invaded and broken up by } \\
\text { Nazi Germany and its allies in } \\
\text { April 1941. }\end{array}$ & 6 & 6 & $\begin{array}{l}\text { Loss to Axis powers } \\
\text { in WWII }\end{array}$ & $\begin{array}{l}\text { Britannica, } \\
\text { Wikipedia, } \\
\text { Lampe 1996:160- } \\
197\end{array}$ \\
\hline Serbia & 198 & $\begin{array}{l}\text { German/ } \\
\text { Italian } \\
\text { occupied } \\
\text { Yugoslavia }\end{array}$ & 06/04/1941 & 0 & $12 / 04 / 1945$ & $\begin{array}{l}\text { The occupation started to come } \\
\text { to an end in Serbia in } 1944 \text {, and } \\
\text { the eventual and complete end of } \\
\text { occupied Yugoslavia came when } \\
\text { Yugoslav partisans and the Red } \\
\text { Army broke the Syrmian front on } \\
12 \text { April } 1945 .\end{array}$ & 6 & 6 & $\begin{array}{l}\text { Axis powers defeat } \\
\text { in WWII }\end{array}$ & $\begin{array}{l}\text { Britannica, } \\
\text { Wikipedia, } \\
\text { Lampe 1996:223- } \\
230\end{array}$ \\
\hline Serbia & 198 & $\begin{array}{l}\text { SFR Yu- } \\
\text { goslavia }\end{array}$ & $12 / 04 / 1945$ & 0 & $22 / 01 / 1990$ & $\begin{array}{l}\text { When the ruling Communist } \\
\text { League dissolved in January 1990, } \\
\text { Serbia (including the territories } \\
\text { of Montenegro and Kosovo) con- } \\
\text { tained their status as Republic } \\
\text { of Serbia within Yugoslavia, but } \\
\text { now without Communist rule. }\end{array}$ & 12,11 & 11 & $\begin{array}{l}\text { The dissolution } \\
\text { of the Communist } \\
\text { League is credited to } \\
\text { an array of factors. } \\
\text { Economic inequal- } \\
\text { ity and decline, } \\
\text { popular discontent, } \\
\text { rising nation- } \\
\text { alist/separatist } \\
\text { sentiments and the } \\
\text { rise of Milosevic } \\
\text { all included. The } \\
\text { change is coded } \\
\text { liberalization with- } \\
\text { out guidance of } \\
\text { regime leaders be- } \\
\text { cause of the abrupt } \\
\text { dissolution of the } \\
\text { party - although } \\
\text { democracy did not } \\
\text { prevail in most of } \\
\text { the Post-Yugoslav } \\
\text { countries. }\end{array}$ & $\begin{array}{l}\text { Britannica, } \\
\text { Wikipedia, } \\
\text { Lampe 1996:344- } \\
345\end{array}$ \\
\hline
\end{tabular}




\begin{tabular}{|c|c|c|c|c|c|c|c|c|c|c|}
\hline $\begin{array}{l}\text { Country } \\
\text { name }\end{array}$ & $\begin{array}{l}\text { V-Dem } \\
\text { code }\end{array}$ & $\begin{array}{l}\text { Regime } \\
\text { name }\end{array}$ & v3regstartdate & & v3regenddate & Notes to v3regenddate & $\begin{array}{l}\text { v3regend- } \\
\text { typeMS }\end{array}$ & $\begin{array}{l}\text { v3regend- } \\
\text { type }\end{array}$ & Notes to v3regendtype & Sources \\
\hline Serbia & 198 & $\begin{array}{l}\text { Republic } \\
\text { of Serbia } \\
\text { within } \\
\text { Yugoslavia }\end{array}$ & $22 / 01 / 1990$ & 0 & $27 / 04 / 1992$ & $\begin{array}{l}\text { On April 27, 1992, a new Fed- } \\
\text { eral Republic of Yugoslavia was } \\
\text { inaugurated, comprising only Ser- } \\
\text { bia and Montenegro. Its capi- } \\
\text { tal and assembly were both placed } \\
\text { in Belgrade. The new state was } \\
\text { not recognized by the entire in- } \\
\text { ternational community, however, } \\
\text { because of its continued military } \\
\text { involvement in other republics of } \\
\text { the former Yugoslavia (Britan- } \\
\text { nica) }\end{array}$ & 10 & 10 & $\begin{array}{lr}\text { Directed } & \text { transfor- } \\
\text { mational } & \text { process } \\
\text { by sitting } & \text { regime } \\
\text { leaders } & \end{array}$ & $\begin{array}{l}\text { Britannica, } \\
\text { Lampe 1996:344- } \\
\text { 345, Blum (1992) }\end{array}$ \\
\hline Serbia & 198 & $\begin{array}{l}\text { Serbia part } \\
\text { of Federal } \\
\text { Republic of } \\
\text { Yugoslavia }\end{array}$ & $27 / 04 / 1992$ & 0 & $04 / 02 / 2003$ & $\begin{array}{l}\text { Despite widespread support for } \\
\text { independence in Montenegro and } \\
\text { plans to hold a referendum on se- } \\
\text { cession in April 2002, jukanovi ne- } \\
\text { gotiated an agreement with Yu- } \\
\text { goslav and Serbian authorities in } \\
\text { March, calling for Montenegros } \\
\text { continued association with Serbia } \\
\text { in a virtual federation. The agree- } \\
\text { ment, approved by the Yugoslav } \\
\text { parliament and the Montenegrin } \\
\text { and Serbian assemblies in 2003, } \\
\text { renamed the country Serbia and } \\
\text { Montenegro, gave wide powers to } \\
\text { the governments of Montenegro } \\
\text { and Serbia, and allowed each re- } \\
\text { public to hold a referendum on in- } \\
\text { dependence and to withdraw from } \\
\text { the union after three years (Bri- } \\
\text { tannica). }\end{array}$ & 10 & 10 & $\begin{array}{lr}\text { Directed } & \text { transfor- } \\
\text { mational } & \text { process } \\
\text { by sitting } & \text { regime } \\
\text { leaders } & \end{array}$ & $\begin{array}{l}\text { Britannica, Blum } \\
\text { (1992), enddate } \\
\text { from Wikipedia }\end{array}$ \\
\hline Serbia & 198 & $\begin{array}{l}\text { Confed- } \\
\text { eration of } \\
\text { Serbia and } \\
\text { Montenegro }\end{array}$ & $04 / 02 / 2003$ & 0 & $\mathrm{E}$ & $\begin{array}{l}\text { Kosovo declares independence in } \\
2008 \text {, but its independence is not } \\
\text { recognized by Serbia. }\end{array}$ & & & & $\begin{array}{l}\text { Britannica, } \\
\text { startdate from } \\
\text { Wikipedia }\end{array}$ \\
\hline Mexico & 3 & $\begin{array}{l}\text { General } \\
\text { Comman- } \\
\text { dancy of } \\
\text { the Internal } \\
\text { Provinces }\end{array}$ & $01 / 01 / 1784$ & 1 & $15 / 09 / 1808$ & $\begin{array}{l}\text { On } 15 \text { September, defenders of } \\
\text { the Empire, mostly European } \\
\text { Spaniards, use force to put the } \\
\text { Viceroy and the supporters of } \\
\text { home rule in jail. }\end{array}$ & 1 & 1 & $\begin{array}{l}\text { Spanish peninsulars } \\
\text { and their army } \\
\text { units assure im- } \\
\text { perial interests by } \\
\text { putting vieceregal } \\
\text { authorities in jail. } \\
\text { Considered a coup. }\end{array}$ & $\begin{array}{l}\text { Guedea (2000: } \\
277-282,285-286)\end{array}$ \\
\hline
\end{tabular}




\begin{tabular}{|c|c|c|c|c|c|c|c|c|c|c|}
\hline $\begin{array}{l}\text { Country } \\
\text { name }\end{array}$ & $\begin{array}{l}\text { V-Dem } \\
\text { code }\end{array}$ & $\begin{array}{l}\text { Regime } \\
\text { name }\end{array}$ & v3regstartdate & & v3regenddate & Notes to v3regenddate & $\begin{array}{l}\text { v3regend- } \\
\text { typeMS }\end{array}$ & $\begin{array}{l}\text { v3regend- } \\
\text { type }\end{array}$ & Notes to v3regendtype & Sources \\
\hline Mexico & 3 & $\begin{array}{l}\text { New } \\
\text { Spain/Supreme } \\
\text { Governing } \\
\text { Central } \\
\text { Junta }\end{array}$ & $15 / 09 / 1808$ & 0 & $15 / 09 / 1812$ & $\begin{array}{l}\text { An uprising sparked by the priest } \\
\text { Miguel Hidalgo cryout against the } \\
\text { rule of Spanish peninsulars leads } \\
\text { to a bloo, but they are not yet } \\
\text { able to seriously challenge the au- } \\
\text { thority of the colonial power. In } \\
\text { Septemer } 1812 \text { New Spain promul- } \\
\text { gates the liberal Spanish constitu- } \\
\text { tion of Cadiz. }\end{array}$ & 9 & 9 & $\begin{array}{l}\text { New Spain promul- } \\
\text { gates a liberal con- } \\
\text { stitution drawn up } \\
\text { by the Cortes in } \\
\text { Cadiz. The consti- } \\
\text { tution has a direct } \\
\text { impa. }\end{array}$ & $\begin{array}{l}\text { Guedea (2000: } \\
286-294) ; \text { Ham- } \\
\text { nett (1999: } \\
134-137)\end{array}$ \\
\hline Mexico & 3 & $\begin{array}{l}1912 \text { Con- } \\
\text { stitution of } \\
\text { Cdiz }\end{array}$ & $15 / 09 / 1812$ & 1 & $22 / 03 / 1814$ & $\begin{array}{l}\text { The colonial powerholders in New } \\
\text { Spain adopt the constitution sig- } \\
\text { nifiying allegiance to Spain. But } \\
\text { in effect the constitution gives } \\
\text { opportunities for the home rule } \\
\text { movement to be elected to every- } \\
\text { thing from local councils to the } \\
\text { Cortes in Cadiz. Giving ayun- } \\
\text { tamientos formal power is a threat } \\
\text { to colonial rule. }\end{array}$ & 10 & 10 & $\begin{array}{l}\text { Considered intended } \\
\text { transformational } \\
\text { process in which } \\
\text { the colonial admin- } \\
\text { istration follows } \\
\text { the decrees of the } \\
\text { newly reinstated } \\
\text { Ferdinand VII. }\end{array}$ & $\begin{array}{l}\text { Guedea (2000: } \\
\text { 292-295); Ham- } \\
\text { nett (1999: } \\
139-141)\end{array}$ \\
\hline Mexico & 3 & $\begin{array}{l}\text { New Spain } \\
\text { under } \\
\text { Viceroy Felix } \\
\text { Maria del } \\
\text { Rey/Viceroy } \\
\text { Juan Ruiz de } \\
\text { Apodaca }\end{array}$ & $22 / 03 / 1814$ & 0 & $15 / 09 / 1820$ & $\begin{array}{l}\text { Efforts to organize the insurgency } \\
\text { endures and the condition of New } \\
\text { Spain runs parrallel to events tak- } \\
\text { ing place in Spain. A strug- } \\
\text { gle between constitutionalists and } \\
\text { royalists lead to restoration of } \\
\text { the constitution of } 1812 \text { in Spain. } \\
\text { By September } 1820 \text {, the constitu- } \\
\text { tional system is restored in New } \\
\text { Spain. }\end{array}$ & 9 & 9 & $\begin{array}{l}\text { The constitution } \\
\text { enunciates a liberal } \\
\text { bill of rights, and } \\
\text { provides for the } \\
\text { reestablishment of } \\
\text { constitutional ayun- } \\
\text { tamientos (munic- } \\
\text { ipal governments). } \\
\text { Considered political } \\
\text { liberalization. }\end{array}$ & $\begin{array}{l}\text { Guedea (2000: } \\
\text { 294-296); Meyer } \\
\text { and Sherman } \\
(1995: 291-294)\end{array}$ \\
\hline Mexico & 3 & $\begin{array}{l}\text { Constitu- } \\
\text { tional regime } \\
\text { based n con- } \\
\text { stitution of } \\
1812\end{array}$ & $15 / 09 / 1820$ & 1 & $28 / 09 / 1821$ & $\begin{array}{l}\text { The disintegration of colonial } \\
\text { viceregal power in Mexico City, } \\
\text { the restoration of the constitu- } \\
\text { tion, turmoil in Spain and the } \\
\text { Cortes in Madrid's delaying tak- } \\
\text { ing action on colonial questions, } \\
\text { lead the majority of New Spain } \\
\text { to desire freedom from Spain's } \\
\text { volatile politics. This creates an } \\
\text { independence movement quite dif- } \\
\text { ferent from the insurgency move- } \\
\text { ment of } 1810 \text {. }\end{array}$ & 8 & 8 & $\begin{array}{l}\text { Considered popular } \\
\text { uprising in which } \\
\text { New Spaniards from } \\
\text { most segments of } \\
\text { society join in the } \\
\text { proclamation of } \\
\text { independence from } \\
\text { Spain. }\end{array}$ & $\begin{array}{l}\text { Guedea (2000: } \\
\text { 295-298); Meyer } \\
\text { and Sherman } \\
\text { (1995: 294-297); } \\
\text { Hamnett (1999: } \\
\text { 140-143) }\end{array}$ \\
\hline
\end{tabular}




\begin{tabular}{|c|c|c|c|c|c|c|c|c|c|c|}
\hline $\begin{array}{l}\text { Country } \\
\text { name }\end{array}$ & $\begin{array}{l}\text { V-Dem } \\
\text { code }\end{array}$ & $\begin{array}{l}\text { Regime } \\
\text { name }\end{array}$ & v3regstartdate & & v3regenddate & Notes to v3regenddate & $\begin{array}{l}\text { v3regend- } \\
\text { typeMS }\end{array}$ & $\begin{array}{l}\text { v3regend- } \\
\text { type }\end{array}$ & Notes to v3regendtype & Sources \\
\hline Mexico & 3 & $\begin{array}{l}\text { The Mexican } \\
\text { Em- } \\
\text { pire/Suprema } \\
\text { Junta Pro- } \\
\text { visional } \\
\text { Gubernativa }\end{array}$ & $28 / 09 / 1821$ & 0 & $19 / 05 / 1822$ & $\begin{array}{l}\text { In May the Mexican Cortes } \\
\text { convenes and chooses Iturbide as } \\
\text { monarch after a staged demon- } \\
\text { stration in Mexico City by royalist } \\
\text { Junta members. }\end{array}$ & 10,1 & 10 & $\begin{array}{l}\text { Could be considered } \\
\text { intended transfor- } \\
\text { mational process } \\
\text { by the Junta and } \\
\text { Congress, or an or- } \\
\text { chestrated coup by } \\
\text { followers of Iturbide. }\end{array}$ & $\begin{array}{l}\text { Meyer and } \\
\text { Sherman (1995: } \\
\text { 294-296); Guedea } \\
\text { (2000: 296-301); } \\
\text { Hamnett (1999: } \\
\text { 143-145) }\end{array}$ \\
\hline Mexico & 3 & $\begin{array}{l}\text { The Mexican } \\
\text { Empire/ } \\
\text { Consti- } \\
\text { tutional } \\
\text { Emperor } \\
\text { Agustin I }\end{array}$ & $19 / 05 / 1822$ & 0 & $31 / 10 / 1822$ & $\begin{array}{l}\text { The inherent contradiction in the } \\
\text { system leads to deepening con- } \\
\text { flict between Congress and the } \\
\text { executive. The Junta, now } \\
\text { dominated by conservatives in- } \\
\text { terests, declares itself not to be } \\
\text { bound by the constitution. Many } \\
\text { in Congress do not accomodate } \\
\text { themselves to the idea of monar- } \\
\text { chical Mexico and it is unaccept- } \\
\text { able to provincial and local au- } \\
\text { thorities. Iturbide and the Junta } \\
\text { start to suppress opposition, and } \\
\text { in October he dissolves Congress. }\end{array}$ & 2 & 2 & $\begin{array}{l}\text { Considered au- } \\
\text { tocoup in which } \\
\text { Iturbide dissolves } \\
\text { the legislature and } \\
\text { gives power to } \\
\text { a self-appointed } \\
\text { Junta. }\end{array}$ & $\begin{array}{l}\text { Meyer and } \\
\text { Sherman (1995: } \\
\text { 305-307); Archer } \\
(2000: 316) ; \\
\text { Hamnett (1999: } \\
\text { 144) }\end{array}$ \\
\hline Mexico & 3 & $\begin{array}{l}\text { The Mexican } \\
\text { Empire/ } \\
\text { Emperor } \\
\text { Agustiin I }\end{array}$ & $31 / 10 / 1822$ & 0 & $15 / 02 / 1823$ & $\begin{array}{l}\text { Agustin's arbitrary rule provides } \\
\text { a pretext for revolt. One of the re- } \\
\text { volt leaders, commander Antonio } \\
\text { Lpez de Santa Anna proclaim that } \\
\text { Mexico should become a republic, } \\
\text { and is joined by several provin- } \\
\text { cial militias, and soon also by the } \\
\text { General of the Imperial forces Jos } \\
\text { Echverri who finds common cause } \\
\text { with Santa Anna. Iturbide de- } \\
\text { cides to reconvene Congress and } \\
\text { abdicates in February } 1823 \text {. }\end{array}$ & 0 & 0 & Coup by military & $\begin{array}{l}\text { Meyer and } \\
\text { Sherman (1995: } \\
\text { 306-307); Archer } \\
(2000: 316)\end{array}$ \\
\hline Mexico & 3 & $\begin{array}{l}\text { Bravo- } \\
\text { Victoria- } \\
\text { Negrete } \\
\text { Provisional } \\
\text { Junta }\end{array}$ & $15 / 02 / 1823$ & 1 & $27 / 11 / 1823$ & $\begin{array}{l}\text { The Consituent Assembly meet } 27 \\
\text { November to draft a new constitu- } \\
\text { tion. }\end{array}$ & 10 & 10 & $\begin{array}{l}\text { Considered intended } \\
\text { transformational } \\
\text { process in which the } \\
\text { Provisional Junta } \\
\text { hands over power } \\
\text { the Constituent } \\
\text { Assembly. }\end{array}$ & $\begin{array}{l}\text { Meyer and } \\
\text { Sherman (1995: } \\
\text { 313-314); Archer } \\
(2000: 316-317)\end{array}$ \\
\hline
\end{tabular}




\begin{tabular}{|c|c|c|c|c|c|c|c|c|c|c|}
\hline $\begin{array}{l}\text { Country } \\
\text { name }\end{array}$ & $\begin{array}{l}\text { V-Dem } \\
\text { code }\end{array}$ & $\begin{array}{l}\text { Regime } \\
\text { name }\end{array}$ & v3regstartdate & & v3regenddate & Notes to v3regenddate & $\begin{array}{l}\text { v3regend- } \\
\text { typeMS }\end{array}$ & $\begin{array}{l}\text { v3regend- } \\
\text { type }\end{array}$ & Notes to v3regendtype & Sources \\
\hline Mexico & 3 & $\begin{array}{l}\text { The Second } \\
\text { Constituent } \\
\text { Assembly }\end{array}$ & $27 / 11 / 1823$ & 0 & $04 / 10 / 1824$ & $\begin{array}{l}\text { A moderate proposal of shared } \\
\text { sovereignty wins approval and the } \\
\text { constitution is ratified } 4 \text { October. }\end{array}$ & 10 & 10 & $\begin{array}{l}\text { An intended trans- } \\
\text { formational process } \\
\text { in which the Con- } \\
\text { stituent Congress } \\
\text { adopt a constitution } \\
\text { that is effectively } \\
\text { a compromise on } \\
\text { the distribution of } \\
\text { sovereignty. }\end{array}$ & $\begin{array}{l}\text { Archer (2000: } \\
316-317) ; \text { Meyer } \\
\text { and Sherman } \\
(1995: 314-320)\end{array}$ \\
\hline Mexico & 3 & $\begin{array}{l}\text { United } \\
\text { Mexican } \\
\text { States/Const } \\
\text { of } 1824\end{array}$ & $\begin{array}{l}04 / 10 / 1824 \\
\text { ution }\end{array}$ & 0 & $01 / 04 / 1829$ & $\begin{array}{l}\text { General Vicente Guerrero. Pe- } \\
\text { draza wins more states than } \\
\text { Guerrero in elections, whereupon } \\
\text { Santa Anna declares himself in } \\
\text { revolt. President Victoria fails } \\
\text { to suppress the revolt, and when } \\
\text { Guerrero joins, Pedraza gives up. }\end{array}$ & 1 & 1 & 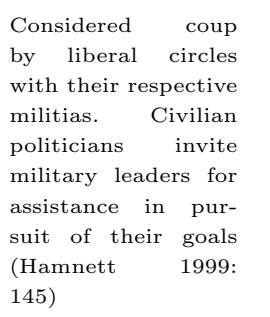 & $\begin{array}{l}\text { Meyer and } \\
\text { Sherman (1995: } \\
\text { 318-320); Archer } \\
\text { (2000: 326-327); } \\
\text { Hamnett (1999: } \\
\text { 145) }\end{array}$ \\
\hline Mexico & 3 & $\begin{array}{l}\text { Presidency } \\
\text { of Vincente } \\
\text { Guerrero }\end{array}$ & $01 / 04 / 1829$ & 0 & $17 / 12 / 1829$ & $\begin{array}{l}\text { In August Santa Anna confronts } \\
\text { the anticipated Spanish invasion } \\
\text { of reconquest and defeats the } \\
\text { Spanish. Few in Mexico can ri- } \\
\text { val his popularity. Guerrero him- } \\
\text { self fails to restore stability in } \\
\text { the country. Federalist-centralist } \\
\text { struggle continues and when a re- } \\
\text { volt breaks out against Guerrero, } \\
\text { the vice-president and many oth- } \\
\text { ers follow, but Santa Anna fights } \\
\text { on the president's side. Bus- } \\
\text { tanmante succeeds to overthrow } \\
\text { Guerrero, largely because of his } \\
\text { influence with the army. }\end{array}$ & 5,1 & 1 & $\begin{array}{l}\text { Considered a coup } \\
\text { by centralist and } \\
\text { conservatives under } \\
\text { the vice-presidents } \\
\text { leadership. Could } \\
\text { also be considered } \\
\text { loss in civil war, } \\
\text { based on the scale } \\
\text { of the revolt. }\end{array}$ & $\begin{array}{l}\text { Meyer and } \\
\text { Sherman (1995: } \\
\text { 320-321); Archer } \\
(2000: 326-327)\end{array}$ \\
\hline
\end{tabular}




\begin{tabular}{|c|c|c|c|c|c|c|c|c|c|c|}
\hline $\begin{array}{l}\text { Country } \\
\text { name }\end{array}$ & $\begin{array}{l}\text { V-Dem } \\
\text { code }\end{array}$ & $\begin{array}{l}\text { Regime } \\
\text { name }\end{array}$ & v3regstartdate & & v3regenddate & Notes to v3regenddate & $\begin{array}{l}\text { v3regend- } \\
\text { typeMS }\end{array}$ & $\begin{array}{l}\text { v3regend- } \\
\text { type }\end{array}$ & Notes to v3regendtype & Sources \\
\hline Mexico & 3 & $\begin{array}{l}\text { Presidency } \\
\text { of Anastasio } \\
\text { Bustamante }\end{array}$ & $17 / 12 / 1829$ & 0 & $15 / 01 / 1833$ & $\begin{array}{l}\text { The repressive policies of Busta- } \\
\text { mante brings increasing opposi- } \\
\text { tion, especially from the states } \\
\text { and from federalists in the capital. } \\
\text { Once again Santa Anna prepares } \\
\text { his troops for combat and rebels. } \\
\text { Confronting many uprisings and } \\
\text { battling several state militias, } \\
\text { Bustamante's government is over- } \\
\text { whelmed and compelled to surren- } \\
\text { der. }\end{array}$ & 5,1 & 5 & $\begin{array}{l}\text { Santa Anna's forces } \\
\text { manages to over- } \\
\text { throw Bustamante. } \\
\text { Could be considered } \\
\text { loss in civil war } \\
\text { because of the scale } \\
\text { of the uprising. } \\
\text { Santa Anna wins } \\
\text { but by a peace set- } \\
\text { tlement - the Plan } \\
\text { de Zavaleta. }\end{array}$ & $\begin{array}{l}\text { Meyer and } \\
\text { Sherman (1995: } \\
\text { 321-322); Archer } \\
(2000: 327-328)\end{array}$ \\
\hline Mexico & 3 & $\begin{array}{l}\text { Plan de } \\
\text { Zavaleta/ } \\
\text { Interim } \\
\text { Presidency } \\
\text { of Manuel } \\
\text { Gomez } \\
\text { Pedraza }\end{array}$ & $15 / 01 / 1833$ & 1 & $01 / 04 / 1833$ & $\begin{array}{l}\text { In March the state legislatures } \\
\text { cast their votes. Santa Anne wins } \\
\text { the largest majority in Mexican } \\
\text { history. Valentin Gmez Farias is } \\
\text { chosen as vice-president. }\end{array}$ & 10 & 10 & $\begin{array}{l}\text { Intended transfor- } \\
\text { mational process. } \\
\text { Peaceful handover } \\
\text { of power after } \\
\text { states cast their } \\
\text { presidential votes. }\end{array}$ & $\begin{array}{l}\text { Meyer and } \\
\text { Sherman (1995: } \\
\text { 324-326); Archer } \\
(2000 \text { : 328-330); } \\
\text { Bazant (1977: } \\
\text { 47) }\end{array}$ \\
\hline Mexico & 3 & $\begin{array}{l}\text { Presidency } \\
\text { of Antonio } \\
\text { Lpez de } \\
\text { Santa Anna }\end{array}$ & $01 / 04 / 1833$ & 0 & $27 / 01 / 1835$ & $\begin{array}{l}\text { The liberal program enrages the } \\
\text { clergy, the army and the conser- } \\
\text { vative elites and demand an end } \\
\text { to radical reform. Santa Anna } \\
\text { returns to Mexico City accepting } \\
\text { the argument that reforms have } \\
\text { gone way so far that it could lead } \\
\text { to civil war. He is convinced that } \\
\text { the Constitution of } 1824 \text { has made } \\
\text { Mexico ungovernable and changes } \\
\text { his sympathies in the wake of } \\
\text { Farias reforms. Santa Anna re- } \\
\text { moves Faris. }\end{array}$ & 2,1 & 1 & $\begin{array}{l}\text { Traditional elites, } \\
\text { the upper clergy } \\
\text { and powerful army } \\
\text { officers convince } \\
\text { Santa Anna to take } \\
\text { action to reestablish } \\
\text { the nation on cen- } \\
\text { tralist foundations. } \\
\text { In effect a shift in } \\
\text { the power balance } \\
\text { between federal- } \\
\text { ists and centralists } \\
\text { without a change } \\
\text { of leader. Could } \\
\text { be considered the } \\
\text { equivalent of a coup. } \\
\text { Or a combination of } \\
\text { coup and autogolpe. }\end{array}$ & $\begin{array}{l}\text { Meyer and } \\
\text { Sherman (1995: } \\
\text { 327-328); Archer } \\
(2000: 326-332)\end{array}$ \\
\hline
\end{tabular}




\begin{tabular}{|c|c|c|c|c|c|c|c|c|c|c|}
\hline $\begin{array}{l}\text { Country } \\
\text { name }\end{array}$ & $\begin{array}{l}\text { V-Dem } \\
\text { code }\end{array}$ & $\begin{array}{l}\text { Regime } \\
\text { name }\end{array}$ & v3regstartdate & & v3regenddate & Notes to v3regenddate & $\begin{array}{l}\text { v3regend- } \\
\text { typeMS }\end{array}$ & $\begin{array}{l}\text { v3regend- } \\
\text { type }\end{array}$ & Notes to v3regendtype & Sources \\
\hline Mexico & 3 & $\begin{array}{l}\text { Constitution } \\
\text { of Siete } \\
\text { Leyes/ } \\
\text { Centralist } \\
\text { regime of } \\
\text { Santa Anna }\end{array}$ & $27 / 01 / 1835$ & 0 & $16 / 07 / 1840$ & $\begin{array}{l}\text { The constitution reduces the au- } \\
\text { tonomous states with their legis- } \\
\text { latures to departments with gov- } \\
\text { ernors and councils appointed by } \\
\text { the central regime. The president } \\
\text { is to be elected indirectly to an } \\
\text { eight-year term. Suffrage is re- } \\
\text { stricted to men who earn a cer- } \\
\text { tain sum annually. The Texas cri- } \\
\text { sis and federalist uprisings, the } \\
\text { strongenst being in Yucatn which } \\
\text { desposes the governor, frustrate } \\
\text { centralist efforts to solidify their } \\
\text { system. By } 1840 \text { the centralist } \\
\text { regime does not possess enough } \\
\text { military power to control the sit- } \\
\text { uation. In the summer, violence } \\
\text { spills from the regions into Mexico } \\
\text { City when federalists led by Farias } \\
\text { and General Jos Urrea temporar- } \\
\text { ily arrests the then president Bus- } \\
\text { tamante. }\end{array}$ & 5,1 & 1 & Coup by otehr & $\begin{array}{l}\text { Archer } \\
(2000: 332-335)\end{array}$ \\
\hline Mexico & 3 & $\begin{array}{l}\text { Interregnum } \\
\text { Mexico } 1\end{array}$ & $16 / 07 / 1840$ & 0 & $22 / 09 / 1841$ & $\begin{array}{l}\text { Desparate for a solution, conser- } \\
\text { vatives conclude that the only an- } \\
\text { swer to the chaos is to restore } \\
\text { Santa Anna as interim president } \\
\text { and impose strong centralism and } \\
\text { dictatorial control. }\end{array}$ & 12 & 12 & $\begin{array}{l}\text { Santa Anna's army } \\
\text { manages to crush } \\
\text { the rebellion and } \\
\text { restore some order. } \\
\text { Regime does not } \\
\text { collapse, but the } \\
\text { situation comes so } \\
\text { out of hand that the } \\
\text { rebels manage to } \\
\text { hold the president } \\
\text { hostage for several } \\
\text { days. }\end{array}$ & $\begin{array}{l}\text { Archer (2000: } \\
334-335)\end{array}$ \\
\hline
\end{tabular}




\begin{tabular}{|c|c|c|c|c|c|c|c|c|c|c|}
\hline $\begin{array}{l}\text { Country } \\
\text { name }\end{array}$ & $\begin{array}{l}\text { V-Dem } \\
\text { code }\end{array}$ & $\begin{array}{l}\text { Regime } \\
\text { name }\end{array}$ & v3regstartdate & & v3regenddate & Notes to v3regenddate & $\begin{array}{l}\text { v3regend- } \\
\text { typeMS }\end{array}$ & $\begin{array}{l}\text { v3regend- } \\
\text { type }\end{array}$ & Notes to v3regendtype & Sources \\
\hline Mexico & 3 & $\begin{array}{l}\text { Constitution } \\
\text { of Siete } \\
\text { Leyes/Bases } \\
\text { Orgni- } \\
\text { cas/Centralist } \\
\text { regime of } \\
\text { Santa Anna }\end{array}$ & $22 / 09 / 1841$ & 0 & $06 / 12 / 1844$ & $\begin{array}{l}\text { The Bases further strenghtens the } \\
\text { presidency and stricter income } \\
\text { qualifications for voting ensure } \\
\text { that the centralist-conservative } \\
\text { regime still domintate the polit- } \\
\text { ical scene. By } 1844 \text {, news that } \\
\text { the United States plans to admit } \\
\text { Texas into the union, leads to ef- } \\
\text { forts to raise forces through con- } \\
\text { scription and to levy taxes on a } \\
\text { heavily indepted nation. At this } \\
\text { point Santa Anna lacks sufficient } \\
\text { support to protect his presidency. } \\
\text { In December, General Jos Herrera } \\
\text { leads a coup which ousts Santa } \\
\text { Anna. He is jailed in Jalapa. }\end{array}$ & 0 & 0 & $\begin{array}{l}\text { Considered a mili- } \\
\text { tary revolt led by } \\
\text { General Herrera. }\end{array}$ & $\begin{array}{l}\text { Archer (2000: } \\
335) ; \text { Hamnett } \\
(1999: 147)\end{array}$ \\
\hline Mexico & 3 & $\begin{array}{l}\text { Presidency } \\
\text { of Jos Her- } \\
\text { rera }\end{array}$ & $06 / 12 / 1844$ & 0 & $02 / 01 / 1846$ & $\begin{array}{l}\text { Joined by the Mexico City garri- } \\
\text { son under General Gabriel Valen- } \\
\text { cia, Paredes marches into the cap- } \\
\text { ital } 2 \text { January. Two days later } \\
\text { a new Council of Representatives } \\
\text { elect him president. }\end{array}$ & 0 & 0 & $\begin{array}{l}\text { Considered a mili- } \\
\text { tary revolt led by } \\
\text { generals Mariano } \\
\text { Paredes and Gabriel } \\
\text { Valencia. }\end{array}$ & $\begin{array}{l}\text { Vzquez (2000: } \\
356-359)\end{array}$ \\
\hline Mexico & 3 & $\begin{array}{l}\text { Presidency } \\
\text { of Mariano } \\
\text { Paredes }\end{array}$ & $02 / 01 / 1846$ & 0 & $04 / 08 / 1846$ & $\begin{array}{l}\text { On the brink of war, Paredes fail- } \\
\text { ure to defend Mexico against U.S. } \\
\text { hostility together with his monar- } \\
\text { chy project, makes him highly un- } \\
\text { popular. He is left without sup- } \\
\text { porters. Army garrisons rebel in } \\
\text { support of the } 1824 \text { constitution } \\
\text { and the return of Santa Anna. }\end{array}$ & 0 & 0 & $\begin{array}{l}\text { General Mariano } \\
\text { Salas revolts in } \\
\text { Mexico City with } \\
\text { the support of } \\
\text { Farias. }\end{array}$ & $\begin{array}{l}\text { Vzquez (2000: } \\
\text { 360-362); Bazant } \\
(1977: 55-57)\end{array}$ \\
\hline Mexico & 3 & $\begin{array}{l}\text { Interim } \\
\text { Government } \\
\text { under Mar- } \\
\text { iano Salas } \\
\text { and Valentin } \\
\text { Gomez } \\
\text { Farias }\end{array}$ & $04 / 08 / 1846$ & 0 & $22 / 08 / 1846$ & $\begin{array}{l}\text { The Constitution of } 1824 \text { is re- } \\
\text { stored. }\end{array}$ & 10 & 10 & $\begin{array}{l}\text { Considered intended } \\
\text { transformational } \\
\text { process favoured by } \\
\text { federalists in power. }\end{array}$ & $\begin{array}{l}\text { Hamnett (1999: } \\
\text { 154); Bazant } \\
\text { (1977: 56-57); } \\
\text { Vzquez (2000: } \\
\text { 361) }\end{array}$ \\
\hline
\end{tabular}




\begin{tabular}{|c|c|c|c|c|c|c|c|c|c|c|}
\hline $\begin{array}{l}\text { Country } \\
\text { name }\end{array}$ & $\begin{array}{l}\text { V-Dem } \\
\text { code }\end{array}$ & $\begin{array}{l}\text { Regime } \\
\text { name }\end{array}$ & v3regstartdate & & v3regenddate & Notes to v3regenddate & $\begin{array}{l}\text { v3regend- } \\
\text { typeMS }\end{array}$ & $\begin{array}{l}\text { v3regend- } \\
\text { type }\end{array}$ & Notes to v3regendtype & Sources \\
\hline Mexico & 3 & $\begin{array}{l}\text { Constitution } \\
\text { of } 1824 / \text { Gov- } \\
\text { ernments of } \\
\text { Santa Anna, } \\
\text { Farias, Salas, } \\
\text { Anaya }\end{array}$ & $22 / 08 / 1846$ & 0 & $15 / 09 / 1847$ & $\begin{array}{l}\text { The Mexican War ends in vic- } \\
\text { tory for the United States. On } \\
\text { the evening of } 15 \text { September, af- } \\
\text { ter days of heavy battles in and } \\
\text { around Mexico City, their flag } \\
\text { flutters over the national palace, } \\
\text { and Santa Anna resignes the pres- } \\
\text { idency. }\end{array}$ & 6,7 & 6 & $\begin{array}{l}\text { Loss in interstate } \\
\text { war }\end{array}$ & $\begin{array}{l}\text { Vzquez (2000: } \\
362-367) ; \text { Bazant } \\
(1977: 56-57) ; \\
\text { Meyer and } \\
\text { Sherman (1995: } \\
\text { 350-351) }\end{array}$ \\
\hline Mexico & 3 & $\begin{array}{l}\text { United } \\
\text { States } \\
\text { occupation }\end{array}$ & $15 / 09 / 1847$ & 0 & $30 / 05 / 1848$ & $\begin{array}{l}\text { On } 30 \text { May Mexico and the United } \\
\text { States exchange ratified copies of } \\
\text { the treaty. Presidential elections } \\
\text { favor Jos Herrera, who by the } \\
\text { middle of June re-instates the } \\
\text { government in Mexico City when } \\
\text { U.S. forces leave. }\end{array}$ & 10 & 10 & $\begin{array}{l}\text { Both the Mexi- } \\
\text { can and the U.S. } \\
\text { Congress ratify the } \\
\text { treaty of Guadalupe } \\
\text { Hidalgo ending } \\
\text { the occupation. } \\
\text { Intended transfor- } \\
\text { mational process by } \\
\text { the U.S. occupying } \\
\text { power? }\end{array}$ & $\begin{array}{l}\text { Meyer and } \\
\text { Sherman (1995: } \\
351) \text {; Vzquez } \\
(2000: 366-369)\end{array}$ \\
\hline Mexico & 3 & $\begin{array}{l}\text { Constitution } \\
\text { of } 1824 / \text { Gov- } \\
\text { ernments of } \\
\text { Jos Herrera, } \\
\text { Mariano } \\
\text { Arista }\end{array}$ & $30 / 05 / 1848$ & 0 & $20 / 04 / 1853$ & $\begin{array}{l}\text { In the aftermath of the Mexican } \\
\text { War, Congress consists of two po- } \\
\text { litical factions, the liberals and } \\
\text { the conservatives. The Liberals } \\
\text { stay in power until } 1853 \text {. The } \\
\text { years from } 1848 \text { until } 1853 \text { are } \\
\text { marked by a fragile peacefullness } \\
\text { where the parties' points of view } \\
\text { are debated in public forum. But } \\
\text { renewed strife is catalyzed by a } \\
\text { military coup led by conservatives } \\
\text { installing Santa Anna back in the } \\
\text { executive. }\end{array}$ & 1,0 & 1 & $\begin{array}{l}\text { Considered a coup } \\
\text { by the conservatives } \\
\text { and their junta sup- } \\
\text { porters inviting back } \\
\text { Santa Anna as pres- } \\
\text { ident. }\end{array}$ & $\begin{array}{l}\text { Bazant (1977: } \\
60)\end{array}$ \\
\hline Mexico & 3 & $\begin{array}{l}\text { Rule of } \\
\text { Antonio } \\
\text { Lopez de } \\
\text { Santa Anna }\end{array}$ & $20 / 04 / 1853$ & 0 & $09 / 08 / 1855$ & $\begin{array}{l}\text { The Gadsden purchase, where } \\
\text { Santa Anna sells of the last bit of } \\
\text { land needed to round off the U.S. } \\
\text { territorial acquisition of } 1848 \text {, is } \\
\text { a step too far for Juan Alvarez } \\
\text { who launches a liberal popular re- } \\
\text { volt endorsed by many segments } \\
\text { of society, including the peasants. } \\
\text { In August Santa Anna tenders his } \\
\text { resignation and goes into exile. }\end{array}$ & $0,1,8$ & 8 & $\begin{array}{l}\text { The revolution of } \\
\text { Ayutla enjoys a } \\
\text { wider base of sup- } \\
\text { port than most } \\
\text { previous antigovern- } \\
\text { ment movements. } \\
\text { Many rebellions take } \\
\text { place around the } \\
\text { conutry. Could be } \\
\text { considered popular } \\
\text { uprising. }\end{array}$ & $\begin{array}{l}\text { Vanderwood } \\
(2010: 371- \\
\text { 373); Meyer and } \\
\text { Sherman 1995: } \\
\text { 373-376); Bazant } \\
(1977: 61)\end{array}$ \\
\hline
\end{tabular}




\begin{tabular}{|c|c|c|c|c|c|c|c|c|c|c|}
\hline $\begin{array}{l}\text { Country } \\
\text { name }\end{array}$ & $\begin{array}{l}\text { V-Dem } \\
\text { code }\end{array}$ & $\begin{array}{l}\text { Regime } \\
\text { name }\end{array}$ & v3regstartdate & & v3regenddate & Notes to v3regenddate & $\begin{array}{l}\text { v3regend- } \\
\text { typeMS }\end{array}$ & $\begin{array}{l}\text { v3regend- } \\
\text { type }\end{array}$ & Notes to v3regendtype & Sources \\
\hline Mexico & 3 & $\begin{array}{l}\text { Liberal } \\
\text { interim } \\
\text { governments } \\
\text { of Jun lvarez } \\
\text { and Ignacio } \\
\text { Comonfort }\end{array}$ & $09 / 08 / 1855$ & 0 & $05 / 02 / 1857$ & $\begin{array}{l}\text { The new constitution is promul- } \\
\text { gated in February } 1857 \text {. The con- } \\
\text { stitution provides for the aboli- } \\
\text { tion of clerical and military im- } \\
\text { munities, basic human rights, pro- } \\
\text { tected private property, equality } \\
\text { beofre the law, freedom of speech, } \\
\text { and the preservation of federalist } \\
\text { system with its power in unicam- } \\
\text { eral national legislature. }\end{array}$ & 9 & 9 & $\begin{array}{l}\text { Considered substan- } \\
\text { tial political liberal- } \\
\text { ization. }\end{array}$ & $\begin{array}{l}\text { Meyer and } \\
\text { Sherman (1995: } \\
\text { 379-380); Bazant } \\
(1977: 72-73)\end{array}$ \\
\hline Mexico & 3 & $\begin{array}{l}\text { The Con- } \\
\text { stitution of } \\
1857\end{array}$ & $05 / 02 / 1857$ & 0 & $15 / 12 / 1857$ & $\begin{array}{l}\text { The liberals soon find the imple- } \\
\text { mentation of the constitution go- } \\
\text { ing very slow. In December, the } \\
\text { sitting president Comonfort allies } \\
\text { himself with a conservative gen- } \\
\text { eral, Flix Zuloaga, in a military } \\
\text { coup. }\end{array}$ & 0,2 & 2 & $\begin{array}{l}\text { A self-coup accom- } \\
\text { panied by the mili- } \\
\text { tary. }\end{array}$ & $\begin{array}{l}\text { Vanderwood } \\
(2010)\end{array}$ \\
\hline Mexico & 3 & $\begin{array}{l}\text { Comonfort } \\
\text { presidency }\end{array}$ & $15 / 12 / 1857$ & 1 & $11 / 01 / 1858$ & $\begin{array}{l}\text { Within a month Comonfort be- } \\
\text { comes disenchanted with his new } \\
\text { conservative partners. General } \\
\text { Zuloaga decides, with clerical and } \\
\text { military support, to oust Comon- } \\
\text { fort and assume the presidency for } \\
\text { himself. Meanwhile, the liberals } \\
\text { rally under Benito Jurez, Supreme } \\
\text { Court leader and constitutionally } \\
\text { next in line for the presidency. }\end{array}$ & 0 & 0 & $\begin{array}{l}\text { A military leader, } \\
\text { Zuloaga seeks to } \\
\text { defend the country } \\
\text { against "the anar- } \\
\text { chy he sees being } \\
\text { unleashed by liberal- } \\
\text { ism" and overthrows } \\
\text { Comonfort. }\end{array}$ & $\begin{array}{l}\text { Vanderwood } \\
(2010) ; \text { Meyer } \\
\text { and Sherman } \\
(1995: 381-282)\end{array}$ \\
\hline Mexico & 3 & $\begin{array}{l}\text { Conservative } \\
\text { regime under } \\
\text { Flix Zuloaga } \\
\text { and Miguel } \\
\text { Miramn }\end{array}$ & $11 / 01 / 1858$ & 0 & $01 / 01 / 1861$ & $\begin{array}{l}\text { The liberals eventually succeed in } \\
\text { establishing a capital in Veracruz. } \\
\text { For the first two years they are } \\
\text { barely able to hold their guard } \\
\text { against a well-equipped conserva- } \\
\text { tive army. By } 1860 \text { the tide turns, } \\
\text { and on New Year's Day, Jurez and } \\
\text { the liberals enter Mexico City. }\end{array}$ & 5 & 5 & $\begin{array}{l}\text { Conservatives loose } \\
\text { in civil war. }\end{array}$ & $\begin{array}{l}\text { Meyer and Sher- } \\
\text { man (1995: } \\
\text { 381-384); Van- } \\
\text { derwood (2010) }\end{array}$ \\
\hline Mexico & 3 & $\begin{array}{l}\text { Constitution } \\
\text { of } 1857 / \text { Gov- } \\
\text { ernment of } \\
\text { Benito Jurez }\end{array}$ & $01 / 01 / 1861$ & 0 & $10 / 07 / 1863$ & $\begin{array}{l}\text { It takes two efforts before the } \\
\text { French siege Mexico City in June } \\
\text { 1863. On May } 31 \text {, Jurez evacuates } \\
\text { with his army for San Luis Potosi. }\end{array}$ & 7 & 7 & $\begin{array}{l}\text { Considered foreign } \\
\text { intervention } \\
\text { French troops. }\end{array}$ & $\begin{array}{l}\text { Meyer and Sher- } \\
\text { man (1995: } \\
\text { 388-391); Van- } \\
\text { derwood (2010); } \\
\text { Hamnett (1999: } \\
\text { 167-168) }\end{array}$ \\
\hline
\end{tabular}




\begin{tabular}{|c|c|c|c|c|c|c|c|c|c|c|}
\hline $\begin{array}{l}\text { Country } \\
\text { name }\end{array}$ & $\begin{array}{l}\text { V-Dem } \\
\text { code }\end{array}$ & $\begin{array}{l}\text { Regime } \\
\text { name }\end{array}$ & v3regstartdate & & v3regenddate & Notes to v3regenddate & $\begin{array}{l}\text { v3regend- } \\
\text { typeMS }\end{array}$ & $\begin{array}{l}\text { v3regend- } \\
\text { type }\end{array}$ & Notes to v3regendtype & Sources \\
\hline Mexico & 3 & $\begin{array}{l}\text { French } \\
\text { occupation/ } \\
\text { Assembly of } \\
\text { Notables/ } \\
\text { Regency } \\
\text { of Juan } \\
\text { Almonte, } \\
\text { Jos Mariano } \\
\text { Salas and } \\
\text { Pelagio } \\
\text { Labastida }\end{array}$ & $10 / 07 / 1863$ & 0 & $10 / 06 / 1864$ & $\begin{array}{l}\text { The French secure central Mex- } \\
\text { ico. In October a delegation of } \\
\text { Mexican conservatives visits Max- } \\
\text { imilian, Napoleon's choice for the } \\
\text { throne, and offer him the crown } \\
\text { on behalf of the Assembly. On } 10 \\
\text { June Maximilian arrives in Mex- } \\
\text { ico. }\end{array}$ & 10 & 10 & $\begin{array}{l}\text { Intended transfor- } \\
\text { mational process by } \\
\text { the sitting regime. } \\
\text { Napoleon III signs } \\
\text { the Convention of } \\
\text { Miramar agreeing } \\
\text { on the relationship } \\
\text { between Napoleon } \\
\text { and Maximilian. }\end{array}$ & $\begin{array}{l}\text { Meyer and Sher- } \\
\text { man (1995: } \\
\text { 391-393); Van- } \\
\text { derwood (2010) }\end{array}$ \\
\hline Mexico & 3 & $\begin{array}{l}\text { French } \\
\text { occupation/ } \\
\text { Rule of } \\
\text { Emperor } \\
\text { Maximilian I }\end{array}$ & $10 / 06 / 1864$ & 0 & $15 / 07 / 1867$ & $\begin{array}{l}\text { Several factors, including threats } \\
\text { from the United States who } \\
\text { openly support Jurez, lead to the } \\
\text { withdrawal of French troops in } \\
1866 \text { and } 1867 \text {. The liberal Juar- } \\
\text { istas under Generals Mariano Es- } \\
\text { cobedo and Porfirio Diaz begin } \\
\text { to put pressure on the Emperor. } \\
\text { Maximilian surrenders after being } \\
\text { surrounded by the liberal army on } \\
15 \text { May. }\end{array}$ & 8 & 8 & $\begin{array}{l}\text { Considered a re- } \\
\text { publican uprising } \\
\text { against an unpopu- } \\
\text { lar foreign emperor. }\end{array}$ & $\begin{array}{l}\text { Meyer and Sher- } \\
\text { man (1995: } \\
\text { 397-399); Van- } \\
\text { derwood (2010) }\end{array}$ \\
\hline Mexico & 3 & $\begin{array}{l}\text { Constitution } \\
\text { of } 1857 / \\
\text { Government } \\
\text { of Benito } \\
\text { Jurez/ } \\
\text { Government } \\
\text { of Lerdo de } \\
\text { Tejada }\end{array}$ & $15 / 07 / 1867$ & 0 & $21 / 11 / 1876$ & $\begin{array}{l}\text { Congress re-elects Jurez for a } \\
\text { fourth term. But the Constitution } \\
\text { is not put aside for other reasons } \\
\text { than this. Diaz does not accept } \\
\text { the decision and revolts, but the } \\
\text { matter is settled when Jurez dies } \\
\text { of illness. It seems that Diaz re- } \\
\text { volts entirely on the principle of } \\
\text { re-election. He accepts the fol- } \\
\text { lowing defeat in the elections after } \\
\text { Jurez death. The winner Lerdo de } \\
\text { Tejada follows the same policies } \\
\text { formulated by Jurez. In March } \\
1876 \text {, Diaz launches his Revolu- } \\
\text { tion of Tuxtepec tired of presi- } \\
\text { dents seeking re-election. He cap- } \\
\text { tures Mexico City } 21 \text { November } \\
1876 \text {. }\end{array}$ & 1 & 1 & $\begin{array}{l}\text { Hamnett }(1999) \\
\text { leaves it an open } \\
\text { question whether } \\
\text { the period of the } \\
\text { Restored Repub- } \\
\text { lic (1867-1876) is } \\
\text { marked by a con- } \\
\text { stitutionalism or } \\
\text { personal rule. A } \\
\text { coup d'état, with } \\
\text { soldiers in a number } \\
\text { of states flocking } \\
\text { to Diaz "effective } \\
\text { suffrage" banner } \\
\text { raises Porfirio Diaz } \\
\text { to the presidency. }\end{array}$ & $\begin{array}{l}\text { Vanderwood } \\
(2010) \text {; Meyer } \\
\text { and Sherman } \\
(1995: \text { 409-414); } \\
\text { Hamnett (1999: } \\
180,196)\end{array}$ \\
\hline
\end{tabular}




\begin{tabular}{|c|c|c|c|c|c|c|c|c|c|c|}
\hline $\begin{array}{l}\text { Country } \\
\text { name }\end{array}$ & $\begin{array}{l}\text { V-Dem } \\
\text { code }\end{array}$ & $\begin{array}{l}\text { Regime } \\
\text { name }\end{array}$ & v3regstartdate & & v3regenddate & Notes to v3regenddate & $\begin{array}{l}\text { v3regend- } \\
\text { typeMS }\end{array}$ & $\begin{array}{l}\text { v3regend- } \\
\text { type }\end{array}$ & Notes to v3regendtype & Sources \\
\hline Mexico & 3 & $\begin{array}{l}\text { Constitution } \\
\text { of } 1857 / \\
\text { Governments } \\
\text { of Porfirio } \\
\text { Diaz and } \\
\text { Manuel } \\
\text { Gonzlez }\end{array}$ & $21 / 11 / 1876$ & 0 & $01 / 12 / 1884$ & $\begin{array}{l}\text { Gonzlez is elected with a large } \\
\text { majority, maibly due to Diaz' } \\
\text { popularity. Diaz hands over } \\
\text { power peacefully knowing that he } \\
\text { could serve again after the inter- } \\
\text { vening term of Gonzlez. Some ar- } \\
\text { gue that Diaz throws his support } \\
\text { behind Gonzlez beacuse he does } \\
\text { not trust other candidates hand- } \\
\text { ing back power to him if he wins } \\
\text { the } 1884 \text { elections (Hamnett 1999: } \\
\text { 197). Others reject the portrayal } \\
\text { of Gonzlez as a puppet of Diaz } \\
\text { and argue that Diaz dictatorial } \\
\text { aspirations begins with his sec- } \\
\text { ond term. (Meyer and Sherman } \\
\text { 1995: } 436-437 \text {; Coerver } 1979 \text { ). It } \\
\text { seems that Diaz plays the politi- } \\
\text { cal game well, using his four years } \\
\text { out of office to build a new polit- } \\
\text { ical machine to win the upcoming } \\
\text { elections. In September } 1884 \text { he } \\
\text { sweeps back to victory. }\end{array}$ & 2,10 & 2 & $\begin{array}{l}\text { Totally contrary } \\
\text { to his principles, } \\
\text { Diaz makes sure } \\
\text { that he is able to } \\
\text { run for president } \\
\text { indefinetely. Diaz } \\
\text { effectively initiates } \\
\text { an autogolpe. He } \\
\text { convinces both } \\
\text { congress and his } \\
\text { personal clients } \\
\text { that sotrng man } \\
\text { rule is necessary for } \\
\text { political stability } \\
\text { and economic devel- } \\
\text { opment. His inner } \\
\text { circle supervise } \\
\text { official newspapers } \\
\text { and marginalizes } \\
\text { opposition. A fur- } \\
\text { ther amendment } \\
\text { to the constitution } \\
\text { removes the spec- } \\
\text { ification for one } \\
\text { reelection making } \\
\text { it possible to run } \\
\text { indefinetely. }\end{array}$ & $\begin{array}{l}\text { Meyer and Sher- } \\
\text { man 1995: 436- } \\
\text { 438); Hamnett } \\
\text { (1999: 196-200, } \\
\text { 204) }\end{array}$ \\
\hline Mexico & 3 & $\begin{array}{l}\text { Regime of } \\
\text { Porfirio Diaz }\end{array}$ & $01 / 12 / 1884$ & 0 & $25 / 05 / 1911$ & $\begin{array}{l}\text { Madero's victory over federal } \\
\text { troops in Ciudad Jurez in April } \\
\text { and the eruption of rebellion } \\
\text { across the country, leads Diaz to } \\
\text { sign a peace treaty and hand over } \\
\text { power to Madero. Diaz signs his } \\
\text { resignations } 25 \text { May. }\end{array}$ & 8 & 8 & $\begin{array}{lr}\text { Considered } & \text { popular } \\
\text { uprising against } & \text { agaly } \\
\text { the increasingly } \\
\text { suppressive Diaz } \\
\text { regime. }\end{array}$ & $\begin{array}{l}\text { Meyer and } \\
\text { Sherman }(1995: \\
438,502-505) ; \\
\text { Hart }(2002: \\
438-439)\end{array}$ \\
\hline Mexico & 3 & $\begin{array}{l}\text { Interim } \\
\text { Government } \\
\text { of Lon de la } \\
\text { Barra }\end{array}$ & $25 / 05 / 1911$ & 0 & $05 / 11 / 1911$ & $\begin{array}{l}\text { Franscisco Madero is opposed } \\
\text { only by minor candidates and } \\
\text { wins the elections. He is installed } \\
5 \text { November. }\end{array}$ & 10 & 10 & $\begin{array}{l}\text { Conisdered intended } \\
\text { transformational } \\
\text { process in which an } \\
\text { interim government } \\
\text { hands over power } \\
\text { to an elected one. } \\
\text { Elections are not } \\
\text { based on extensive } \\
\text { suffrage. }\end{array}$ & $\begin{array}{l}\text { Hart (2002: } \\
\text { 439); Meyer and } \\
\text { Sherman (1995: } \\
506-509)\end{array}$ \\
\hline
\end{tabular}




\begin{tabular}{|c|c|c|c|c|c|c|c|c|c|c|}
\hline $\begin{array}{l}\text { Country } \\
\text { name }\end{array}$ & $\begin{array}{l}\text { V-Dem } \\
\text { code }\end{array}$ & $\begin{array}{l}\text { Regime } \\
\text { name }\end{array}$ & v3regstartdate & & v3regenddate & Notes to v3regenddate & $\begin{array}{l}\text { v3regend- } \\
\text { typeMS }\end{array}$ & $\begin{array}{l}\text { v3regend- } \\
\text { type }\end{array}$ & Notes to v3regendtype & Sources \\
\hline Mexico & 3 & $\begin{array}{l}\text { Government } \\
\text { of Francisco } \\
\text { Madero }\end{array}$ & $05 / 11 / 1911$ & 0 & $18 / 02 / 1913$ & $\begin{array}{l}\text { A military coup begins in Mexico } \\
\text { City in February 1913. General } \\
\text { Manuel Mondragn, supported by } \\
\text { artillery regiments, release rebel } \\
\text { leaders Bernando Reyes and Flix } \\
\text { Diaz from prison and marches on } \\
\text { the National Palace. After ten } \\
\text { days of fighting in Mexico City, } \\
\text { "the Ten Tragic Days", govern- } \\
\text { ment forces under General Victo- } \\
\text { riano Huerta change sides and ar- } \\
\text { rest Madero and numerous gov- } \\
\text { ernment officers on } 18 \text { February. }\end{array}$ & 0 & 0 & $\begin{array}{l}\text { Considered a mili- } \\
\text { tary coup after gov- } \\
\text { ernment forces takes } \\
\text { side with the rebels } \\
\text { and order the arrest } \\
\text { of the sitting presi- } \\
\text { dent. }\end{array}$ & $\begin{array}{l}\text { Meyer and } \\
\text { Sherman (1995: } \\
517-521) \text {; Hart } \\
(2002: 444-445)\end{array}$ \\
\hline Mexico & 3 & $\begin{array}{l}\text { Government } \\
\text { of Victoriano } \\
\text { Huerta }\end{array}$ & $18 / 02 / 1913$ & 0 & $08 / 07 / 1914$ & $\begin{array}{l}\text { While Huerta decides to make a } \\
\text { show of force against the Ameri- } \\
\text { cans in the north, constitutional- } \\
\text { ists and zapatistas fill the military } \\
\text { vacuum in the center. Huerta's } \\
\text { position becomes unteable. He re- } \\
\text { signs } 8 \text { July } 1914 \text {. }\end{array}$ & 5 & 5 & $\begin{array}{l}\text { Considered regime } \\
\text { loss in civil war. }\end{array}$ & $\begin{array}{l}\text { Hart (2002: 449- } \\
451) \text {; Meyer and } \\
\text { Sherman (1995: } \\
531-534)\end{array}$ \\
\hline Mexico & 3 & $\begin{array}{l}\text { Interregnum } \\
\text { Mexico } 3\end{array}$ & 08/07/1914 & 0 & $01 / 03 / 1917$ & $\begin{array}{l}\text { In late } 1916 \text { Carranza feels secure } \\
\text { enough to convene a constituent } \\
\text { Congress for the purpose of draw- } \\
\text { ing up a new constitution. In spe- } \\
\text { cial elections in March, Carranza } \\
\text { wins and takes the oath of office } 1 \\
\text { May. }\end{array}$ & 5,12 & 5 & Loss in civil war & $\begin{array}{l}\text { Meyer and } \\
\text { Sherman (1995: } \\
535-539) ; \text { Hart } \\
(2002: 452-456) ; \\
\text { Hamnett (1999: } \\
\text { 219-221) }\end{array}$ \\
\hline Mexico & 3 & $\begin{array}{l}\text { Govern- } \\
\text { ment of } \\
\text { Venustiano } \\
\text { Carranza }\end{array}$ & $01 / 03 / 1917$ & 0 & $20 / 05 / 1920$ & $\begin{array}{l}\text { When Carranza bypasses his for- } \\
\text { mer general Obregn and at- } \\
\text { tempts to impose a pliant suc- } \\
\text { cessor in } 1920 \text {, Obregn is joined } \\
\text { by Plutarco Calles, Adolfo de la } \\
\text { Huerta and leading Zapatistas in } \\
\text { a march on Mexico City that } \\
\text { drives out Carranza. Carranza is } \\
\text { assassinated } 20 \text { May } 1920 \text {. }\end{array}$ & 1 & 1 & $\begin{array}{l}\text { An armed insurrec- } \\
\text { tion led by General } \\
\text { Obregn, Plutarco } \\
\text { Calles and Adolfo } \\
\text { de la Huerta. Not } \\
\text { clear how much pop- } \\
\text { ularity the uprising } \\
\text { enjoys. }\end{array}$ & $\begin{array}{l}\text { Hart (2002: } \\
\text { 461-465); Meyer } \\
\text { and Sherman } \\
\text { (1995: 545-550); } \\
\text { Hamnett (1999: } \\
\text { 221-223) }\end{array}$ \\
\hline Mexico & 3 & $\begin{array}{l}\text { Congres- } \\
\text { sional regime }\end{array}$ & $20 / 05 / 1920$ & 0 & $01 / 12 / 1928$ & President Obregon is assasinated & 3 & 3 & $\begin{array}{l}\text { President Obregon is } \\
\text { assasinated }\end{array}$ & \\
\hline
\end{tabular}




\begin{tabular}{|c|c|c|c|c|c|c|c|c|c|c|}
\hline $\begin{array}{l}\text { Country } \\
\text { name }\end{array}$ & $\begin{array}{l}\text { V-Dem } \\
\text { code }\end{array}$ & $\begin{array}{l}\text { Regime } \\
\text { name }\end{array}$ & v3regstartdate & & v3regenddate & Notes to v3regenddate & $\begin{array}{l}\text { v3regend- } \\
\text { typeMS }\end{array}$ & $\begin{array}{l}\text { v3regend- } \\
\text { type }\end{array}$ & Notes to v3regendtype & Sources \\
\hline Mexico & 3 & PRI Mexico & $01 / 12 / 1928$ & 0 & $02 / 07 / 2000$ & $\begin{array}{l}\text { On } 2 \text { July } 2000 \text { the PAN can- } \\
\text { didate Vicente Fox Quesada was } \\
\text { elected president, marking the } \\
\text { end of } 71 \text { years of PRI presiden- } \\
\text { tial rule. }\end{array}$ & 9 & 9 & $\begin{array}{l}\text { Coded directed lib- } \\
\text { eralization because } \\
\text { of the opening of } \\
\text { the electoral system } \\
\text { through legislation } \\
\text { by the PRI in } 1997\end{array}$ & $\begin{array}{l}\text { Schedler (2000), } \\
\text { Britannica }\end{array}$ \\
\hline Mexico & 3 & $\begin{array}{l}\text { Post-single } \\
\text { party Mexico }\end{array}$ & $02 / 07 / 2000$ & 0 & $\mathrm{E}$ & & & & & $\begin{array}{l}\text { Schedler (2000), } \\
\text { Britannica }\end{array}$ \\
\hline China & 110 & $\begin{array}{l}\text { Quing } \\
\text { Dynasty pre- } \\
\text { occupation }\end{array}$ & $27 / 12 / 1722$ & 0 & $13 / 10 / 1860$ & $\begin{array}{l}\text { In } 1858 \text {, the Second Opium War } \\
\text { or Arrow War with the French } \\
\text { and the British leads to a tempo- } \\
\text { rary interruption in their dynas- } \\
\text { tic rule. A combined invasion of } \\
\text { British and French forces leads to } \\
\text { an occupation of Beijing in } 1860 \text {. }\end{array}$ & 7 & 7 & $\begin{array}{lr}\text { Considered } & \text { foreign } \\
\text { intervention } & \text { by } \\
\text { British and } & \text { French } \\
\text { forces. } & \end{array}$ & $\begin{array}{l}\text { Roberts (1996: } \\
\text { 214-226); Dillon } \\
(2010: 65-99 \\
\text { 100-104) }\end{array}$ \\
\hline China & 110 & $\begin{array}{l}\text { British } \\
\text { and French } \\
\text { occupation } \\
\text { of Beijing }\end{array}$ & $13 / 10 / 1860$ & 0 & $25 / 10 / 1860$ & $\begin{array}{l}\text { The Convention of Beijing, un- } \\
\text { der which the Qing court guar- } \\
\text { anteed to respect the provisions } \\
\text { of the treaty is dictated to the } \\
\text { Prince and signed } 24 \text { and } 25 \text { Octo- } \\
\text { ber by the Prince and Britain and } \\
\text { France. }\end{array}$ & 12 & 10 & $\begin{array}{l}\text { The foreign powers } \\
\text { get what they came } \\
\text { for. The signing } \\
\text { of the Convention } \\
\text { of Beijing concludes } \\
\text { the conflict. It is } \\
\text { a humiliating defeat } \\
\text { to the Qing court. } \\
\text { The court is restored } \\
\text { to the capital. }\end{array}$ & $\begin{array}{l}\text { Dillon (2010: } \\
\text { 102-104); Britan- } \\
\text { nica }\end{array}$ \\
\hline China & 110 & $\begin{array}{l}\text { Qing Dy- } \\
\text { nasty/ } \\
\text { Reign of the } \\
\text { Xianfeng } \\
\text { Emperor }\end{array}$ & $25 / 10 / 1860$ & 0 & $11 / 11 / 1861$ & $\begin{array}{l}\text { Xianfeng is succeeded by Tongzhi } \\
\text { whos is only five years old. The } \\
\text { Qing court appoints eight regents } \\
\text { to rule during his minority. His } \\
\text { mother Cixi and Ci'an, the wife of } \\
\text { Xianfeng dissaproves of the choice } \\
\text { of regents, despose them in a } \\
\text { palace coup and take power, rul- } \\
\text { ing jointly as regents with Prince } \\
\text { Gong. Most of the regents are be- } \\
\text { headed. }\end{array}$ & 1 & 1 & $\begin{array}{l}\text { Considered a palace } \\
\text { coup. }\end{array}$ & $\begin{array}{l}\text { Dillon (2010: } \\
\text { 104-106); Britan- } \\
\text { nica }\end{array}$ \\
\hline
\end{tabular}




\begin{tabular}{|c|c|c|c|c|c|c|c|c|c|c|}
\hline $\begin{array}{l}\text { Country } \\
\text { name }\end{array}$ & $\begin{array}{l}\text { V-Dem } \\
\text { code }\end{array}$ & $\begin{array}{l}\text { Regime } \\
\text { name }\end{array}$ & v3regstartdate & & v3regenddate & Notes to v3regenddate & $\begin{array}{l}\text { v3regend- } \\
\text { typeMS }\end{array}$ & $\begin{array}{l}\text { v3regend- } \\
\text { type }\end{array}$ & Notes to v3regendtype & Sources \\
\hline China & 110 & $\begin{array}{l}\text { Qing Dy- } \\
\text { nasty/ } \\
\text { Regency of } \\
\text { Cixi, Ci'an } \\
\text { and Prince } \\
\text { Gong/ } \\
\text { Tongzhi } \\
\text { Regency }\end{array}$ & $11 / 11 / 1861$ & 0 & $25 / 02 / 1875$ & $\begin{array}{l}\text { When Tongzhi dies the two em- } \\
\text { presses og on to act as regents. } \\
\text { Their choice of Zaitian as suc- } \\
\text { cessor should according to the } \\
\text { laws of dynastic succesion have } \\
\text { been ineligible. However Empress } \\
\text { Cixi is influental enough to pre- } \\
\text { vail and Zaitian is crowned as } \\
\text { the Guangxu Emperor } 25 \text { Febru- } \\
\text { ary } 1875 \text {. }\end{array}$ & 2,10 & 2 & $\begin{array}{l}\text { Could be considered } \\
\text { a self-coup, but } \\
\text { there is not much } \\
\text { information on the } \\
\text { transition of power } \\
\text { from Tongzh to } \\
\text { Guangxu. }\end{array}$ & $\begin{array}{l}\text { Dillon (2010: } \\
\text { 105); Britannica }\end{array}$ \\
\hline China & 110 & $\begin{array}{l}\text { Qing Dy- } \\
\text { nasty/Regency } \\
\text { of Empress } \\
\text { Cixi/Reign } \\
\text { of the } \\
\text { Emperor } \\
\text { Guangxu }\end{array}$ & $25 / 02 / 1875$ & 0 & $21 / 09 / 1898$ & $\begin{array}{l}\text { Fearing that China is on the brink } \\
\text { of partition because of increas- } \\
\text { ing foreign pressure, with powers } \\
\text { carving out spheres of influence } \\
\text { on Chinese territory, and the in- } \\
\text { evitable defeat in war with Japan, } \\
\text { The Emperor Guangxu initiates } \\
\text { a number of radical reforms as a } \\
\text { solution to the worsening condi- } \\
\text { tions of his dynasty. The refom- } \\
\text { rms include a total restructuring } \\
\text { of government and the creation } \\
\text { of a cabinet, a national assembly } \\
\text { and a constitution. This leads the } \\
\text { conservatives in the court to rally } \\
\text { around the Empress Cixi. On } 21 \\
\text { September } 1898 \text { the Emperor is } \\
\text { detained and Cixi immediately re- } \\
\text { stores herself as de facto ruler. }\end{array}$ & 1 & 1 & $\begin{array}{l}\text { Cixi resumes the re- } \\
\text { gency, after having } \\
\text { nominally retired in } \\
1889 \text {. She is brought } \\
\text { back in power in a } \\
\text { coup orchestrated by } \\
\text { the Qing court's old } \\
\text { order. }\end{array}$ & $\begin{array}{l}\text { Dillon (2010: } \\
\text { 115-117); Britan- } \\
\text { nica }\end{array}$ \\
\hline
\end{tabular}




\begin{tabular}{|c|c|c|c|c|c|c|c|c|c|c|}
\hline $\begin{array}{l}\text { Country } \\
\text { name }\end{array}$ & $\begin{array}{l}\text { V-Dem } \\
\text { code }\end{array}$ & $\begin{array}{l}\text { Regime } \\
\text { name }\end{array}$ & v3regstartdate & & v3regenddate & Notes to v3regenddate & $\begin{array}{l}\text { v3regend- } \\
\text { typeMS }\end{array}$ & $\begin{array}{l}\text { v3regend- } \\
\text { type }\end{array}$ & Notes to v3regendtype & Sources \\
\hline China & 110 & $\begin{array}{l}\text { Qing Dy- } \\
\text { nasty/ } \\
\text { de-facto rule } \\
\text { of Empress } \\
\text { Cixi }\end{array}$ & $21 / 09 / 1898$ & 0 & $14 / 08 / 1900$ & $\begin{array}{l}\text { In reaction to what they see as } \\
\text { a menace of Western influence } \\
\text { in China, militia units known as } \\
\text { the boxers, move away from its } \\
\text { anti-Qing traditions and trans- } \\
\text { fer their allegiance to the court } \\
\text { in a struggle against foreigners. } \\
\text { Large numbers of people convert } \\
\text { to the Boxer cause. Initially, } \\
\text { the court attempts at a neutral } \\
\text { stance, but soon finds itself sup- } \\
\text { porting the rebellion. Cixi de- } \\
\text { cided to take part in the hostil- } \\
\text { ities by ordering troops to join } \\
\text { the uprising. Foreign legations in } \\
\text { Beijing are under siege for eight } \\
\text { weeks. Foreign powers gather a } \\
20 \text { o00 strong force that captures } \\
\text { Beijing } 14 \text { August } 1900 \text {. Russia } \\
\text { uses the Boxer rebellion as pretext } \\
\text { to invade Manchuria. }\end{array}$ & 6 & 6 & $\begin{array}{l}\text { Defeat in interstate } \\
\text { war }\end{array}$ & $\begin{array}{l}\text { Dillon (2010: } \\
\text { 121-130); Britan- } \\
\text { nica }\end{array}$ \\
\hline China & 110 & $\begin{array}{l}\text { Eight Nation } \\
\text { Alliance } \\
\text { occupation }\end{array}$ & $14 / 08 / 1900$ & 0 & 07/09/1901 & $\begin{array}{l}\text { It takes a year to get a treaty } \\
\text { ready to be signed. The one-sided } \\
\text { content of the Boxer Protocol is } \\
\text { a humiliation for the Qing court } \\
\text { inflicting severe punishments on } \\
\text { Chinese officials. Cixi agrees to } \\
\text { the terms after being assured of } \\
\text { her continued reign. The for- } \\
\text { eign governments agree to with- } \\
\text { draw their troops apart from lega- } \\
\text { tion guards. }\end{array}$ & 10 & 10 & $\begin{array}{l}\text { Considered an } \\
\text { intended transfor- } \\
\text { mational process } \\
\text { dictated by the } \\
\text { foreign powers. } \\
\text { The United States, } \\
\text { part of the eight } \\
\text { nation alliance, } \\
\text { prevents a partition } \\
\text { of China in the } \\
\text { protocol insisting } \\
\text { on the preservation } \\
\text { of China's territo- } \\
\text { rial integrity. The } \\
\text { foreign powers are } \\
\text { given the rights to } \\
\text { occupy } 12 \text { towns } \\
\text { along the coast to } \\
\text { give them access to } \\
\text { the sea. }\end{array}$ & $\begin{array}{l}\text { Dillon (2010: } \\
\text { 126-131); Britan- } \\
\text { nica }\end{array}$ \\
\hline
\end{tabular}




\begin{tabular}{|c|c|c|c|c|c|c|c|c|c|c|}
\hline $\begin{array}{l}\text { Country } \\
\text { name }\end{array}$ & $\begin{array}{l}\text { V-Dem } \\
\text { code }\end{array}$ & $\begin{array}{l}\text { Regime } \\
\text { name }\end{array}$ & v3regstartdate & & v3regenddate & Notes to v3regenddate & $\begin{array}{l}\text { v3regend- } \\
\text { typeMS }\end{array}$ & $\begin{array}{l}\text { v3regend- } \\
\text { type }\end{array}$ & Notes to v3regendtype & Sources \\
\hline China & 110 & $\begin{array}{l}\text { Qing Dy- } \\
\text { nasty/ } \\
\text { de-facto rule } \\
\text { of Empress } \\
\text { Cixi }\end{array}$ & 07/09/1901 & 0 & 01/01/1912 & $\begin{array}{l}\text { On } 14 \text { November } 1908 \text { Emperor } \\
\text { Guangxu suddenly dies at the age } \\
\text { of } 37 \text {. The Empress dies the day } \\
\text { after. The Emperor is succeeded } \\
\text { by Puyi (the Xuantong Emperor), } \\
\text { the son of Prince Chun. Chun } \\
\text { is nominal but ineffectual regent } \\
\text { during the reign of the infant Em- } \\
\text { peror. Court policy remains in } \\
\text { the hands of court officials who } \\
\text { continue to attempt to modernize } \\
\text { government until the Revolution } \\
\text { of } 1911 \text {. The Xinhai revolution } \\
\text { overthrows the Qing Dynasty. }\end{array}$ & 8 & 8 & $\begin{array}{l}\text { Initially sparked by } \\
\text { an army mutiny in } \\
\text { Wuhan urged on } \\
\text { by revolutionaries } \\
\text { and the province } \\
\text { secession from the } \\
\text { Empire triggers a } \\
\text { chain reaction in } \\
\text { which province after } \\
\text { province declares } \\
\text { their independence } \\
\text { from the Qing court. }\end{array}$ & $\begin{array}{l}\text { Dillon (2010: } \\
\text { 135-139, 143, } \\
\text { 145-146); Britan- } \\
\text { nica }\end{array}$ \\
\hline China & 110 & $\begin{array}{l}\text { Provisional } \\
\text { presidency of } \\
\text { Sun Yat-sen }\end{array}$ & $01 / 01 / 1912$ & 0 & $10 / 03 / 1912$ & $\begin{array}{l}\text { Meanwhile, Yuan Shikai, who at } \\
\text { the time is prime minister at the } \\
\text { court, and his troops demands the } \\
\text { abdication of the emperor. On } \\
12 \text { February the Emperor abdi- } \\
\text { cates. The day after Yuan Shikai } \\
\text { declares his support for the Re- } \\
\text { public. The samy day Sun Yat- } \\
\text { sen expresses his willingness to } \\
\text { step down as president in favor } \\
\text { of Shikai. Shikai is formally in- } \\
\text { ducted into office } 10 \text { March. }\end{array}$ & $10,8,1$ & 10 & $\begin{array}{l}\text { Transformational } \\
\text { process by sitting } \\
\text { regime }\end{array}$ & $\begin{array}{l}\text { Dillon (2010: } \\
\text { 145-147); Britan- } \\
\text { nica }\end{array}$ \\
\hline
\end{tabular}




\begin{tabular}{|c|c|c|c|c|c|c|c|c|c|c|}
\hline $\begin{array}{l}\text { Country } \\
\text { name }\end{array}$ & $\begin{array}{l}\text { V-Dem } \\
\text { code }\end{array}$ & $\begin{array}{l}\text { Regime } \\
\text { name }\end{array}$ & v3regstartdate & & v3regenddate & Notes to v3regenddate & $\begin{array}{l}\text { v3regend- } \\
\text { typeMS }\end{array}$ & $\begin{array}{l}\text { v3regend- } \\
\text { type }\end{array}$ & Notes to v3regendtype & Sources \\
\hline China & 110 & $\begin{array}{l}\text { Provisional } \\
\text { Constitu- } \\
\text { tion of the } \\
\text { Republic } \\
\text { of China/ } \\
\text { Provisional } \\
\text { Presidency } \\
\text { of Yuan } \\
\text { Shikai }\end{array}$ & 10/03/1912 & 0 & $15 / 12 / 1913$ & $\begin{array}{l}\text { Song Jiaoren, leader of the Guo- } \\
\text { mindang, at the moment the } \\
\text { largest political coalition in the } \\
\text { new Parliament works to bring } \\
\text { Guomindang to power through } \\
\text { constitutional mechanisms estab- } \\
\text { lished under the provisional con- } \\
\text { stitution. After winning elec- } \\
\text { tions, Jiaoren works for the cab- } \\
\text { inet to be brought under control } \\
\text { of the majority party. Jiaoren } \\
\text { is shortly in early } 1913 \text { found } \\
\text { dead at the Shanghai railway sta- } \\
\text { tion. In June Yuan Shikai dis- } \\
\text { misses provincial governors who } \\
\text { had supported Guomindang in the } \\
\text { elections. A deposed governor de- } \\
\text { clares war on Yuan. The revolt } \\
\text { is supressed and Yuan orders that } \\
\text { all representatives of Guomindang } \\
\text { in the provincial assemblies be } \\
\text { dismissed. On } 15 \text { December the } \\
\text { National Assembly is replaced by } \\
\text { a Political Conference completely } \\
\text { under his control. }\end{array}$ & 2 & 2 & $\begin{array}{l}\text { Considered a self- } \\
\text { coup by the sitting } \\
\text { leader Yuan Shikai. }\end{array}$ & $\begin{array}{l}\text { Dillon (2010: } \\
\text { 146-152); Britan- } \\
\text { nica }\end{array}$ \\
\hline China & 110 & $\begin{array}{l}\text { Authoritar- } \\
\text { ian Regime } \\
\text { of Yuan } \\
\text { Shikai }\end{array}$ & $15 / 12 / 1913$ & 0 & $06 / 06 / 1916$ & $\begin{array}{l}\text { Having initially gained popular- } \\
\text { ity for defending China's interests } \\
\text { against Japan's ultimatum that } \\
\text { China should concede key areas of } \\
\text { economic policy and government } \\
\text { to Japan under the Twenty-One } \\
\text { Demands, he becomes highly un- } \\
\text { popular with his attempt to re- } \\
\text { store monarchy. After some of the } \\
\text { southwestern provinces declare in- } \\
\text { dependence from China } 21 \text { May } \\
1916 \text {, he decides to abandon his } \\
\text { plans of restoration of a monar- } \\
\text { chy hoping that this could avert } \\
\text { civil war. The revolt spreads with } \\
\text { military leaders declaring their } \\
\text { provinces independent. Yuan } \\
\text { Shikai dies on } 6 \text { June } 1916 \text {. }\end{array}$ & 4 & 4 & $\begin{array}{l}\text { Several military re- } \\
\text { volts end in decla- } \\
\text { rations of indepen- } \\
\text { dence in province } \\
\text { after province, but } \\
\text { this does not topple } \\
\text { the regime in Bei- } \\
\text { jing, even if they } \\
\text { loose large pieces of } \\
\text { territory. Regime } \\
\text { change in the capital } \\
\text { comes as the result } \\
\text { of the death of Yuan. }\end{array}$ & $\begin{array}{l}\text { Dillon (2010: } \\
\text { 152-159); Britan- } \\
\text { nica }\end{array}$ \\
\hline
\end{tabular}




\begin{tabular}{|c|c|c|c|c|c|c|c|c|c|c|}
\hline $\begin{array}{l}\text { Country } \\
\text { name }\end{array}$ & $\begin{array}{l}\text { V-Dem } \\
\text { code }\end{array}$ & $\begin{array}{l}\text { Regime } \\
\text { name }\end{array}$ & v3regstartdate & & v3regenddate & Notes to v3regenddate & $\begin{array}{l}\text { v3regend- } \\
\text { typeMS }\end{array}$ & $\begin{array}{l}\text { v3regend- } \\
\text { type }\end{array}$ & Notes to v3regendtype & Sources \\
\hline China & 110 & $\begin{array}{l}\text { Beyiang } \\
\text { military rule } \\
\text { under Li } \\
\text { Yuanhong }\end{array}$ & 06/06/1916 & 0 & $14 / 06 / 1917$ & $\begin{array}{l}\text { Duan wants to side with the U.S. } \\
\text { and enter war, but Li refuses, } \\
\text { dismisses Duan and calls General } \\
\text { Zhang Xun, a Qing-loyalist and } \\
\text { Yuan Shikai supporter, to medi- } \\
\text { ate. Zhang demands that Li dis- } \\
\text { solves the Parliament. Right af- } \\
\text { ter, Zhang enters Beijing with his } \\
\text { army and sets about to restore the } \\
\text { Dynasty. }\end{array}$ & 0 & 0 & $\begin{array}{l}\text { Military coup of the } \\
\text { Capital to restore } \\
\text { dynastic rule. }\end{array}$ & $\begin{array}{l}\text { Dillon 2010: } 160- \\
\text { 162); Britannica }\end{array}$ \\
\hline China & 110 & $\begin{array}{l}\text { Zhang Xun's } \\
\text { coup d'état/ } \\
\text { Manchu } \\
\text { Restoration }\end{array}$ & $14 / 06 / 1917$ & 0 & $14 / 07 / 1917$ & $\begin{array}{l}\text { Duan captures Beijing } 14 \text { July. } \\
\text { Duan resumes his role as prime } \\
\text { minister, with Feng Gochang as } \\
\text { acting president. Feng brings his } \\
\text { own army division. }\end{array}$ & 0 & 0 & $\begin{array}{l}\text { Counter coup by } \\
\text { Duan's army to re- } \\
\text { store the Republic. }\end{array}$ & $\begin{array}{l}\text { Dillon (2010: } \\
\text { 160-161) Britan- } \\
\text { nica }\end{array}$ \\
\hline China & 110 & $\begin{array}{l}\text { Beyiang } \\
\text { Military } \\
\text { rule under } \\
\text { Duan's } \\
\text { Anhui Clique }\end{array}$ & $14 / 07 / 1917$ & 0 & $06 / 07 / 1920$ & $\begin{array}{l}\text { On } 4 \text { May } 1919 \text { a mass demon- } \\
\text { stration breaks out in which stu- } \\
\text { dents in Beijing protest against } \\
\text { the terms of the Paris Peace Con- } \\
\text { ference, initiating the May Fourth } \\
\text { Movement. Violence breaks out } \\
\text { in Beijing. The overseas Guomin- } \\
\text { dang endorses the movement. The } \\
\text { government soon complies and re- } \\
\text { fuses to sign the treaty. But the } \\
\text { Anhui clique's power is deteriorat- } \\
\text { ing, and the Feng's faction, the } \\
\text { Zhili Clique takes advantage of } \\
\text { the situation. War breaks out in } \\
\text { Beijing between the two military } \\
\text { factions of Beyiang in July } 1920 \text {, } \\
\text { ending Anhui domination in gov- } \\
\text { ernment. }\end{array}$ & 8,5 & 5 & civil war & $\begin{array}{l}\text { Dillon (2010: } \\
\text { 160-162, 175- } \\
\text { 178); Britannica }\end{array}$ \\
\hline China & 110 & $\begin{array}{l}\text { Interreg- } \\
\text { num China } \\
1 / \text { Era of } \\
\text { Warlords- } \\
\text { post- } \\
\text { July1920 }\end{array}$ & $06 / 07 / 1920$ & 0 & $10 / 10 / 1928$ & $\begin{array}{l}\text { The National Revolutionary Army } \\
\text { captures Beijing on } 6 \text { June } 1928 . \\
\text { On October } 10 \text { a National Govern- } \\
\text { ment of the Republic of China is } \\
\text { established, the first to be able to } \\
\text { do so with justification since the } \\
\text { death of Yuan Shikai. The Guo- } \\
\text { mindang government in power is } \\
\text { accepted by most of the south and } \\
\text { most of the north. }\end{array}$ & 5 & 5 & Loss in civil war & $\begin{array}{l}\text { Dillon (2010: } \\
\text { 158-159, 209- } \\
\text { 212); Britannica }\end{array}$ \\
\hline
\end{tabular}




\begin{tabular}{|c|c|c|c|c|c|c|c|c|c|c|}
\hline $\begin{array}{l}\text { Country } \\
\text { name }\end{array}$ & $\begin{array}{l}\text { V-Dem } \\
\text { code }\end{array}$ & $\begin{array}{l}\text { Regime } \\
\text { name }\end{array}$ & v3regstartdate & & v3regenddate & Notes to v3regenddate & $\begin{array}{l}\text { v3regend- } \\
\text { typeMS }\end{array}$ & $\begin{array}{l}\text { v3regend- } \\
\text { type }\end{array}$ & Notes to v3regendtype & Sources \\
\hline China & 110 & $\begin{array}{l}\text { Nationalist } \\
\text { government } \\
\text { in Nanjing }\end{array}$ & $10 / 10 / 1928$ & 0 & $13 / 12 / 1937$ & $\begin{array}{l}\text { Throughout the next decade, the } \\
\text { Nationalists struggle with frag- } \\
\text { mentation and the growing CCP } \\
\text { in the west. When the Sino- } \\
\text { Japanese war begins, the nation- } \\
\text { alists and CCP decide agree to } \\
\text { form a united front against Japan. } \\
\text { On Dec } 13 \text {, japanese froces cap- } \\
\text { ture the capital Nanjing. }\end{array}$ & 6 & 6 & $\begin{array}{l}\text { Loss in inter-state } \\
\text { war with Japan }\end{array}$ & $\begin{array}{l}\text { Dillon (2010: } \\
\text { 158-159, 209- } \\
\text { 212), Britannica, } \\
\text { Brecher and } \\
\text { Wilkenfeld } \\
(1997: 157)\end{array}$ \\
\hline China & 110 & $\begin{array}{l}\text { Japanese } \\
\text { occupation } \\
\text { of Nanjing/ } \\
\text { interregnum/ } \\
\text { rivalling } \\
\text { between } \\
\text { Chinese and } \\
\text { Japanese } \\
\text { control }\end{array}$ & $13 / 12 / 1937$ & 0 & $15 / 08 / 1945$ & $\begin{array}{l}\text { The Pacific War ended on Aug } 15 \\
1945 \text { with formal Japanese surren- } \\
\text { der submitted on September } 2 .\end{array}$ & 6 & 6 & $\begin{array}{l}\text { Loss in inter-state } \\
\text { war }\end{array}$ & $\begin{array}{l}\text { Britannica, } \\
\text { Brecher and } \\
\text { Wilkenfeld } \\
(1997: 157), \\
\text { Heazle and } \\
\text { Knight (2007:94) }\end{array}$ \\
\hline China & 110 & $\begin{array}{l}\text { Interreg- } \\
\text { num/ NRA- } \\
\text { PLA civil } \\
\text { war }\end{array}$ & $15 / 08 / 1945$ & & $01 / 10 / 1949$ & $\begin{array}{l}\text { After over three years of war be- } \\
\text { tween Nationalist and Commu- } \\
\text { nist forces, PLA finally controlled } \\
\text { most of the mainland and Chair- } \\
\text { man Mao proclaimed the estab- } \\
\text { lishment of the People's Republic } \\
\text { of China }\end{array}$ & 5,8 & 5 & $\begin{array}{l}\text { Civil war loss for } \\
\text { PLA's enemies and a } \\
\text { popularly based rev- } \\
\text { olution (Britannica). } \\
\text { Civil war deemed } \\
\text { most decisive factor. }\end{array}$ & $\begin{array}{l}\text { Britannica, } \\
\text { Heazle and } \\
\text { Knight (2007:94), } \\
\text { Gao (2009: 363) }\end{array}$ \\
\hline China & 110 & $\begin{array}{l}\text { People's } \\
\text { Republic of } \\
\text { China }\end{array}$ & $01 / 10 / 1949$ & & $\mathrm{E}$ & & & & & $\begin{array}{l}\text { Britannica, Gao } \\
\text { (2009: 363) }\end{array}$ \\
\hline
\end{tabular}




\section{A note on the coding of interregnum}

HRD includes a dichotomous variable to capture interregnum periods (v3interreg), as listed in Appendix A. In HRD, interregnum is not coded as a way of "filling in" for complicated gradual changes (in contrast to the widely used Polity2 measure from Marshall, Gurr and Jaggers, 2013), such as the case of early-1920s Italy discussed in the paper. Rather an interregnum period is coded for situations where no governing elite or body is in place to effectively control/determines policies in major parts of the Polity.

One example is the three month-period that followed in Wallachia (now Romania) in 1848 after a group of revolutionaries forced the sitting Prince Bibescu to support the revolutionary program and name a provisional government. Two days later, the Prince abdicated because of increasing threats, and the Russian consul, responsible for the then-operating Russian Protectorate of Wallachia, left Bucharest. During the following three months, no attempt at consolidating rule was successful (Oetea, 1970; Treptow, 1996). The interregnum period of Wallachia ended when the Ottoman Porte invaded on September 25th 1848.

Another example is the two year-civil war that ravaged Egypt between 1803 and 1805 . After Ottoman occupation in March 1803, Albanian forces under Tahir Pasha assumed government in May. When Pasha was assassinated in June that year, however, the area spiraled into civil war. When power was eventually consolidated, the subsequent regime of Mohammed Ali lasted for a total of 61 years.

Our coders were instructed to be conservative with applying the interregnum coding. One key note in this regard is that the common denominator for most interregnum periods is civil war. However, we also note that there are numerous instances of civil war where the country is still assigned a regime (i.e., scored as 0 on the interregnum dummy), for example territorial civil wars located in particular regions in the periphery but where a government still clearly controls power for most of the territory. 


\section{E Common types of events that are candidates for regime change}

Table A-4 gives an overview of the kinds of events that trigger regime change codings in HRD. For each type of event, we also give a very short description of how we delineate the threshold for whether or not a regime breakdown is coded. First and foremost, the latter thresholds describe when events are deemed to introduce a substantial change to the formal or informal rules that determine how leaders are selected and maintained (and, as such, clarifies the operational boundaries of our definition of regime change). Because of the empirical complexity of the different cases, and our aim to be flexible when coding each individual case, this list is far from exhaustive. ${ }^{1}$ However, the list displays the most common rules-of-thumb applied consistently in the coding.

\footnotetext{
${ }^{1}$ If a case does not fit our scheme, we allow it to be coded as "other" rather than shoehorning it into our pre-defined categorization.
} 


\begin{tabular}{ll}
\hline Regime change event & Description \\
\hline Head executive term extensions & Extension of presidential term limits is coded as regime change in HRD when \\
& this represents a clear move towards consolidating power by the sitting regime. \\
& Abolition of presidential term limits is always coded as regime change, if \\
& the sitting regime is not already a full-fledged and legislatively consolidated \\
& autocracy. They are coded with end type 2 - self-coup.
\end{tabular}

Other autocratic legislation

Suffrage extensions

Other democratizing legislation

Independence

Restructuring legislative action

Relatively free and fair elections

Fraudulent elections

Wars

Effective coups
Legislative action such as changes to the constitution that do not concern the durability of the head executive office can also be coded regime change. This happens in instances where, e.g., severe restrictions are laid on the opposition, or one-party domination of the legislative branch is formalized. These instances are coded end type 2 - self-coup.

Suffrage extensions are coded as regime change when they concern large shares of the population and if, and only if, the extension occurs in regimes where the formal rules correspond with the informal rules. These are coded end type 9 - guided liberalization.

Regime change is coded for instances such as formalization of democratic rights or promulgation of democratic institutions when these mark substantial departures from less democratic forms of government. They are coded if, and only if, they result in regimes where the formal rules correspond with the informal rules. These are coded end type 9 - guided liberalization.

When polities that have had limited autonomy transfer into independence, this is coded as regime change when the previous non-independent entity still enjoyed a good deal of autonomy and their polities worked differently than its sovereign entity. 2 If the transition is made by creating a democratic constitution that is subsequently adhered to de facto, this is coded end type 9 - guided liberalization. If it does not have democratic qualities it is coded end type 10 - directed transition.

Legislative action by the sitting regime that is not related to outright democratization or autocratization is coded regime change when they alter the core make-up of the regime such as transitioning from a parliamentary to a presidential system, or transitioning out of transitional regimes into regimes that are no more or less democratic than the previous, e.g. after coups or civil wars. These are coded end type 10 - directed transition.

Free and fair elections are coded as regime change when held in regimes where this is not the norm, and where the results of the elections are adhered to. These are coded end type 9 - guided liberalization when the elections are part of a greater development by the state to liberalize. When they are not, they are coded end type 11 - liberalization without guidance of sitting regime.

Elections in which substantial reports of vote fraud are given, are coded as regime change when they appear in regimes which have otherwise held elections that are free and fair. Reports of vote buying do not suffice, there must also be deliberate obstructions of the right to a free vote or apparent tampering with election results. These instances are coded end type 2 - self-coup.

Inter- and intra-state wars are recorded as regime change when they efficiently either expel the sitting government or almost totally obstructs its ability to exert power. We code by emphasizing capitol rule - even when substantial areas of the country is beyond governmental control, the sitting regime continues as long as it has control over the capitol. These have their own end type 5 - civil war and 6 - inter-state war.

Describe different kinds of coups and coup settings?

Table A-4: Table of regime changing events (non-exhaustive) 


\section{F Formal and informal rule changes and regime change}

In the paper, we discussed at length how we consider the relevance of formal and informal rules for selecting and maintaining leaders when defining regimes, and how substantial changes to both formal and informal rules - in different circumstances - may trigger regime change. For instance, a constitutional democratic regime may end through changes in its formal rules (through substantial liberalization, e.g. introduction of universal suffrage, or through non-liberalizing legislative action, e.g. changing from parliamentarism to strong versions of presidentialism), or through changes to its informal rules (e.g., substantial manipulations of elections that allow incumbents to retain office). In the paper, we also discuss some key issues pertaining to when formal rules are used for identifying the regime (when formal and informal rules correspond, broadly speaking) as well as how we may consider the identity of the actors supporting the regime as operational heuristics in cases where informal rules define the regime. In this section, we present some considerations and important rules-of-thumb that complement this discussion.

The thresholds applied for considering changes in formal or informal rules to be understood as substantial (in widely varying real-world scenarios) must, in an application concerned with de facto rather than de jure changes, inevitably be related to subjective judgements. Very reasonable arguments can certainly be made to move the threshold both in a more restrictive and in a more lenient direction, for different types of scenarios. (As mentioned, our thresholds for coding regime changes are typically lower than those applied in the most comparable extant dataset, Geddes, Wright and Frantz (2014).) However, we have applied thresholds that we, after much thinking and some revisions after trial coding of particular cases, find to be the most sensible. Discussions of the sensibility of the particular locations of thresholds aside, one clear advantage with our approach is the emphasis we have placed on internal consistency in the coding, aiming to employ similar thresholds for similar types of scenarios across countries and time, better enabling cross-country and inter-temporal comparisons.

Table A-6 clarifies the instances in which formal and informal rules are used as foundations for regime coding, listed for each category of the regime end type variable. For each of these categories, we present typical examples of situations that would be considered a substantial change in formal or informal rules, leading to the coding of regime breakdown. 


\begin{tabular}{|c|c|c|}
\hline End type & Informal rules emphasized & Formal rules emphasized \\
\hline Military coups & $\begin{array}{l}\text { Military coups are always expressions } \\
\text { of altered informal rules for selecting } \\
\text { leaders }\end{array}$ & None \\
\hline Coups & $\begin{array}{l}\text { Very often expressions of altered infor- } \\
\text { mal rules for selecting leaders }\end{array}$ & $\begin{array}{l}\text { Can in rare instances focus on formal } \\
\text { rules as in electoral coups }\end{array}$ \\
\hline Self-coups & $\begin{array}{l}\text { Self-coups are, by definition, actions } \\
\text { driven by any given regime's incum- } \\
\text { bent to consolidate power. This can } \\
\text { be achieved through changes to infor- } \\
\text { mal rules, e.g. through expulsion of } \\
\text { coalition partners or removal of credi- } \\
\text { ble opposition. }\end{array}$ & $\begin{array}{l}\text { Can also be achieved by changing for- } \\
\text { mal rules, e.g. through constitutional } \\
\text { changes that diminish the role of the } \\
\text { legislature or removal of restrictions on } \\
\text { presidential term-limits. }\end{array}$ \\
\hline Assassination & $\begin{array}{l}\text { Always expressions of informal rules } \\
\text { changing as the leader must be domi- } \\
\text { nant for the regime to change as a con- } \\
\text { sequence of assassination }\end{array}$ & None \\
\hline Natural death & $\begin{array}{l}\text { Always expressions of informal rules } \\
\text { changing as the leader must be domi- } \\
\text { nant for the regime to change as a con- } \\
\text { sequence of natural death. Deaths of } \\
\text { monarchs in formal hereditary monar- } \\
\text { chies will not constitute regime change } \\
\text { (Example: Death of Franco) }\end{array}$ & None \\
\hline Civil war & $\begin{array}{l}\text { Most often informal through change of } \\
\text { leadership (If formal rules in play in } \\
\text { combination, these will be related to } \\
\text { subsequent developments and not to } \\
\text { take-over of power) }\end{array}$ & $\begin{array}{l}\text { In rare instances formal rules are em- } \\
\text { phasized when peace settlements or } \\
\text { similar agreements are made }\end{array}$ \\
\hline Inter-state war & $\begin{array}{l}\text { Most often informal through change of } \\
\text { leadership (If formal rules in play in } \\
\text { combination, these will be related to } \\
\text { subsequent developments and not to } \\
\text { take-over of power) }\end{array}$ & $\begin{array}{l}\text { In rare instances formal rules are em- } \\
\text { phasized when peace settlements or } \\
\text { similar agreements are made }\end{array}$ \\
\hline Foreign intervention & $\begin{array}{l}\text { In some cases concerned with informal } \\
\text { rules because of leadership changes }\end{array}$ & $\begin{array}{l}\text { Can also be focused on formal rules i.e. } \\
\text { through territorial concessions or the } \\
\text { like }\end{array}$ \\
\hline Popular uprising & $\begin{array}{l}\text { Informal rules emphasized when the } \\
\text { consequence of the uprising is leader- } \\
\text { ship removal or step-down }\end{array}$ & $\begin{array}{l}\text { Formal rules emphasized when the } \\
\text { popular pressure has forced legislative } \\
\text { action }\end{array}$ \\
\hline Directed democratization & $\begin{array}{l}\text { Concerned with informal rules if free } \\
\text { and fair elections are held that conjoin } \\
\text { the formal and informal rules }\end{array}$ & $\begin{array}{l}\text { Concerned with formal rules when } \\
\text { democratic institutions, a constitution } \\
\text { or other legislative action is made }\end{array}$ \\
\hline Directed transition & $\begin{array}{l}\text { Concerned with informal rules only to } \\
\text { delineate the extent to which these cor- } \\
\text { respond with formal rules }\end{array}$ & $\begin{array}{l}\text { Most often concerned with formal rules } \\
\text { through incumbent regime legislative } \\
\text { action }\end{array}$ \\
\hline Non-directed democratization & $\begin{array}{l}\text { By definition concerned with informal } \\
\text { rules as the formal rules of the sitting } \\
\text { regime cannot be changed without di- } \\
\text { rection. }\end{array}$ & None \\
\hline
\end{tabular}

Table A-6: Table of formal/informal rules 


\section{G Clarifying and illustrating distinctions between di- rected transitions and self-coups}

As we show in the paper, a substantial number of the regime breakdowns coded in HRD are so-called "directed transitions". In the 14-category scheme for v3regendtype, we distinguish between guided transitions that are accompanied by political liberalization, on the one hand, and all other types of guided transitions. This distinction reflects the importance of eliteled processes of political liberalization historically, but also as a point of focus of theoretical models of regime change (see, e.g., O'Donnell, Schmitter and Whitehead, 1986; Acemoglu and Robinson, 2006). We provide the entire 14-category scheme for v3regendtype in Appendix A, but for the purpose of clarifying and distinguishing between these particular types of regime changes, here is the category wording for the two directed transition categories.

- Substantial political liberalization/democratization with some form of guidance by sitting regime leaders

- Other type of directed and intentional transformational process of the regime under the guidance of sitting regime leaders (excluding political liberalization)

Examples of guided liberalization processes include the type of processes observed, e.g., in Spain after the death of Franco, where democratic institutions were introduced (in a gradual manner) by extant regime elites, but also a number of substantial franchise extensions (often in 19th century polities) are coded as guided liberalization processes. One example is the introduction of the Reform Act in 1832 (March 15) in the United Kingdom, which marks the breakdown of what we have called the Post-Act of Settlement regime extending back to 1701.

Regarding the other directed regime transitions, these include different cases of intentionally guided regime changes pursued by the incumbent regime - excluding those that are related to liberalization processes. One typical case of such a directed transition is illustrated by the transformational process instigated by Charles de Gaulle in France after the Algiers crisis of 1958. Dated to January 8, 1959, when the new constitution came into force, the change led to the end of the parliamentary Fourth Republic, and the beginning of the current semi-presidential Fifth Republic. Other examples of directed transitions include the 1922 Latvian transition into a unicameral parliamentary republic under President Ulmanis, the creation of the Union of South Africa in 1910, the transition into the Pakistani Islamic Republic in 1956, as well as most transitions into partial and/or complete independence for 
former colonies in Africa, Asia and Latin-America. (Exceptions are transitions where substantial uprisings, coups or civil war-like circumstances prompted the end of colonization.)

In addition to the two categories discussed above, v3regendtype includes a separate category for self-coups. In brief, a self-coup (or autogolpe) is a regime transformation involving the incumbent leader, resulting in a substantial consolidation of power in the hands of this leader. In other words, this regime transformation requires the intentional actions and cooperation of at least one key actor of the old regime, namely the chief executive (although other key regime actors are often also involved). The crucial defining feature of this category, however, and which sets it apart from the two guided transformation categories above, is that it represents a substantial concentration of power in the hands of the leader, after the change of the formal or informal rules for leader selection and maintenance has taken place. Since measuring power, and registering increased concentration of power, is inherently difficult, this means that this category is sometimes hard to differentiate from "other directed regime transitions". Let us therefore further elaborate on and illustrate this issue:

Typical examples of self-coups occur with the passing of legislation that clearly tilts the balance of power towards the executive (typically president) and away from the legislative body. In some cases, such as the 1992 Fujimori self-coup in Peru, an event occurs that immediately restricts the choices available to the legislature or opposition in such a way that coding v3regendtype as self-coup stands out as a clear decision. Fujimori was assisted by the military in dissolving Congress, before having a new legislature elected and subsequently a new constitution promulgated (Levitsky, 1999). In other cases, such as the transition to Fascist rule in Italy, as discussed in the paper, coding v3regendtype as a guided transformation or self-coup is more readily debatable. The discussed Acerbo Law was, indeed, passed in the Senate, which based on a de jure approach to coding regime breakdown might indicate that the accompanying regime change did not entail a self-coup. Yet, when taking into account the strong-man tools used by the Fascist groupings, the inherent block on any opposition influence on policy that the Acerbo Law imposed, and the ultimate concentration of power in the hands of Mussolini, v3regendtype is coded as a self-coup. 


\section{H Polity changes and regime changes}

The country-units, or more precisely polity-units - note that several colonies and other nonindependent entities are also treated as separate units - used for the HRD coding, are the careful definitions laid out in V-Dem's country-unit document (v.8; Coppedge et al. 2018). We will not go into the details on how V-Dem delineates polities and determines their time series here, but instead refer interested readers to the noted document for the general rules for defining polities as well as details on exactly which areas are counted, in any given time period, for each polity. To exemplify the latter, we provide an excerpt for a definition of one country (Romania) from the V-Dem country units document (Coppedge et al. 2018, 27):

\section{Romania (190)}

- Coded: 1789-

- History: Principality of Wallachia under Ottoman suzerainty (1789-1861); Austrian occupation (1789-1791); Russian Occupation (1807-1812); direct Ottoman rule (18211822); Russian occupation (1828-1834); incorporates Ottoman rayas north of the Danube (1829); Russian protectorate (1834-1854); Russian occupation (1853-1854); Austrian occupation (1854-1856); personal union with Moldavia (1859-1862); United Romanian Principalities (1862-1866); Romania (1866-1881); cedes three districts in southern Bessarabia to Russia and incorporates northern Dobruja (1878); Kingdom of Romania (1881-1947); annexes southern Dobruja (1913); occupied by Central Powers (1916); Dobruja annexed by Bulgaria (1918); Bessarabia incorporated into Romania (1918); incorporates Dobruja, Bukovina and Transylvania (1919); Soviet occupation (1944-1947); Peoples Republic of Romania (1947-1965); Socialist Republic of Romania (1965-1989); Romania (1989- ).

- Note: Please only code Wallachia between 1789 and 1862. Between 1900 and 1918 includes only pre-World War I territory. Includes Southern Dobruja 1913-1940, Bassarabia 1918-1940 and 1941-1944. Does not include Northern Transylvania 1940-1947. Does not include territories to the East annexed during World War II.

This categorization of polities also defines the time series for which an entity is coded for all relevant $\mathrm{V}$-Dem variables, including the HRD variables. This brings up the question of how to code regime changes - following our definition laid out in the paper, pertaining to 
substantial changes in formal or informal rules on the selection and maintenance of political leaders - in cases where polities merge, are born, disappear, or reappear. We discuss the rules and coding practices of some prominent such cases below, and illustrate them with specific examples.

\section{H.1 When federations/unions form and dissolve}

In cases where two or more polities merge to form a single polity or when an existing polity dissolves, regime changes are coded in many, but not all, instances. In cases where mergers of separate polities into single countries, unions or federations occur - that is, when none of the merging or acquired polities become colonies or receive similar subordinate status - regime changes are always recorded for all polities involved, typically preceded by a regime end that is coded as a "directed transition". Instances of such processes include the formation of the Union of Soviet Socialist Republics in 1922, the formation of the Kingdom of Serbs, Croats and Slovenes (later named the Kingdom of Yugoslavia) in 1918, and the formation of the Ethiopian - Eritrean Federation under Haile Selassie in 1952. These three instances were all results of directed transitions, even though the cooperation between the parties was substantially influenced by the uneven power balance in all three cases.

We may draw on the same polities for illustrating the coding pertaining to when countries dissolve. The dissolution of the USSR in 1991 was a seminal event, with global ripple effects. For many of the 15 now Post-Soviet states, the dissolution led to considerable societal and political upheaval. These instances are recorded as regime change for all polities involved, and the regime end type in most of these cases is coded as liberalization without direction from sitting regime leaders. In contrast, for the dissolution of the EthiopianEritrean Federation in 1991-1993, only Eritrea, which de facto became a separate state in 1991, has this event recorded as regime change. Eritrea's de facto independence, on May 24, came after the advances of the Tigray Peoples Liberation Front (TPLF/EPLF). This date of de facto independence is also registered as the date of regime change for Eritrea. But, May 1991 is a crucial month for Ethiopia as well. In fact, Ethiopia registers a regime change when Mengistu, the regime's strong-man leader since 1974, was forced from power by the Ethiopian People's Revolutionary Democratic Front(EPRDF). This happened on May 28th, which is the recorded date of regime change. These two situations are, of course, inherently interlinked - the fall of Mengistu's regime, and the demise of centralized power of the incumbent regime, was linked to the successes of both the TPLF/EPLF as the EPRDF. Yet, the processes are treated as distinct in our regime coding, with different degrees of 
relevance to each of the two polities, and they are thus not coded as the same regime-change event. $^{3}$

While Ethiopia/Eritrea is a rather special case of a dissolving, contiguous polity in the dataset, a similar logic as that laid out above is applied for the coding of nearly all decolonizing transitions. When a colony breaks away from its former colonizer, this is coded as a regime change in the colony but does typically not constitute a regime change event in the colonizer polity. This is because the de facto rules for selecting and maintaining leaders typically do not experience substantial changes in the colonizer. We turn now to a different issue of regime coding in colonies.

\section{H.2 The relevance of colonizer polity regime changes on the col- onized polity}

When colonies become independent, or achieve limited, but still meaningful autonomy in some way, regime change is, as noted, only coded for the colony. Similarly, regime change is only recorded in the colonized polity when transitions take effect for the local rule of the colony. In other words, regime changes in colonizer countries are only coded as regime changes in the colonized polity if the former clearly lead to de facto changes in the rules of relevance in the colony. This distinction is observed for most French colonies in the 20th century, when Vichy French administrations take over during WWII. For the colonies, the dates do, however, consistently follow the specific developments in the individual countries rather than internal French developments. The French Third Republic ends with the German invasion on July 10th, 1940. In most of French West Africa, the Vichy French government is instated on the same day, but in French Indochina, the change only happens two months later on September 22nd, after Japan interferes. In extension, when the transition from the Fourth to the Fifth Republic took effect in France, this event did not - in itself - imply transitions in the French Colonies. However, most French colonies transitioned into first partial, then full, independence, over the same period. While these regime changes occurring in both France and its colonies can very well be understood as causally interlinked, the transitions in each colony are treated and coded separately.

\footnotetext{
${ }^{3}$ Note that Eritrea is coded as a separate polity in V-Dem from 1900, covering, for example, the colonial era, the federation period and the period after 1962 when it is a constituent part of Ethiopia.
} 


\section{Temporal heterogeneity: Coups and uprisings}

In the paper we estimated a Bayesian Change Point model on the average frequency of all regime breakdowns over time, responding to the question of whether there are likely "structural breaks" in the yearly stability of regimes across modern history. This exercise identified four plausible such change points, namely in 1798 (starting off the first highfrequency period, or wave, of breakdowns), 1881 (starting the first low-frequency, or crest, period), 1913 (starting second wave), and 1995 (starting second crest).

Yet, as our discussion and interpretation of descriptive statistics in the paper made abundantly clear, different modes of breakdowns have followed their own (non-linear) trends across this long time interval. For example, over the last couple of decades, we have seen a decreasing number of regime breakdowns due to coups (especially when compared to the 1960s and 70s), whereas regime breakdowns due to popular uprisings have been on the increase, at least since the late-1990s.

This notion of such different trends, reflecting that different eras may harbor structural conditions that conduce some types of regime changes but are less conducive to others, is further corroborated when we employ the same Change Point set-up to regime changes stemming (only) from particular modes of breakdown. For instance, we do not obtain similar - or even close to similar - timing of the estimated change points, when we analyze coups (by the military and by other actors, combined) and popular uprisings separately.

The results for coups are presented in Figures A-2 and A-3. Without describing or interpreting these results in too much detail, we simply note that for coups, the change point model detects two change points, namely right after 1960 and right after 1980. These years mark the start and end points of a clear uptick in the frequency of coup-induced transitions globally. As noted in the paper, the 1960s and 70s experienced a large number of coups, globally, and particularly in recently de-colonized states in Sub-Saharan Africa. (We here remind that these polities are typically coded back to 1900, or even further back, as colonies for HRD, and are thus also included in the sample prior to 1960). As we also discuss in the paper, recent work on coups, drawing on post-1960 data, have highlighted the declining trend for coups over the last few decades. What is less appreciated, however, is that the post-1960s period also marked a clear break with previous decades when it comes to coup frequency.

Interestingly, when we run our baseline model employed in the paper on coup-breakdowns for the split samples demarcated by the change point (see Table A-7), an intermediate level of democracy is clearly related to higher coup frequency for all time periods. For the economic 
determinants, however, there are stronger indications of temporal heterogeneity. Notably, neither income level nor short-term growth were related to coups during the long 17891962 period. In contrast, we find that poorer countries were systematically more likely to experience coup breakdowns during the "coup wave" from 1962-1981, whereas during the low-frequency period after 1981 experiencing low short-term growth is clearly associated with increased risk of coup breakdown. These differences should direct our attention to structural factors and omitted variables that trend over time but are not included in the baseline model. 
Figure A-2: Change points for coups, 1789-2014

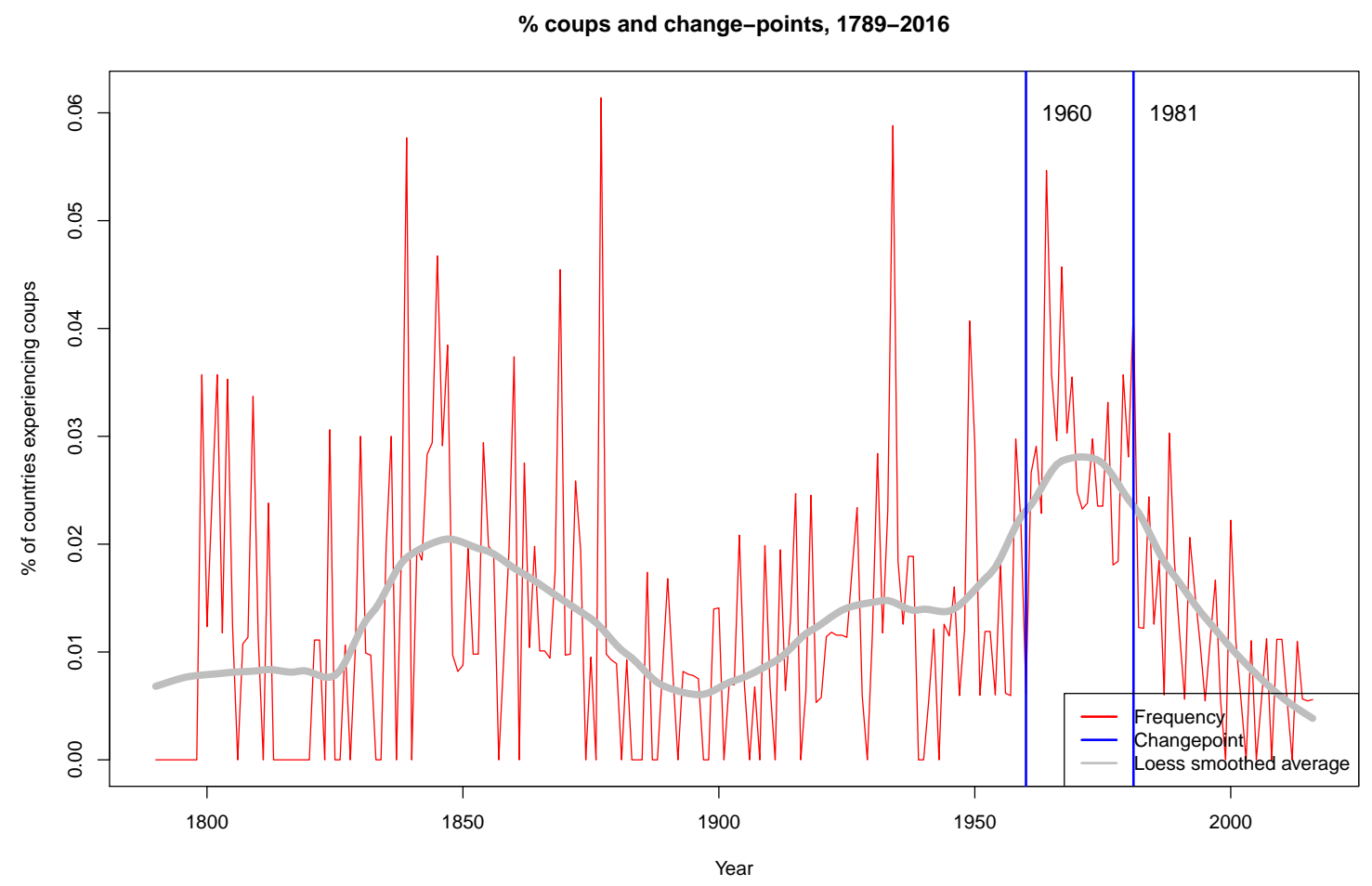

changepoints3.pdf 
Figure A-3: Posterior probabilities of change points for coups, 1789-2014

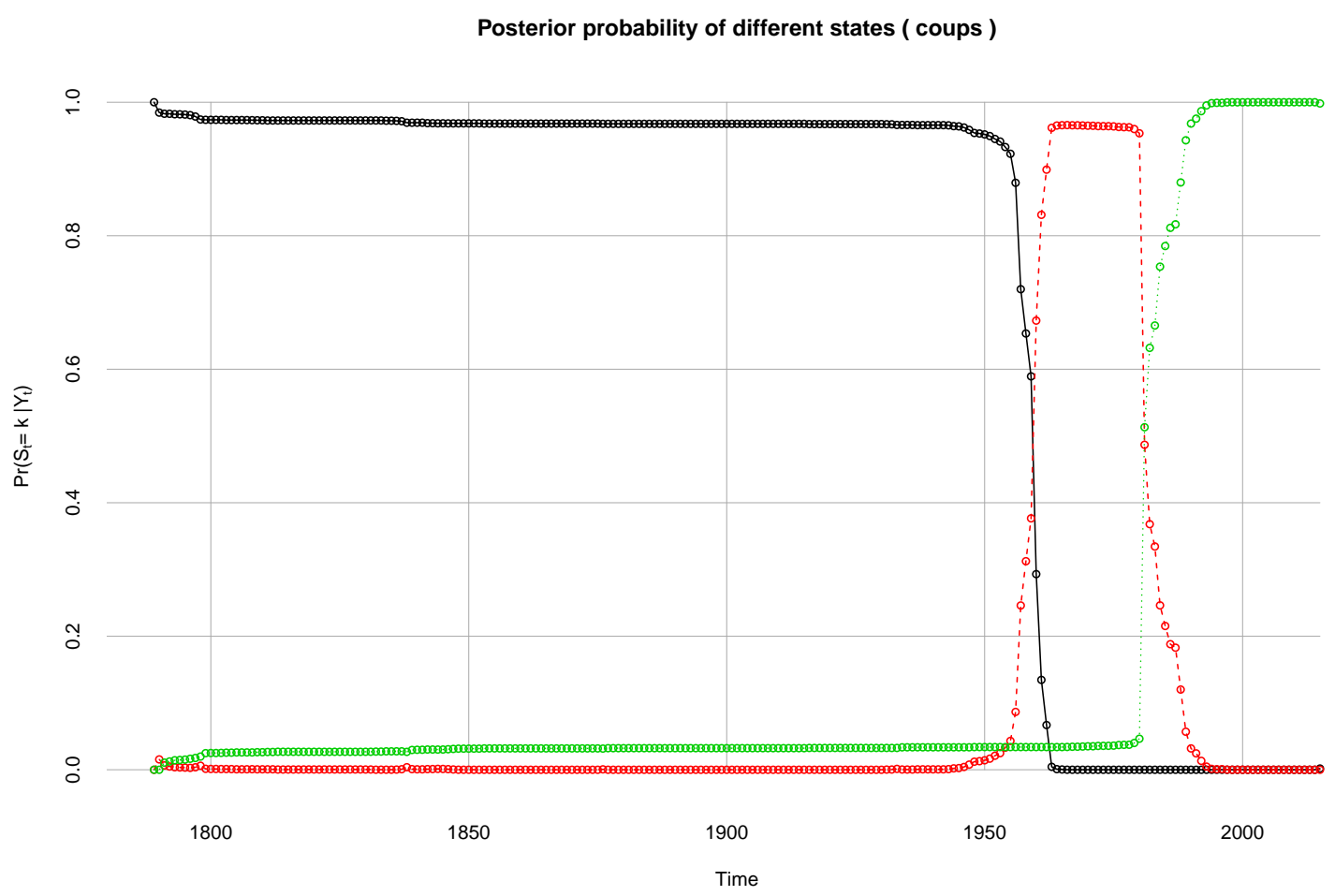

changepoints.pdf 
Table A-7: Logit models on the risk of regime breakdowns due to coups across different periods, as defined by coup-specific change points

\begin{tabular}{lcccc}
\hline & $(\mathrm{A} 1)$ & $(\mathrm{A} 2)$ & $(\mathrm{A} 3)$ & $(\mathrm{A} 4)$ \\
\hline Period: & $1789-2014$ & $1789-1962$ & $1962-1981$ & $1981-2014$ \\
\hline Democracy & $7.308^{* * *}$ & $5.610^{*}$ & $8.566^{* *}$ & $12.337^{* *}$ \\
& $(5.00)$ & $(2.56)$ & $(3.18)$ & $(3.13)$ \\
Democracy $^{2}$ & $-10.566^{* * *}$ & $-10.550^{* *}$ & $-11.201^{* *}$ & $-14.629^{* *}$ \\
& $(-5.36)$ & $(-2.76)$ & $(-3.06)$ & $(-3.16)$ \\
L(GDP p.c.) & -0.212 & -0.021 & $-0.420^{*}$ & -0.390 \\
& $(-1.49)$ & $(-0.11)$ & $(-2.02)$ & $(-1.13)$ \\
L(Population) & 0.003 & 0.025 & $0.181^{*}$ & -0.148 \\
& $(0.05)$ & $(0.34)$ & $(2.03)$ & $(-0.96)$ \\
GDP p.c. growth & $-0.009^{* *}$ & -0.011 & -0.005 & $-0.030^{* *}$ \\
& $(-2.82)$ & $(-1.25)$ & $(-1.17)$ & $(-3.20)$ \\
\hline Region-FE & $\checkmark$ & $\checkmark$ & $\checkmark$ & $\checkmark$ \\
Year-FE & $\checkmark$ & $\checkmark$ & $\checkmark$ & $\checkmark$ \\
Duration terms & $\checkmark$ & $\checkmark$ & $\checkmark$ & $\checkmark$ \\
\hline N & 12404 & 5946 & 2472 & 2743 \\
AIC & 2750.379 & 1495.031 & 718.097 & 475.715 \\
ll & -1224.189 & -643.515 & -325.048 & -201.858 \\
\hline \hline
\end{tabular}


The change point model produces quite different results when we zoom in on regime breakdowns due to popular uprisings. While such breakdowns, overall, are less frequent than coup breakdowns, they have experienced some dramatic historical spikes over very limited time intervals, one such spike coming around 1848/9 and another during and right after WWI (see Figure A-4). Right around these spikes, the change point model is unable to yield strong predictions (as captured by the posterior probability densities) about which "state of the world" obtains, when it comes to the risk uprising-induced regime death (see Figure A-5). The model does, however, clearly predict that the pre-1848 state was differently from the state in, say, 1855, and likewise when comparing the years prior to WWI with, say, 1925.

Interestingly, the baseline model run on split samples, reported in Table A-8, provides suggestive evidence that the determinants of popular uprisings may have differed across the different "states" of modern history. Income level is significantly associated with breakdowns due to popular uprisings in the period spanning the two French revolutions of 1789 and 1848, but also during time period from 1917-2014. Note, however, that a higher level of income is positively associated with the outcome in the first period and negatively associated in the last period. Hence, while richer countries were more likely to experience regime deaths due to popular uprisings in the early part of modern history, poor countries are more likely to experience such regime breakdowns after WWI. In this latter period, low short-term economic growth is also associated with regime death due to uprisings, in contrast with the insignificant relationships observed in prior periods. 
Figure A-4: Change points for uprisings, 1789-2014

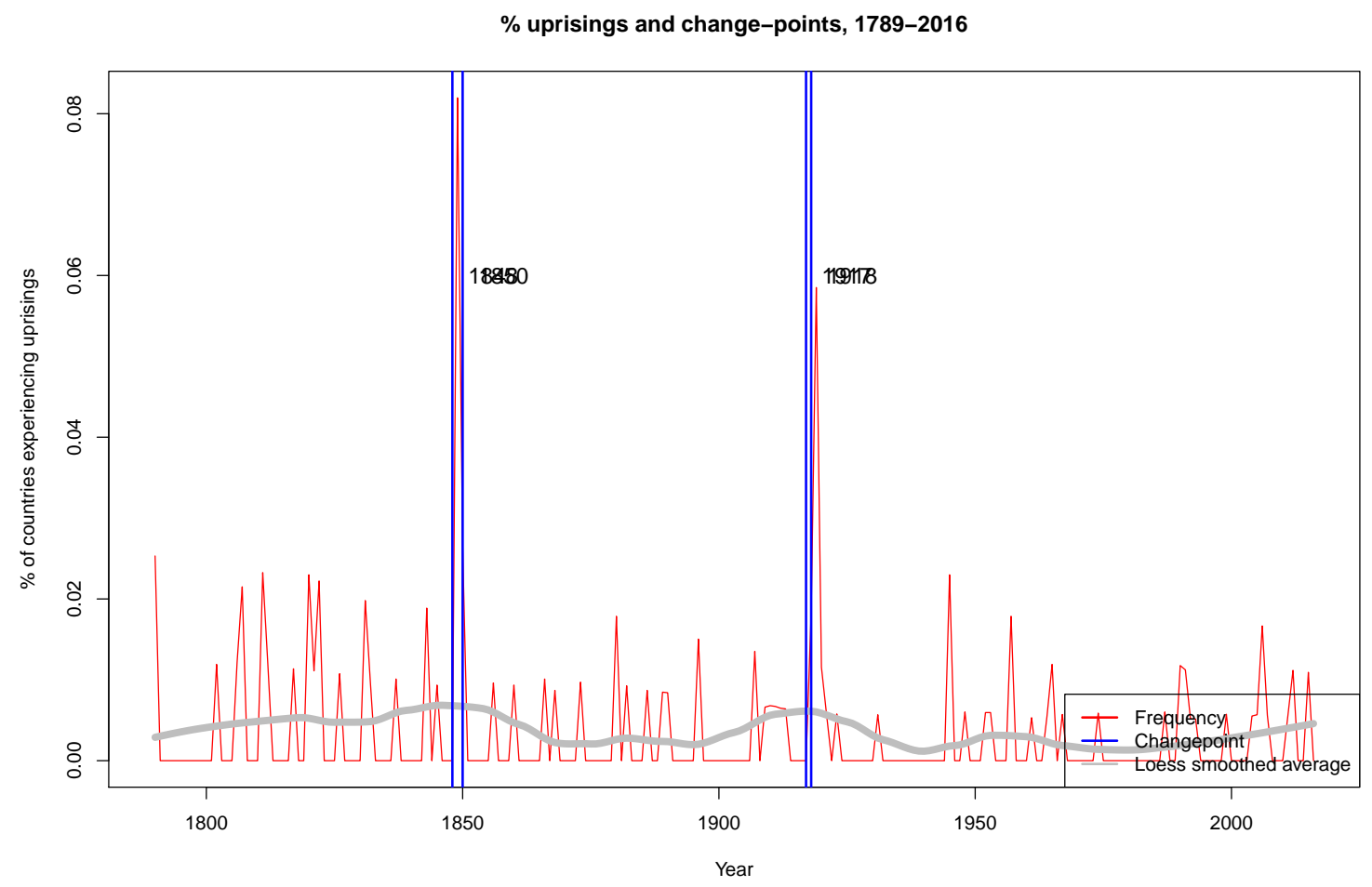

changepoints3.pdf 
Figure A-5: Posterior probabilities of change points for uprisings, 1789-2014

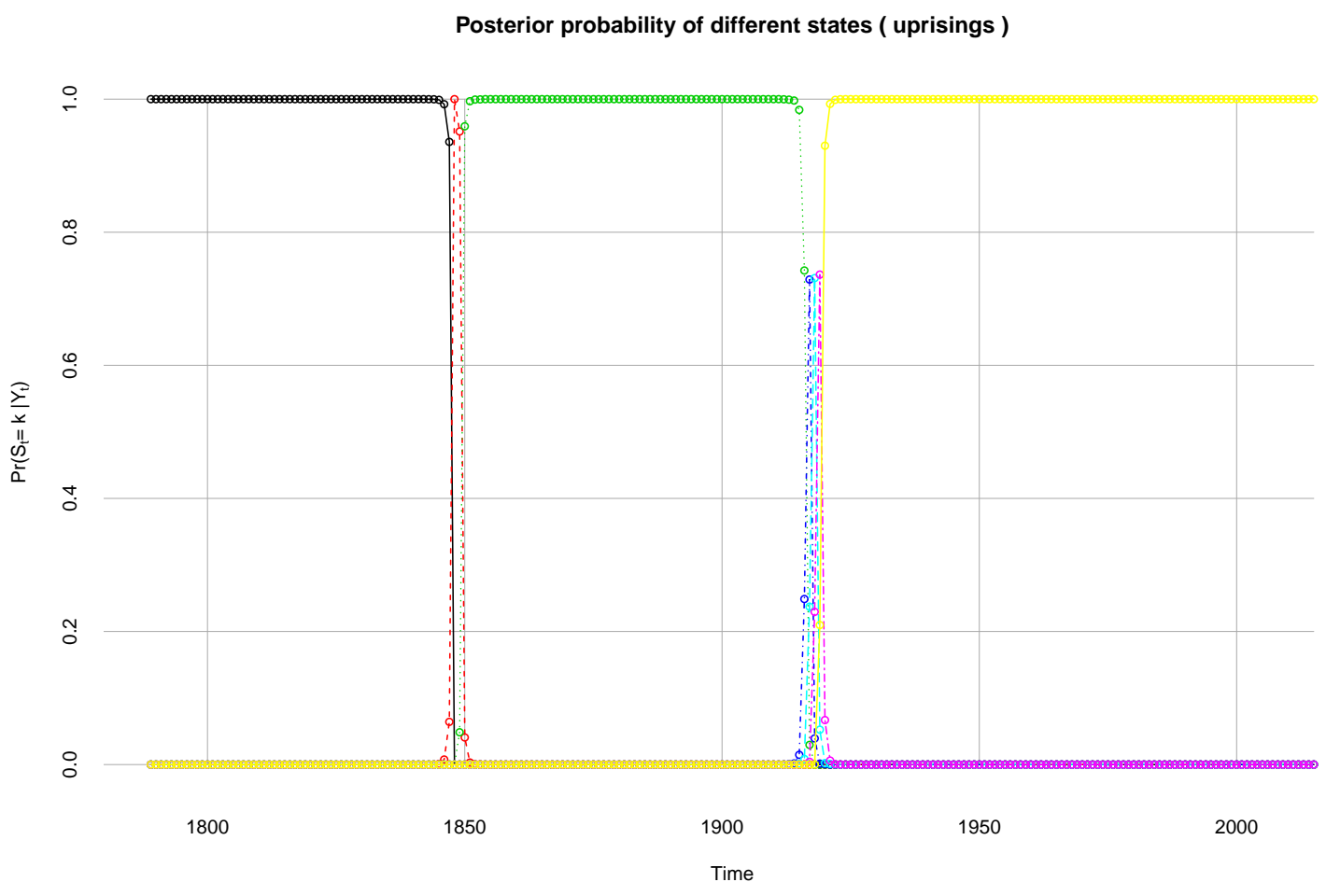

changepoints.pdf 
Table A-8: Logit models on the risk of regime breakdown due to popular uprisings across different time periods, as defined by uprising-specific change points

\begin{tabular}{lcccc}
\hline & $(\mathrm{A} 1)$ & $(\mathrm{A} 2)$ & $(\mathrm{A} 3)$ & $(\mathrm{A} 4)$ \\
\hline Period: & $1789-2014$ & $1789-1848$ & $1848-1917$ & $1917-2014$ \\
\hline Democracy & $7.308^{* * *}$ & $26.901^{*}$ & 6.376 & $10.118^{* * *}$ \\
& $(5.00)$ & $(2.57)$ & $(1.23)$ & $(5.49)$ \\
Democracy $^{2}$ & $-10.566^{* * *}$ & $-68.443^{* *}$ & -20.742 & $-13.480^{* * *}$ \\
& $(-5.36)$ & $(-2.72)$ & $(-1.55)$ & $(-5.65)$ \\
L(GDP p.c.) & -0.212 & $0.737^{*}$ & -0.436 & $-0.404^{*}$ \\
& $(-1.49)$ & $(2.16)$ & $(-1.79)$ & $(-2.41)$ \\
L(Population) & 0.003 & 0.174 & -0.162 & 0.051 \\
& $(0.05)$ & $(1.00)$ & $(-1.05)$ & $(0.73)$ \\
GDP p.c. growth & $-0.009^{* *}$ & 0.034 & 0.013 & $-0.008^{*}$ \\
& $(-2.82)$ & $(0.30)$ & $(0.14)$ & $(-2.30)$ \\
\hline Region-FE & $\checkmark$ & $\checkmark$ & $\checkmark$ & $\checkmark$ \\
Year-FE & $\checkmark$ & $\checkmark$ & $\checkmark$ & $\checkmark$ \\
Duration terms & $\checkmark$ & $\checkmark$ & $\checkmark$ & $\checkmark$ \\
\hline N & 12404 & 586 & 1787 & 9580 \\
AIC & 2750.379 & 271.299 & 550.556 & 1916.650 \\
LL & -1224.189 & -101.649 & -222.278 & -862.325 \\
\hline \hline
\end{tabular}




\section{References}

Acemoglu, Daron and James A. Robinson. 2006. Economic Origins of Dictatorship and Democracy. New York, NY: Cambridge University Press.

Archer, Christon I. and William A. DePalo. 2000. "Discord, Disjunction, and Reveries of Past and Future Glories: Mexico's First Decades of Independence, 1810-1853." Mexican Studies/Estudios Mexicanos 16(1):189-210.

Bazant, Jan. 1977. A Concise History of Mexico. Cambridge: Cambridge University Press.

Beezley, William H and Michael Meyer. 2010. The Oxford History of Mexico. Oxford: Oxford University Press.

Blum, Yehuda Z. 1992. "Russia takes over the Soviet Union's seat at the United Nations." European Journal of International Law 3:354.

Brecher, Michael and Jonathan Wilkenfeld. 1997. A Study of Crisis. Ann Arbor, MI: University of Michigan Press, data available at http://web.missouri.edu/ polsjjh/ICB/.

Conley, Tanja Damljanović. 2013. "The backdrop of Serbian statehoods: morphing faces of the National Assembly in Belgrade." Nationalities Papers 41(1):64-89.

Coppedge, Michael, John Gerring, Carl Henrik Knutsen, Staffan I. Lindberg, Svend-Erik Skaaning, Jan Teorell, Vlad Ciobanu and Moa Olin. 2018. "V-Dem Country Coding Units v8.".

Dillon, Michael. 2010. China: A Modern History. London: IB Tauris.

Freeze, Gregory. 2002. Russia: A History. Oxford: Oxford University Press.

Gao, James Z. 2009. Historical dictionary of modern China (1800-1949). Vol. 25 New York, NY: Scarecrow Press.

Geddes, Barbara, Joseph Wright and Erica Frantz. 2014. "Autocratic Breakdown and Regime Transitions: A New Data Set." Perspectives on Politics 12(2):313-331.

Guedea, Virginia. 2000. "The Process of Mexican Independence." The American Historical Review 105(1):116-130. 
Hamnett, Brian. 1999. A Concise History of Mexico. Cambridge: Cambridge University Press.

Hart, John Mason. 2002. Empire and revolution: The Americans in Mexico since the civil war. Berkeley, CA: University of California Press.

Heazle, Michael and Nick Knight. 2007. China-Japan relations in the twenty-first century: creating a future past? Cheltenham: Edward Elgar Publishing.

Hudson, Rex A. and Dennis M. Hanratty. 1991. Bolivia, a country study. Washington, D.C.: Research Division, Library of Congress.

Krastev, Ivan and Stephen Holmes. 2012. "An autopsy of managed democracy." Journal of Democracy 23(3):33-45.

Lampe, John R. 1996. Yugoslavia as History: There Was Twice a Country. Cambridge: Cambridge University Press.

Levitsky, Steven. 1999. "Fujimori and post-party politics in Peru." Journal of Democracy 10(3):78-92.

Marshall, Monty G., Ted Robert Gurr and Keith Jaggers. 2013. "POLITY IV PROJECT: Political Regime Characteristics and Transitions, 1800-2012." Center for Systemic Peace. Codebook.

Mazower, Mark. 2000. The Balkans. NY: Random House.

Meyer, Michael C and William L Sherman. 1995. The course of Mexican History, 5th ed. New York: Oxford University Press.

Moss, Walter G. 2005. A History of Russia. Vol. 2: To 191\%. London: Wimbledon Publishing Company.

O'Donnell, Guillermo, Philippe Schmitter and Laurence Whitehead. 1986. Transitions from Authoritarian Rule: Tentative Conclusions about Uncertain Democracies (Volume 4). The Johns Hopkins University Press.

Oetea, Andrei. 1970. The history of the Romanian people. Vol. 1 Bucharest: Scientific Pub. Hoose [sic]. 
Riasanovsky, Nicholas and Mark Steinberg. 2011. A History of Russia. Oxford: Oxford University Press.

Schedler, Andreas. 2000. "The Democratic Revelation." Journal of democracy 11(4):5-19.

Stavrianos, Lefteris S. 1963. The Balkans: 1815-1914. New York, NY: Holt, Rinehart and Winston.

Treptow, Kurt W. 1996. A History of Romania. Bucharest: Center for Romanian Studies.

Vanderwood, Paul. 2010. Betterment for whom? The reform period: 1855-75. Oxford: Oxford University Press. 